\title{
Early Cretaceous ribbed aptychi - a proposal for a new systematic classification
}

\author{
LUCIE MĚCHOVÁ, ZDENĚK VAŠíČEK \& †VÁCLAV HOUŠA
}

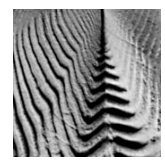

\begin{abstract}
The older system for classification of ribbed calcareous Early Cretaceous aptychi consisted of two genera: Punctaptychus and Lamellaptychus. Later, I. Turculet divided Lamellaptychus into several subgenera. Within the framework of both the genera, species and subspecies were distinguished, which resulted in binominal and trinominal nomenclature. With regard to the richness of newly described species and subspecies in recent years, is not possible to continue using the original system. It is the basic ribbing that plays the decisive role in the generic and subgeneric classification of ribbed aptychi. In the case of subspecies systematics, all details on the valve surface are used with the exception of the sigmoidal bend (fractocostatus) and radial lines (radiatus). The ribbed aptychi are newly divided into the following families: Punctaptychidae fam. nov. and Lamellaptychidae fam. nov. Within the family Punctaptychidae we are able to distinguish two genera: Punctaptychus Trauth, 1927 and Cinctpunctaptychus gen. nov. The family Lamellaptychidae includes five genera differing in the basic arrangement of the ribs: Lamellaptychus Trauth, 1927, Beyrichilamellaptychus Turculet, 1994, Mortilletilamellaptychus gen. nov., Thorolamellaptychus Turculet, 1994 and Didayilamellaptychus Turculet, 1994. Eight species and one subspecies are established as new: Cinctpunctaptychus undulatus, Beyrichilamellaptychus pseudostuderi, Mortilletilamellaptychus mortilletioides, M. submortilleti noricus, M. stanislavi, Didayilamellaptychus hennigi, D. andrusovi and D. renzi. $\bullet$ Key words: Late Jurassic, J/K boundary, Early Cretaceous, aptychi, taxonomy, new taxa.
\end{abstract}

MĚCHOVÁ, L., VAŠíčEK, Z. \& HOUŠA, V. 2010. Early Cretaceous ribbed aptychi - a proposal for a new systematic classification. Bulletin of Geosciences 85(2), 219-274 (11 figures, 2 tables). Czech Geological Survey, Prague. ISSN 1214-1119. Manuscript received August 17, 2009; accepted in revised form February 1, 2010; published online April 16, 2010; June 30, 2010.

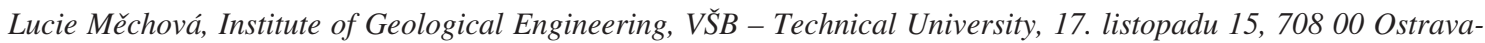
Poruba, Czech Republic; lucie.mechova@vsb.cz・Zdeněk Vašǐček (corresponding author), Institute of Geonics of Academy of Sciences of the Czech Republic, Studentská 1768, 70800 Ostrava-Poruba, Czech Republic; zdenek.vasicek@ugn.cas.cz

Aptychi are a specific group of fossils that usually represent the isolated solid parts of extinct cephalopods belonging to the order Ammonitida Agassiz, 1847. The mentioned elements, at first considered to be operculae, later parts of the jaw apparatus or elements fulfilling both these functions, are not directly any part of ammonite shells. Apart from negligible exceptions, it is not possible to classify aptychi according to the described species and genera of ammonites, which are classified according to the principles of natural systematics, an original, independent classification was created for them in the first half of the $19^{\text {th }}$ century (Trauth 1927-1938).

Since they were first discovered, when the questions as to what aptychi actually were and to which organisms they belong were resolved, a huge amount of new knowledge and actual samples, which could be accurately and appropriately classified, has gradually been accumulated. Because of the number of described species and subspecies, with varying accuracy of description, this has led not only to considerable confusion but has also made the definition of other new taxa, with the corresponding nomenclatorial rules, impossible. As will be evident from the chapter on development of the classification of aptychi, the standard of systematic view achieved, classification and nomenclature does not now satisfy present-day principles.

In this work, we therefore propose a new method for the classification of aptychi which occur in the Early Cretaceous and are characterised by ribbed calcite valves arranged in pairs, thus also designating them as diaptychi. However, both the valves rarely occur together.

Because some ribbed aptychi occurring during the Early Cretaceous had their origin in the Late Jurassic, we also had to take into account some Late Jurassic representatives, especially Tithonian. In addition, the concept of where exactly in time the Jurassic/Cretaceous boundary is has developed over many years. The $\mathrm{J} / \mathrm{K}$ boundary has 
represented a source of controversy during the last decades (see e.g. Michalík et al. 2009). The problem exists mainly due to the differences in local facies in the various regions of the world (Brodno in western Slovakia - Houša et al. 1996, 1999; Michalík et al. 2009; Bosso Valley in central Italy - Houša et al. 2004; Nordvik Peninsula in Russia Houša et al. 2007; Puerto Escaño in southern Spain Pruner et al. 2010), the lack of ammonites, and reliable index fossils. To date four variants of the $\mathrm{J} / \mathrm{K}$ boundary have been drawn: 1996);

1. the base of Durangites ammonite Zone (Houša et al.

2. the base of Berriasella jacobi ammonite Zone (Remane et al. 1986, Hoedemaeker et al. 1993);

3. the base of the Subthurmannia occitanica ammonite Zone (Ogg \& Lowrie 1986);

4. the base of Berriasella privasensis Zone (Tremolada et al. 2006). [Ammonite Standard Zonation for Berriasian, and also Valanginian-Hauterivian stages in the Taxonomic section according to Reboulet, Klein et al. 2009].

Today, the provisional $\mathrm{J} / \mathrm{K}$ boundary is usually favoured as the base of the Calpionella Standard Zone (e.g. Reháková \& Michalík 1997). It is about the base of Berriasella jacobi Zone; just as in this contribution.

The submitted proposal for a new classification of aptychi is connected with the taxonomic revision of the considerable number of species and subspecies so far described. The revision relies not only on literary data (Kratochvílová 2004), but mainly on our own rich source of material collected in the Western Carpathians and Eastern Alps over many years. Locations were preferred where the age (stratigraphic position) and succession of aptychi could be observed. This provided data for consideration of the basic phylogenesis of the aptychi.

Our stratigraphic data was usually based on the fact that the aptychi found by us often occurred together with ammonites. This joint occurrence can then sometimes provide data for identification of the stratigraphic position of
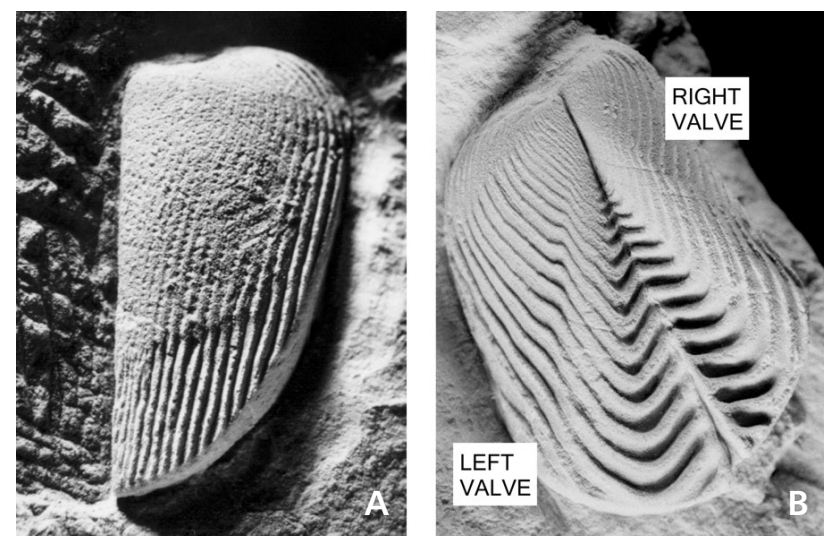

Figure 1. A - characteristic, almost universal subtrigonal shape of the valve of ribbed aptychus. $\bullet \mathrm{B}-$ left and right valves. the aptychi to the level of detailed ammonite stratigraphy, i.e. to the level of ammonite zones. On the other hand, it is necessary to state that we completely failed to find valves of aptychi directly in the shells of ammonites, which would have made it possible to classify aptychi as belonging to exact species of ammonites.

The Jurassic/Cretaceous boundary is usually not unambiguous with regard to ammonites, as they are often absent. For this reason, calcareous sediments in the Western Carpathians and Eastern Alps around the Jurassic/Cretaceous boundary, and also Early Cretaceous localities with aptychi, were also studied by means of thin sections, because microfossils, especially calpionellids, often occur in them. They usually provide suitable data for the delimitation of the Jurassic/Cretaceous boundary and make it possible to classify stratigraphically findings of aptychi at the level of the standard calpionellid zonation. However, it is necessary to point out that calpionellid stratigraphy is a reliable tool applicable only from the uppermost Jurassic to the Early/Late Valanginian boundary.

In the photo plates, the aptychi valves are orientated according to their predicted natural position.

Valves of aptychi marked with inventory numbers, which are illustrated in the taxonomic section, will be or already are deposited in the collections of institutions given below; they begin with symbols specific for the institutions: 1. Collections from the area of Salzburg for the Geological Survey of Austria (Geologische Bundesanstalt Wien): GBA 2009/007. 2. collection from the Outer Western Carpathians for the Moravian Museum in Brno: Ge. 3. Collection from the Central Western Carpathians for the Slovak National Museum in Bratislava: SNM-Z. 4. Collection from the Northern Calcareous Alps in the Geological Museum of VŠB - Technical University of Ostrava: V95, V97.

At the beginning RNDr. Václav Houša, CSc. (Geological Institute of the Czech Academy of Sciences, Prague) was also a member of our team. V. Houša suddenly died in 2006 shortly after writing the first chapters. After a break, the reduced team continued with this work.

\section{Basic characterisation and morphology of aptychi}

An overview of the opinions regarding the function of aptychi and their supposed position in the soft body of the animal, with reference to the ammonite shell and the manner of aptychi fossilisation was compiled by Engeser \& Keupp (2002) and Reboulet \& Rard (2008). Engeser \& Keupp (2002) studied in detail aptychi preserved in living chambers, i.e. in situ, in the case of 19 natural taxa of Jurassic and Cretaceous ammonites (usually at the level of family or superfamily). They confirmed the already known 
fact that calcareous lamellaptychi and punctaptychi occur in situ only in the family Haploceratidae.

Jurassic and Cretaceous aptychi are considerably diversified. Engeser \& Keupp (2002) included the neoammonites with calcified lower jaws of aptychi into a new, informal taxon Aptychophora.

Diaptychi form bilaterally symmetric pair systems. The system consists of the right and left valves, which are subtrigonal in shape (Fig. 1A, B), the axis plane - symphysis - runs between these valves (Fig. 1B).

\section{Historical overview of morphological terminology}

For a long time, considerable discrepancies has existed in the morphological terminology of aptychi. Trauth (1927-1938) was the first person who described and illustrated them terminologically in detail, and, as a result, he standardised descriptive nomenclature for aptychi. In chapter B (subchapter b) of his publication in 1927, Trauth linked other terms which had been used for the same element by his forerunners to each of his morphological terms. In this way he actually presented proof of the considerable confusions in terminology and method, which thanks to his work, led to the unification of morphological nomenclature. Trauth (1930) returned once more to terminology, in particular to the prefix 'Umbonal-', which he replaced by the prefix 'Umbilical-' (p. 337).

Arkell (1957) respected Trauth's terminology; but in principle, in his own illustrations he adopted it in only a very simplified form (see fig. 556), but did not write any explanation. The perspective representation of the left valve is incorrect in the area of the terminal edge, because he showed the outer edge and the outer margin as converging in the valve instead of being subparallel. One year later, Schindewolf (1958), in his comprehensive publication, also expanded on the morphological terminology of aptychi, which he - in contrast to Arkell - did not illustrate but merely commented upon. In places, he proposed terminological modifications. For instance, on page 7, unlike the prefixes 'Intern-' and 'Extern-' proposed by Trauth, he used the prefixes 'Dorsal-' and 'Ventral-' (Arkell 1957, respected Trauth's prefixes). Furthermore, Schindelwolf did not agreed with Trauth's term 'length' (Länge) of the aptychus valve, preferring the term 'height' (Höhe). According to him, this is justified because when aptychi are situated in the presupposed position in the framework of the mouth of an ammonite shell, the longest line in relation to the observer (i.e. the distance between the terminal edge and the umbilical projection) appears as the height of the body chamber or ammonite mouth and not as the length. In principle, Gąsiorowski (1962b) created nothing new; he merely preferred his own denomination of 'terminal point' over the 'ventral' (terminal) angle proposed by Arkell (Trauth 1927, used the German term 'Terminalecke').

At present, Trauth's unifying conception of morphological nomenclature, enriched by suggestions by Gąsiorowski (1962b), which is more or less in accordance with Schindewolf (1958), is accepted in principle.

\section{Terminology used}

A diaptychus consists of two valves - the right and the left (Trauth 1927, Schindelwolf 1958). As far as valve orientation is concerned, the arched (ribbed) side of the valve is orientated towards the observer and the apexes of both valves are situated upwards. The right valve has the symphysal margin on the left; in the left valve, it is the other way round. Renz (e.g. 1972, fig. 1) misunderstood this definition in his work and thus orientated the sides of the valves erroneously.

In each valve, the convex (upper) and the concave (lower) side can be distinguished. On the concave side of the valve there are merely fine concentric growth lines that are not significant from the systematic point of view. Between the convex and the concave side of the valve is a facet. This is an area of varying thickness. The convex side of each valve can be subdivided, according to Trauth (1927), into the symphysal, inner, lateral and outer regions (Fig. 2A).

The contact line along which the right valve was connected with the left one is designated by Trauth (1927) as the ligament ('Band'). He contemplated the fact that both the valves were connected by means of an elastic joint. He thus accepted the theory that had been generally adopted in the past (he refers to, e.g., Meyer 1831). The region of symphysal margin includes a smooth narrow area running along this margin, which corresponds to the true thickness of the valve. This is designated as the symphysal (harmonic) facet (in some lamellaptychi this edge is exceptionally crenulated). This facet is the least thick in the apical area and thickest usually at the terminal point. The symphysal (harmonic) facet is delimited by the symphysal margin towards the outer part of the valve and towards the inner part by the symphysal edge. Furthermore, the symphysal facet can be delimited in the longitudinal direction - in the juvenile part by the apical edge and towards the outer part by the terminal edge.

The place where the symphysal and inner margins of the valve come into contact is designated as the apex, and the similarly formed part on the opposite side of the valve, where the symphysal part is in contact with the outer part as the terminal point. Regions adjacent to both these parts have adequate designations, namely the apical and terminal areas. Furthermore, a third type of 'apex' can be 

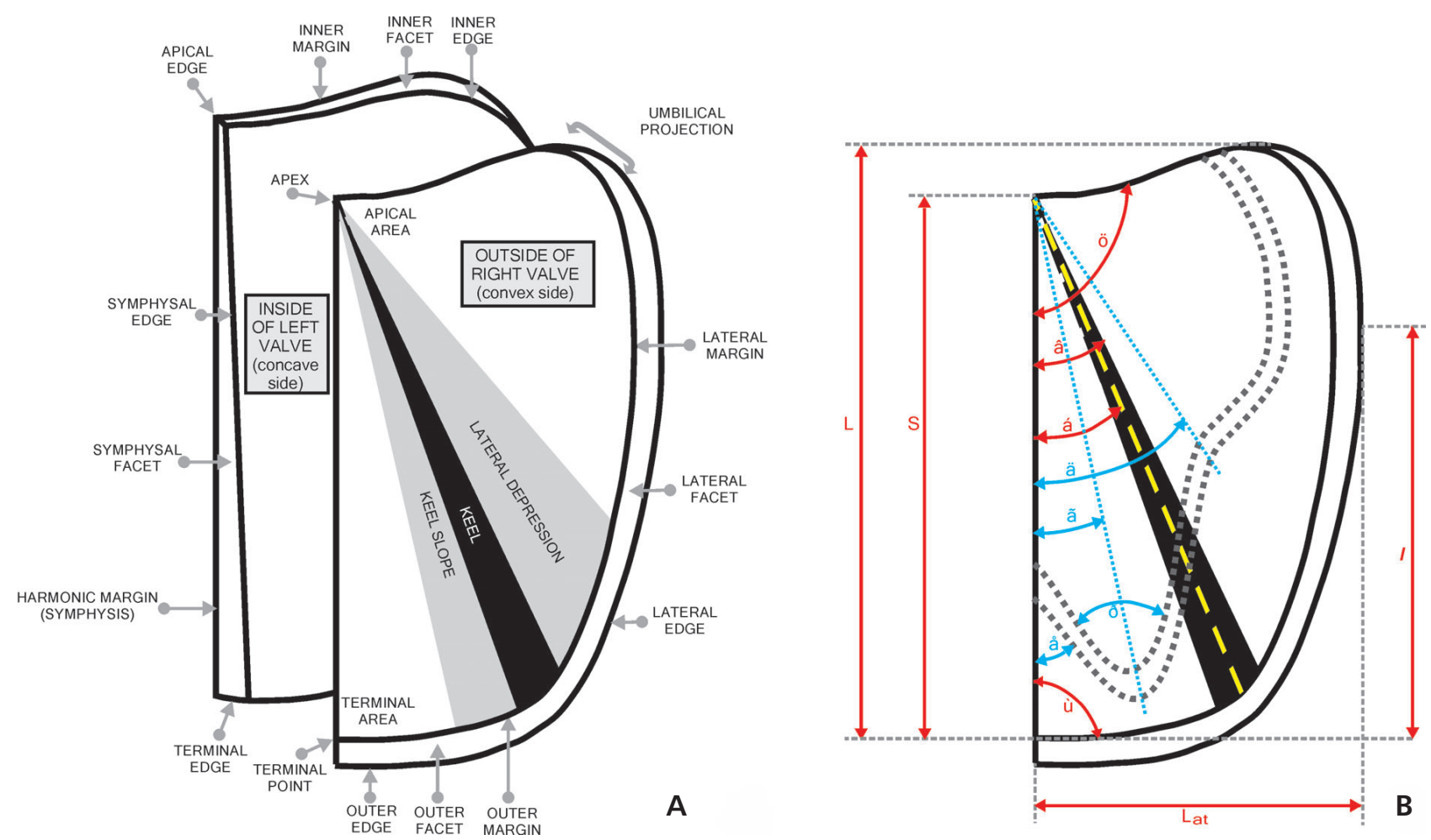

Figure 2. A - morphology of aptychi (modified from Trauth 1927, Arkell 1957, Gąsiorowski 1962b). • B - length and angular parameters measured on valves of ribbed aptychi, convex side of the right valve (modified from Gąsiorowski 1959).

observed on the valves and is designated as the umbilical projection. In the overwhelming majority of cases, there is no unambiguously defined point as in the case of the apex and terminal points.

Sometimes, across some vaulted valves, an elevation or keel runs obliquely from the apex to the outer margin. Just below it and parallel to the direction in which it runs, a relatively narrow concave zone, designated as the lateral depression, may be developed. Above the keel, a keel slope may also be developed.

If the valves are really complete and non-deformed (which is not always the case), their length and angular parameters can be utilised as a determinative criterion. Gąsiorowski's symbols (1962b), which are also used in this work, are presented here (Fig. 2B).

The index $L$ stands for the distance between the terminal point and the umbilicus projection, i.e. the total length of the valve (the height according to some authors). The maximum valve width is given by the index Lat. This is the distance between the symphysal margin and the maximum valve width. The length of the symphysal edge is designated by the index $S$ and expresses the distance between the apex and the terminal point. The distance between the terminal point and the point of maximum valve width (Lat) is designated by the index $l$. Whereas on a given line segment, the terminal point is clear, the position at the opposite end (the tangent to the little arched curve) cannot be de- termined with total accuracy. The ratios $S / L a t, L a t / L$ and $S / L$ produce numerical values by which the shape of the valve can be characterised. However, for incomplete valves, only the preserved parts were measured. We used the designations Lat' and L'. However, for the calculation of the above ratios, these parameters were totally useless.

It is also possible (but not usual) to use several angular measurements (see Fig. 2B). The value of $\alpha$ corresponds to the magnitude of the angle made by the symphysal axis and the keel axis. The angle between the axis of lateral depression and the symphysal edge is designated by the index $\beta$. The value of the seldom-used quantity $\varphi$ designates the magnitude of the apical angle and the index $\omega$ the magnitude of the terminal angle.

Moreover, the angles that characterise ribbing on the outer side of the aptychus can also be determined. For example, the angle $\varepsilon$, made by the ribs and the symphysal edge, and the angle $\pi$, made by two branches in the case of subangular to angular ribs. The angle $\gamma$, which is made by the axis about which a given type of rib bends and the symphysal edge of the valve, can also be defined. The axis of inflection of the ribs in the area of lateral depression with the symphysal edge produces the angle $\delta$.

From the ontogenetic point of view, the juvenile part (corresponding to the apical area and its nearest surroundings) and the adult part (corresponding to the remaining opposite part of the valve) can be recognised. 

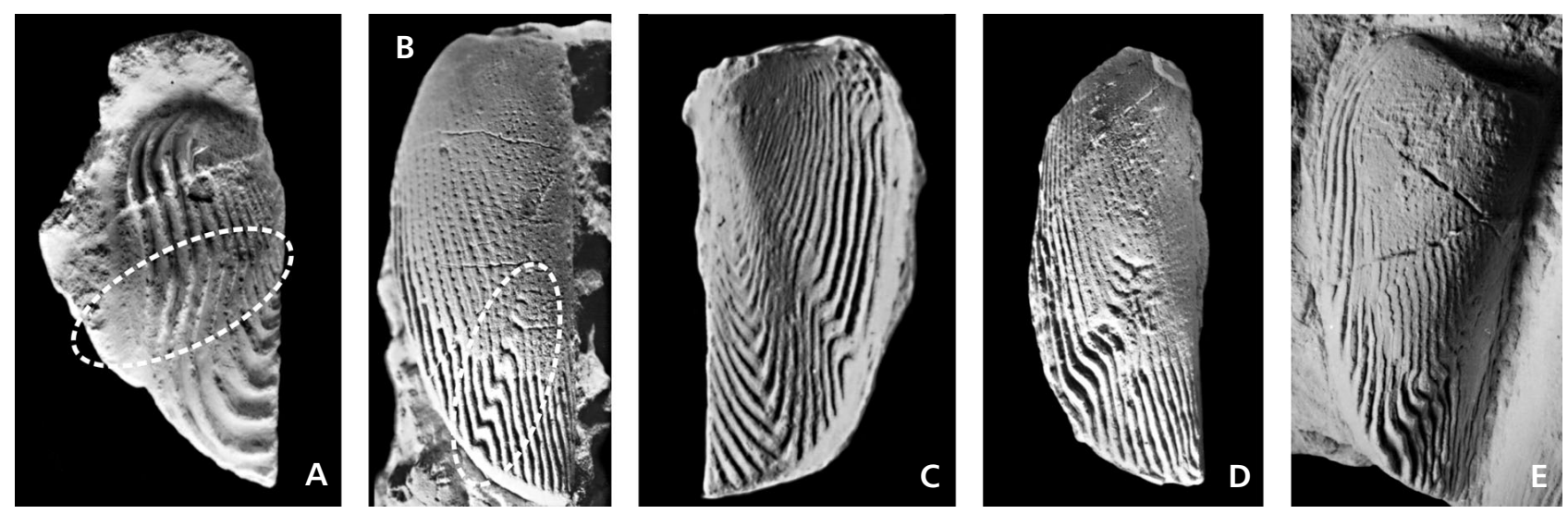

Figure 3. A-inflection. $\bullet \mathrm{B}-\operatorname{sigmoidal}$ bend. $\bullet \mathrm{C}-$ slight inflection passing into sigmoidal bend. $\bullet \mathrm{D}-\mathrm{S}$-shaped bending of ribs. $\bullet \mathrm{E}-$ multiple $\mathrm{S}$-shaped bend of ribs.

\section{Taxonomical significance of some morphological elements of ribbed diaptychi}

For the determination of ribbed calcite diaptychi, the convex (outer) side of valves, especially the arrangement of the lamella-like ribs, is important. In addition to the above mentioned main feature, some other morphological elements may occur on the valves. For example the inflection and sigmoidal bending of ribs, radial lines and possibly the length and also the width of the valves.

A shallower or more conspicuous bending of the ribs corresponds to the inflection of the ribs, which is usually confined to the area of lateral depression on the flank of the valve (see Fig. 3A). The sigmoidal or S-shaped bend can but need not be connected with the lateral depression (see Fig. 3B, and also Houša 1974, fig. 10). The sigmoidal bend may be curved or sharply angular (refracted). Both these possibilities were illustrated by Gassiorowski (1962b, figs $7,-f, f)$. Boundaries between the inflection, the sigmoidal curved bend and the sigmoidal refracted bend are not entirely clear. The development of the sigmoidal bend is usually highly individual. On some valves, more juvenile ribs do not show any bending at the beginning, but towards the more adult ones (towards the outer-lateral margin) a sigmoidal bend may appear (Fig. 3C). In other valves, development has the opposite tendency - from the sigmoidal bend to continuously running ribs (Fig. 1B). A third type can also occur, when only one kind of bend is preserved without substantial changes in more adult ribs (see Fig. 3D). Two types of S-shaped bending of the ribs are distinguisable, namely simple (e.g. Fig. 3B-D) and multiple (Fig. 3E).

Whereas the inflection of the ribs was considered to be of little importance to systematics, the sigmoidal bend was utilised by some authors taxonomically at the level of subspecies and named as fractocosta or fractocostatus. This nomenclature was introduced by Trauth $(1935,1938)$ in connection with the category n. var., which later acquired subspecies standing. The first time, Trauth used the designation var. fractocosta was in his systematic work on punctaptychi [1935: Punctaptychus punctatus (Voltz) var. n. fractocosta]. In the monograph on lamellaptychi, Trauth (1938) used the former name (e.g. Lamellaptychus beyrichi var. n. fractocosta) in some cases for the first time. In other instances he used fractocostata, and also in other similar combinations (e.g. Lamellaptychus angulocostatus var. n. symphysocostata). This element occured both in the punctaptychi and lamellaptychi during the entire time period we studied (Tithonian to Late Hauterivian).

The radial lines, as another controversial morphological element, are fine radial striae that run from the apex to the terminal area. Sporadically, a single line may occur (Fig. 4A), however more frequently a bundle of several lines occurs (Fig. 4B). Radial lines are found near the symphysal margin, more specifically in the area between the keel and the symphysal margin. They do not occur over the entire surface of the valve flanks as, e.g., was illustrated diagrammatically by Gąsiorowski (1962b, pl. 8). The lines are usually visible only when suitably illuminated (see e.g. Vašíček 1996, pl. 6, figs 5, 6), otherwise they disappear. Radial lines usually do not affect ribbing. A negligible offset or shift in ribbing at the point of intersection with the radial line may appear only sporadically. The presence of radial lines is usually utilised in the subspecies name radiata (radiatus). This name was introduced by Trauth [1938, p. 179: Lamellaptychus herthae (Wkl.) var. n. radiata - without illustration, and also p. 207, pl. 14, fig. 14: Lamellaptychus angulocostatus (Pet.) var. n. radiata].

The subspecies names longus and latus are similar in a way to the categories of sigmoidal bend and radial lines. These names, also used by Trauth [1935: Punctaptychus punctatus (Voltz) var. n. longa and P. punctatus (Voltz) var. n. lata] for the first time, are connected with the shape 

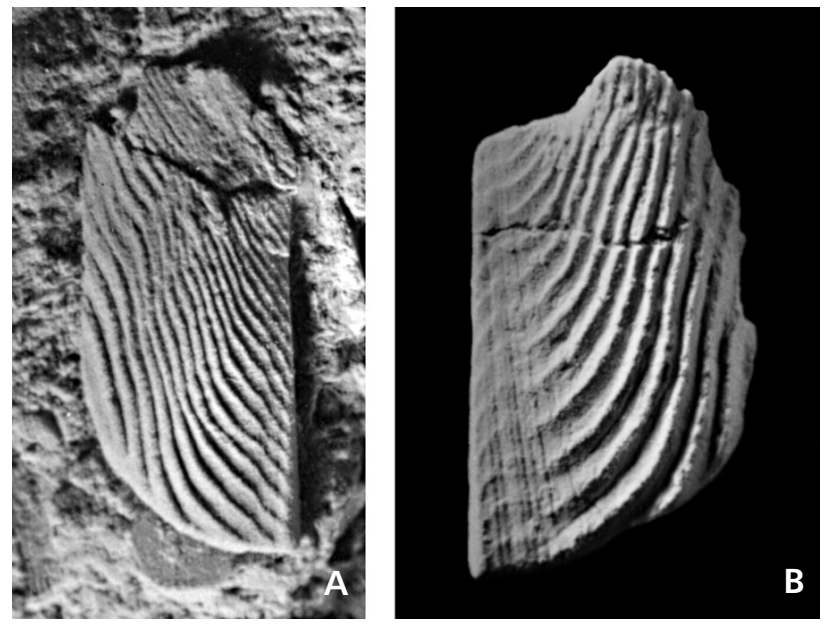

Figure 4. $\mathrm{A}$ - simple radial line. $\bullet \mathrm{B}$ - multiple radial lines.

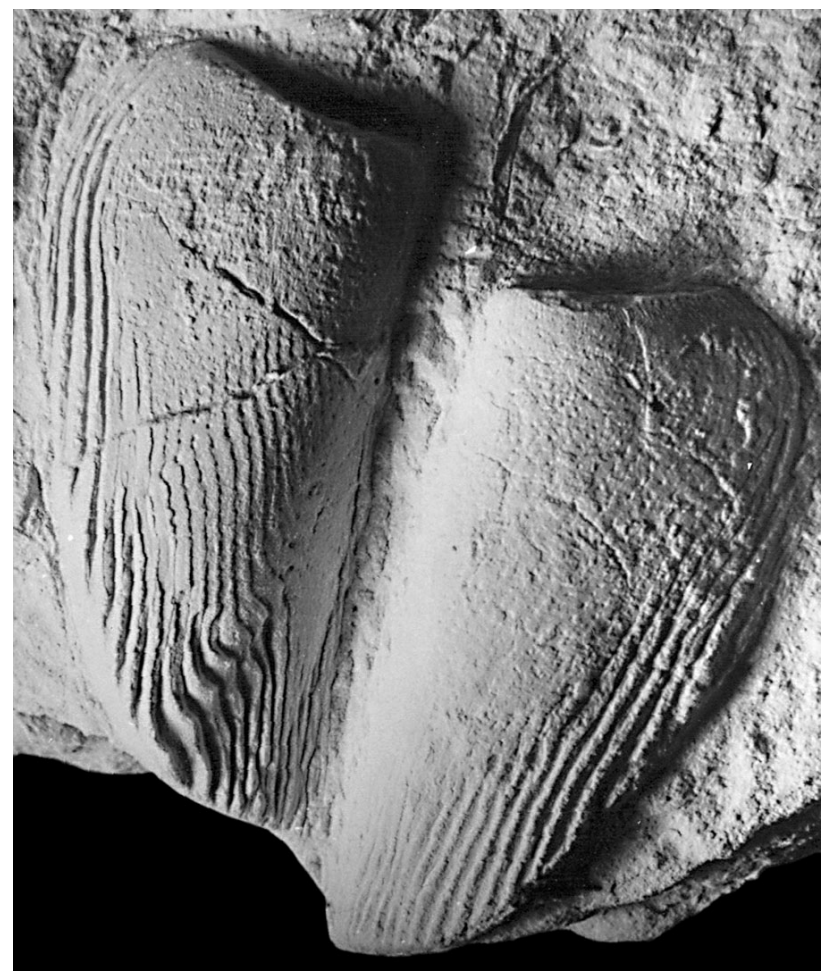

Figure 5. Pair of mating valves with different types of ribbing. Punctaptychus sp.; Kurovice locality, spec. Ge28815.

of the valves. They describe whether the valves are broad or slender. This characteristic can be expressed numerically by means of the ratio Lat/L. In many cases, the use of the subspecific names latus and longus is not logical because the shape of the valves can often be affected by deformation (especially in the case of heavily vaulted valves). Right and left valves preserved together under the name Lamellaptychus submortilleti, illustrated by Stefanov (1961, pl. 3, fig. 6), are classical evidence of such a manifestation. The right valve, which is 'rolled out' into the bedding plane, would correspond to the subspecies latus. The left valve, which is 'underlaid to ruffled under' by deformation, would correspond to the subspecies longus.

As already mentioned, the names fractocostatus, radiatus, latus and longus were utilised nomenclatorially by older authors in the naming of new subspecies. Nevertheless, we believe that the names fractocostatus and radiatus especially are of no taxonomic importance.

The element fractocostatus is an unstable morphological feature, characterised by the sigmoidal bend of the ribs. The fact that this is an unimportant feature is proved by aptychi in which both valves are preserved together and one of the valves has developed a sigmoidal bend, whereas the other has not (see Fig. 5).

Radial lines have no influence on ribbing. Their occurrence is probably associated with an exceptionally favourable manner of preservation. In some cases it seems that the radial lines represent the remnants of a thin layer of carbonised organic matter that covered the calcite valves on the surface (see e.g. Stefanov 1961, text-figs 1, 2). Furthermore, it can be stated that in one and the same locality in the same horizon, and on valves with the same ribbing (i.e. on valves of the same species), both valves with radial lines and without them may occur together.

Other indirect reasons for refusing to use the subspecies names fractocostatus and radiatus for taxonomy are common nomenclatorial reasons. A problem of insufficient capability of the 'classification level' arose. We can give a theoretical example from the abundant representatives of angularly ribbed aptychi - a subspecies designated to date as Lamellaptychus angulocostatus angulocostatus (see Fig. 6A) as an example. If a sigmoidal bend appears on a valve with such ribbing in the area of lateral depression (see Fig. 6B), then such a valve should be designated as $L$. angulocostatus fractocostatus. However, if such a valve has one, or rather more, radial lines instead of the sigmoidal bend (Fig. 6C), it should be designated as L. angulocostatus radiatus. The sigmoidal bend and the radial lines can, however, occur together on the same valve of ribbed aptychus (see Fig. 6D). At present, if we wanted to respect this fact nomenclatorically, we would have to come to a quadrinomial denomination - Lamellaptychus angulocostatus fractocostatus radiatus (or according to our present-day conception Didayilamellaptychus angulocostatus fractocostatus radiatus). But these and similar paradoxes have already occurred. Initially, this problem was solved by use of a hyphen (e.g. Trauth 1938: Lamellaptychus angulocostatus var. n. atlantica-radiata; similarly, Turculet \& Avram 1995, p. 97). Later, the hyphen disappeared (see e.g. Renz 1972), on p. 617 he used 

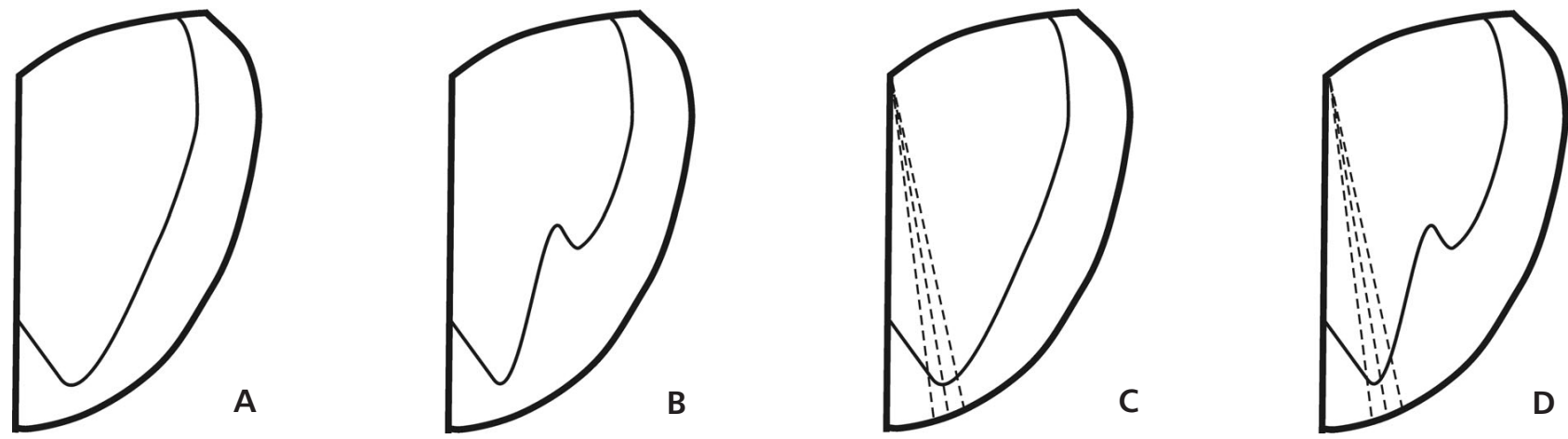

Figure 6. Possible variants of rib formation in Lamellaptychus angulocostatus Peters, 1854. A - L. angulocostatus angulocostatus Turculet \& Avram, 1995. • B - L. angulocostatus fractocostatus Trauth, 1938. • C - L. angulocostatus radiatus Avram, 1976. • D - L. angulocostatus fractocostatus radiatus - theoretical possibility.

Lamellaptychus angulocostatus atlanticusradiatus; however, in the explanation of pl. 3 , fig. 3 he introduced the form Lamellaptychus angulocostatus atlanticus radiatus.

Similar problems could appear in association with the subspecies names longus and latus. If the dimensions of perfectly preserved valves are not affected by deformation, corrosion or any other means, the stated names can, however, be objectively utilised.

\section{Proposal for a simplified designation of valve size}

The size of the adult calcite valves of ribbed aptychi has turned out to be a useful indicator. Trauth, in his work of 1927 (p. 210, fig. 5.1), used two basic terms to describe the size and the general shape of the valve. The first term was the length (Länge, assigned index L), which corresponds to the identical symbol L used at present (see Fig. 2B), and the other was the width (Breite, index B), for which the symbol Lat (Fig. 2B) is utilised in present day study of aptychi. On the basis of the ratio of parameters B : L, Trauth, in his work on laevaptychi (1931), designated the valves as very slender $(\mathrm{B}: \mathrm{L}<0.50)$, slender $(0.50 \leq \mathrm{B}: \mathrm{L} 0.67)$, stout $(0.67 \leq \mathrm{B}: \mathrm{L} \leq 0.80)$ and very stout (B : L > 0.80). Whereas Laevaptychus is designated from the point of view of the slenderness or stoutness of the valves and is considerably diverse, and the use of the criterion Lat/L in connection with designation appears to be useful, in punctaptychi and lamellaptychi the ratio Lat/L usually varies by only insignificant values. Therefore, it is more practical to divide the valves generally on the basis of size, i.e. length (L).

To acquire simple basic information about the size of the valves of punctaptychi and lamellaptychi, we propose that conventionally small $(\mathrm{L}<20 \mathrm{~mm})$, medium $(20 \mathrm{~mm} \leq \mathrm{L}<40 \mathrm{~mm})$ and large $(\mathrm{L}>40 \mathrm{~mm})$ valves be distinguished.

\section{Development of aptychi classification and a proposal for modifying the taxonomy of ribbed aptychi}

\section{Historical overview}

The first consideration of aptychi, defining their independent position, their systematic assignation and possible function was described in detail by Trauth (1927). The oldest studies from the $19^{\text {th }}$ century focused on the Early Cretaceous diaptychi with calcite valves and can be briefly summarised in the following way.

In the $18^{\text {th }}$ and at the beginning of the $19^{\text {th }}$ century, the opinion prevailed that aptychi belonged to the bivalves. Because of this opinion, various generic names were assigned to these aptychi, from which the generic name Trigonellites Parkinson, 1811 (with the type species Trigonellites lamellosus Parkinson, 1811) was the most significant or most used. According to strict nomenclatorial rules, this name would probably have priority over the generic name Aptychus, or names with the suffix '-aptychus' which were determined later. However, as already stated by Trauth (1927), it would be purposeless to change the introduced generic names connected with the basic name aptychus.

Meyer (1831; often the year 1829 is stated erroneously) was concerned with the genus Aptychus. He did not agree with previous opinions regarding the taxonomic classification of valves resembling the valves of bivalves into the bivalves plus some other groups. On the basis of his findings from the Late Jurassic, he thoroughly discussed their possible systematic classification. Among other matters, he also stated the opinion that valves could pertain to the inner shell parts of dibranchians, similar to the genera Sepia and Loligo ('acetabulifere Cephalopoden'). However, from the explanation to his plates 58 and 59 it follows that his valve findings were confined to the mouth area of ammonite type shells. His findings represent valves arranged in pairs that belong to two completely different morphological types. 
Meyer designated them as Aptychus laevis and Aptychus imbricatus. The first type is represented by smooth valves with a cellular structure; they correspond to the genus defined later as Laevaptychus. The other with simply ribbed valves correspond to the genus Lamellaptychus. Within the framework of Aptychus imbricatus he differentiated two forms: the well-preserved valves of Aptychus imbricatus profundus and the rather poorly-preserved, somewhat different valves of Aptychus imbricatus depressus with sparser ribbing. In the following years, a valuable finding was that Aptychus imbricatus profundus is identical to Trigonellites lamellosus Parkinson, 1811. The names imbricatus, profundus and depressus were subseqeuntly inconsistently interpreted by some authors as independent species. Up to now this has led to much nomenclatorial confusion.

Voltz (1837), in his work on Aptychus, like Coquand (1841), was concerned the systematical classification of aptychi. With reference to other findings of aptychi in the body chambers of ammonites, Voltz (1837) expressed the idea that these could be ammonite lids. Coquand (1841) did not incline towards this view. On the basis of valve composition, Voltz (1837) divided 25 species of aptychi, which according to him, belonged to a single genus Aptychus, into the following three families: Cornei (horny valves), Imbricati (ribbed calcareous valves) and Cellulosi (calcareous valves with a cellular structure). He made efforts to assign these families to corresponding groups of ammonites. In the list of species pertaining to the family Imbricati, he included Aptychus punctatus as a new species without giving a more detailed description and without any illustration. It came, allegedly, from the locality of Häring in Tirolia, from a formation not otherwise specified.

In addition to general discussion of opinions concerning the classification of aptychi, Coquand (1841) described and illustrated new species of aptychi from French localities. Undoubtedly from the Early Cretaceous, Aptychus didayi and A. seranonis were new conspicuously ribbed species.

Glocker (1841) studied the Jurassic Aptychus imbricatus Meyer, valves he had found in the locality of Kurovice (Czech Republic). In his description, he divided the valves into small and large. He illustrated the valves on pl. 3. The illustrated large valves are of two different structural types. In the incomplete valve in pl. 3, fig. 1, a so-called punctate layer in the vicinity of the apex is clearly drawn, but in the valve in pl. 3, fig. 2 it is absent. Each valve has its own specific ribbing. The valve in fig. 1 evidently belongs to the genus Punctaptychus, and the valve in fig. 2 to the genus Lamellaptychus. But none of his valves are identical with Aptychus imbricatus Meyer.

Later, Peters (1854) studied the aptychi. He paid special attention to Early Cretaceous occurrences in the Alpine-Carpathian area. He described among other things several new Early Cretaceous species: Aptychus angulocostatus, A. rectecostatus, A. aplanatus. His rather perfect species descriptions, however, are not accompanied by any illustrations.

Ooster (1857) used the generic designation Trigonellites Parkinson, 1811 for aptychi classified by him into cephalopods of uncertain systematic position. Ooster described again some previously known lamellaptychi from the peculiar designation of Giebel, 1852, although it was a species already named and described by Giebel's forerunners. In addition, several other new species of lamellaptychi were described by Ooster.

Shortly after that, Pictet \& Loriol (1858) were concerned with Early Cretaceous aptychi. Besides the species mentioned above as determined by Coquand (1841), they described and illustrated two other new Early Cretaceous species: Aptychus angulicostatus and Aptychus mortilleti. All the aptychi are illustrated perfectly.

Further details of aptychi were provided by Gümbel (1861). Analogous to Peters (1854), in addition to several species known earlier, Gümbel described a few new species of aptychi. Nevertheless, he illustrated none of them. Only subsequent authors illustrated them under the authorship of Gümbel.

Oppel (1865) defined the Tithonian as a new, uppermost stratigraphical stage of the Jurassic system. He provided an extensive list of fossils, also new species, characteristic of the Tithonian stage, usually accompanied by a very brief description. Among them, Aptychus beyrichi (p. 547) is stated as a new species. Consequently, the fossils described by him were illustrated by Zittel (1868).

Pictet (1867) described and illustrated other Early Cretaceous aptychi. He also illustrated Coquand's species Aptychus didayi and A. seranonis. However, these specimens differ from the type material. He determined Aptychus malbosi as a new species, according to the punctate pores probably belonging to the category of punctaptychi.

In the monograph on Tithonian cephalopods from the Štramberk Limestone, Zittel (1868) illustrated two valves. He designated one as Aptychus punctatus Voltz and the other as Aptychus beyrichi Oppel. In reality it is the first illustration of a complete valve, because as already stated, the above-mentioned authors had not illustrated the relevant valves of newly denominated species.

At the same time, Winkler (1868) was concerned with Early Cretaceous fossils from the Bavarian Alps. Besides species descriptions, aptychi are also illustrated on manually drawn plates of poor quality. In them are some species described as new by Gümbel (1861) - e.g. A. undatus, and his new species, e.g. A. gümbeli, A. noricus and A. herthae. The majority of his illustrations are difficult to use owing to the standard of the drawings and the negligible sizes of the aptychi represented which are mainly juvenile valves or incomplete valves (pl. 4, figs 11-13, 17). 
The trend in Gilliéron's (1873) work was similar to that of Winkler. In figure plates of somewhat better quality than in the previous case, he illustrated some species determined by Peters (1854), some other species of Gümbel (1868), and further fragments of undeterminable punctaptychi under the names Aptychus malbosi Pictet and Aptychus beyrichi Oppel.

The historical development in the understanding of the genus Aptychus was terminated by Favre (1880) in the $19^{\text {th }}$ century. In his extensive paper on Tithonian fossils he also illustrated four species of already known ribbed aptychi.

As recently as in the $20^{\text {th }}$ century, O'Connell (1921) still classified ribbed aptychi from Cuba within the framework of the single genus Aptychus.

A fundamental change in the knowledge and classification of aptychi was linked with Trauth $(1927,1928,1930$, 1931,1936 ) in the first half of the $20^{\text {th }}$ century. For the classification of Mesozoic aptychi, he determined 14 genera (Trauth 1927). The genera were divided into species, which were often subdivided into special lower categories designated as varieties (var.). In addition to this, he also used the designation 'forma typica (f. typ.)' after the species name in cases of considered subspecies. In the determination of a new species, he used the abbreviations $n$. $n$. or n. f. inconsistently. Ribbed calcareous diaptychi from the genera Punctaptychus Trauth, 1927 and Lamellaptychus Trauth, 1927, which continued from the Jurassic to the Early Cretaceous, were processed by Trauth in separate monographs: Punctaptychus in the year 1935; Lamellaptychus in the year 1938. Trauth often approached species and the infraspecific classification of punctaptychi and lamellaptychi very liberally and inconsistently. Valves included under the name Punctaptychus punctatus (Voltz) f. typ. in Trauth (1935, pl. 12, figs 1-4) can be given as an example of the conspicuously different arrangements of ribbing on individual valves. In the latter mentioned monograph, with reference to a great variety of ribbing on the valves of representatives of Lamellaptychus, Trauth (1938) distinguished four basic groups of lamellaptychi according to the ribbing designated as types $a, b, c$ and $d$. If he did not consider a single original name to be sufficient for infraspecific classification, he added another name divided by a hyphen (e.g. Lamellaptychus angulocostatus /Pet./ var. n. atlantica-radiata). Another of Traunth's basic classification criterion is the division into categories of valves without any depression and valves with a lateral depression.

In the 1950s, there were extensive discussions on the way to deal with nomenclature of the isolated body parts of some groups of fossil animals which could not be normally classified or could not be classified at all into taxa determined according to the shells or the whole skeletons (e.g. jaw apparatuses of conodonts, fish scales and otoliths, skeletal elements of echinoderms, jaws of nautilids and also aptychi). The discussions culminated in a proposal by R.C. Moore and P.C. Sylvester-Bradley to designate these fossil elements as parataxa (Bulletin of Zoological Nomenclature, vol. 15, pp. 5-120, London, 1957). In this proposal, a parataxon was defined as a taxonomic category including isolated parts of bodies or development stages of animals. According to the decision of the permanent Committee on Zoological Nomenclature (based in London), parataxa were found to be unidentifiable with mother taxa determined according to complete (or adult) specimens. The group which could be classified by the Committee into parataxa would be, according to the International Code of Zoological Nomenclature (formerly Article 27a, presentday Article 23.3.2.1, more specifically 23.3.2.2), exempt from the operation of the rule of priority. This would be valid retroactively as well. However, inside this group, priority would be effective without limits. But such a group would otherwise be subject to all other provisions of the International Code, i.e. the principle of homonymy as well.

Simultaneously with the proposal by Moore and Sylvester-Bradley, and in the same issue of Bulletin of Zoological Nomenclature (1957), another solution for aptychi proposed by W.J. Arkell was submitted. He used the fact that names of aptychi commonly did not endanger the basic nomenclature of ammonites. They could endanger it merely in a case of identification of the shell of an ammonite with that of an aptychus. The name used for the aptychus then endangers the stability of the nomenclature used for the shell of the ammonite when the name used for the aptychus is the older synonym. Arkell wanted to avoid this by proposing the invalidation of all names used for the naming of aptychi ('deprive of availability in the zoological nomenclature').

In the Treatise of Invertebrate Paleontology (1957), part L (Ammonoidea), we thus find aptychi even processed twice, namely by Arkell (pp. L437-L441) and Moore \& Sylvester-Bradley (pp. L465-L471) independently of each other. Arkell, in his effort to invalidate generic names of aptychi nomenclatorially, stated neither type species for genera nor authors' names (with two exceptions). In his conception, generic names used are 'Trauth's form genera'.

Both the published proposals were submitted for a final decision to the Nomenclature Section of the $15^{\text {th }}$ International Zoological Congress in 1958; the Section rejected the proposals. The rejection of the proposed solutions meant that in each case of competing names used for the aptychus and the ammonite shell belonging to it should be dealt with independently. So, if the younger synonym was the name for the ammonite shell and if it was not appropriate to suppress it, according to this submitted proposal to the Committee, this younger synonym should be included into the list of protected names. This was done in several cases. Nevertheless, the name used for the aptychus has 
never replaced the younger synonym used for the ammonite shell.

In the second half of the $20^{\text {th }}$ century, Gąsiorowski (1959, 1960, 1962a, b) was mainly concerned with the study of aptychi. In his study on the Laevaptychus (1960) he divided the given genus into subgenera. However, he avoided any taxonomic revision of ribbed aptychi. As for ribbed aptychi with calcite valves, he introduced his own formal classification criteria. Gąsiorowski (1962b) divided the stated aptychi into four basic groups and designated them A, B, C or D. Those corresponded, in principle, to Trauth's (1938) groups $a, b, c$ and $d$. When necessary, he subdivided the groups, e.g. group D into subgroups $\mathrm{D} \alpha$ to D $\gamma$. However, for the nomenclature of lower taxa, he continued using specific Trauth's nomenclature of infrasubspecific names (varieties, forms). With reference to the fact that Trauth, among other matters, omitted the principle of nomenclatorial types, the status of taxa newly defined by Trauth as well as taken from older authors remained uncertain even after Gąsiorowski's classification.

Simultaneously Stefanov (1961) and Bachmayer (1963) published their findings on aptychi. Both adhered to the same principles of nomenclature as Trauth and Gąsiorowski. Besides species names, they continued using the variety (var.) category for lower subdivisions. According to the already published first edition of the Code of Nomenclature (Article 45e, ii) "The name published after the year 1960 as 'variety' or 'form' is regarded as the name of lower than subspecific level". This means that 'forms' lower than subspecies (infrasubspecific), determined after the year 1960, are excluded from the group of species and are taken as invalid.

"Neocomian" aptychi were discussed specifically by Jaksch (1968). He adopted the nomenclature for lamellaptychi from Trauth (1938). But for their names, he did not use italics because like some of his forerunners, he considered them to be morphological terms. He was not concerned with the detailed systematics of aptychi; he only concentrated on morphological and stratigraphic knowledge. Aptychi were not illustrated by photos but merely in drawings, usually characteristic form. Illustrations were usually accompanied by morphological explanations.

Subsequent authors concerned with aptychi at the end of last century pursued various partial objectives and did not revise the group either completely or partially. They used the categories of species and subspecies, using the binominal and trinominal nomenclatures (e.g. Renz 1972-1983, Khalilov 1978, etc.), some with italics, others without them, and they especially determined other new species and subspecies (e.g. also Renz \& Habicht 1985, and others). Renz designated new taxa inconsistently $e . g$. : 'n. sp.', 'new form' and 'new name'.

Khalilov's plates (1978), in which both already known and newly-determined species of aptychi are illustrated, are of very poor quality and sometimes unreadable. Khalilov later improved the illustrations in 1988.

At the end of the $20^{\text {th }}$ century, a new stage in the classification of aptychi was represented by Turculet (1994). For the general designation of taxa he explicitly used the term parataxa. He stated that the para-genus Lamellaptychus could be divided into four para-subgenera, morphologically corresponding to differentiation of ribbing, as in Trauth's (1938) types $a-d$ and also Gąsiorowski's (1962b) types A-D. These parasubgenera have long names derived according to the names of the type species (designated as 'parasubspecie tip'): Beyrichilamellaptychus, Lamellosuslamellaptychus, Thorolamellaptychus and Didayilamellaptychus. The last mentioned para-subgenus comprises aptychi with both backwardly bent and angularly arranged ribs. For reasons of homeomorphy, he mentions the use of the para-subgeneric name Beyrichipunctaptychus for some punctaptychi. In addition to the category of para-genus (Lamellaptychus) and para-subgenera, Turculet also used the category of para-species.

A year later, Turculet \& Avram (1995) applied, in addition to Turculet's subgeneric names for lamellaptychi (here under the general designation para-genus and para-subgenus), the para-subgeneric name Beyrichipunctaptychus Turculet, 1994 as well. In the full-named designation, in accordance with the classification modified by Turculet, they described some already known species and subspecies of aptychi and also two new parasubspecies (n. pssp.). In the lowest level of classification, they lacked further possibilities for nomenclature in the subspecies category. They solved this problem by following the example of Trauth (Lamellaptychus /Didayilamellaptychus/ angulocostatus atlanticus-radiatus Trauth, 1938) and used a hyphen.

None of the previous authors concerned with aptychi used the prefix 'para-' in connection with the classification category (e.g. para-genus). They understood the term para-taxa exclusively as a common designation.

Kozlova \& Arkadiev (2003) proposed a new generic name, Tauriaptychus, for ribbed lamellaptychi. As a type species, the name Aptychus angulicostatus (under the incorrect authorship of Peters) is used. According to the list of species that should pertain, in the opinion of these authors, to the newly determined genus, maybe all the species classified into the Lamellaptychus belong here. A reason for using the new generic name proposed by the abovementioned authors is the fact that Aptychus imbricatus Meyer, 1837 (correctly, the year 1831 should be given) is to represent the Punctaptychus. However, as already mentioned at the beginning of this chapter, Aptychus imbricatus Meyer is a younger synonym of Lamellaptychus lamellosus Parkinson, 1811, as already stated by Trauth (1938, p. 149). This species is also the type species for the Lamellaptychus (see e.g. Treatise - Arkell et al. 1957). For the sake of completeness, it should be stated that 
the type species suggested by the above mentioned authors, i.e. Lamellaptychus angulicostatus, and also L. angulocostatus (?), are in Turculet's (1994) list of most significant representatives of the para-subgenus Didayilamellaptychus Turculet, 1994.

Some subgeneric names proposed by Turculet (1994) were used by Kasumzade \& Rogov (2006) quite recently. However, they did not use the generic name Tauriaptychus.

It is probably suitable to point out here that the principles of classification and the nomenclature of taxa in specific fossil groups of isolated skeletal elements of animals are not actually different from similar taxonomic procedures used in the systematics of more completely preserved remains and should not cause any special difficulties. Systematic groups that we distinguish in the classification of these fossils are again standard taxa of common categories, such as species, genus and others, which must be designated by names according to valid rules, although we cannot classify them with certainty into any known taxa. The problem is that we know that they are isolated parts of the bodies of organisms, shells or skeletons which are already classified separately, and the taxa differentiated according to the shells and skeletons are designated by names. If we were able to reliably assign the studied isolated fossil remains to taxa differentiated on the basis of shells and skeletons, i.e. if we were able to identify the remains with them, the problem associated with their nomenclature would disappear. However, this is not possible at present and probably never will be.

In phytopaleontology independent names for taxa of isolated elements (leaves, fruits, wood, pollen and other parts) are usually tolerated for a long time. When it is discovered that a certain kind of pollen corresponds to a certain species, determined according to the leaves, their names do not compete with each other. In the names of some such taxa (sometimes also designated as morphotaxa), certain word designations showing the type of remains (e.g. 'pollenites' with pollens, 'xylon' with wood) are included, although this is not obligatory. Moreover, in the case of the generic names of aptychi, 'aptychus' is usually a part of a generic name. Nevertheless, in contrast to botanic nomenclature, the concept of 'morphotaxa' has not yet been adopted in zoological nomenclature.

\section{Justification for the proposal of a new classification of Early Cretaceous ribbed aptychi}

The huge diversity of ribbed diaptychi with calcite valves in the Early Cretaceous, manifests itself among other ways in the considerable number of species and subspecies described mainly in the past 50 years. This limited the possibi- lities for future classification of new, morphologically different findings, and in our opinion, insufficient attempts to solve these problems (as follows from the chapter on historical development in nomenclature) meant that we saw fit to submit a proposal for a new possible classification of the aforementioned aptychi.

One of basic problems seems to be the fact that ribbed diaptychi with strong, usually thick-walled calcite valves, have so far been classified under two generic names: Punctaptychus and Lamellaptychus. Only Turculet (1994) divided the Lamellaptychus into four subgenera, the names of which, however, merely replaced the historical division of lamellaptychi into four groups according to ribbing $(\mathrm{a}-\mathrm{d}$, and $\mathrm{A}-\mathrm{D})$. On the basis of our material and data in the literature, we have arrived at the conclusion that this subgeneric division fails to cover all the variability in ribbed aptychi, and that it would be suitable to determine some other new subgenera. This would cause an expansion of the Lamellaptychus into a disproportionate number of subgenera. Therefore we suggest using Turculet's subgenera and equivalents but to elevate them to the level of independent genera. As for genera, we propose to group them into new families: Punctaptychidae and Lamellaptychidae. We have not yet used the category of subgenus. This may become necessary in the future (e.g. for the division of the extensive genus Didayilamellaptychus).

Lower classification often uses the categories of species and subspecies. However, we utilise the lowest taxonomic category cautiously to enable its full potential to be utilised later.

We connected the use of specific species and subspecies names of ribbed aptychi with the revision of the large number of names used in the literature. But we focused largely on taxa contained in our Alpine-Carpathian material from the Early Cretaceous.

The starting point for our revision was the first description and the first illustration of the species. Our next actions were centred upon type material. In many cases, the revision was extremely difficult, as shown partly in the chapter on the history of aptychi research. The development of nomenclatorial rules also played a certain role in the work with older references. Publications in which the described species were also depicted were included especially into the synonymics of species. In some older contributions, some illustrations of aptychi are, however, so imperfect that we sometimes had to abandon the idea of using them.

What plays a decisive role in our generic as well as species level classification of ribbed aptychi is the arrangement of adult ribs. In well-developed aptychi, the ribbing of valves changes during the course of growth; sometimes substantially. In those instances, the juvenile part of the valves which preserves the original, initial features is thus also important, because juvenile ribbing is an indicator of phylogenetic relationships and is, therefore, of importance 

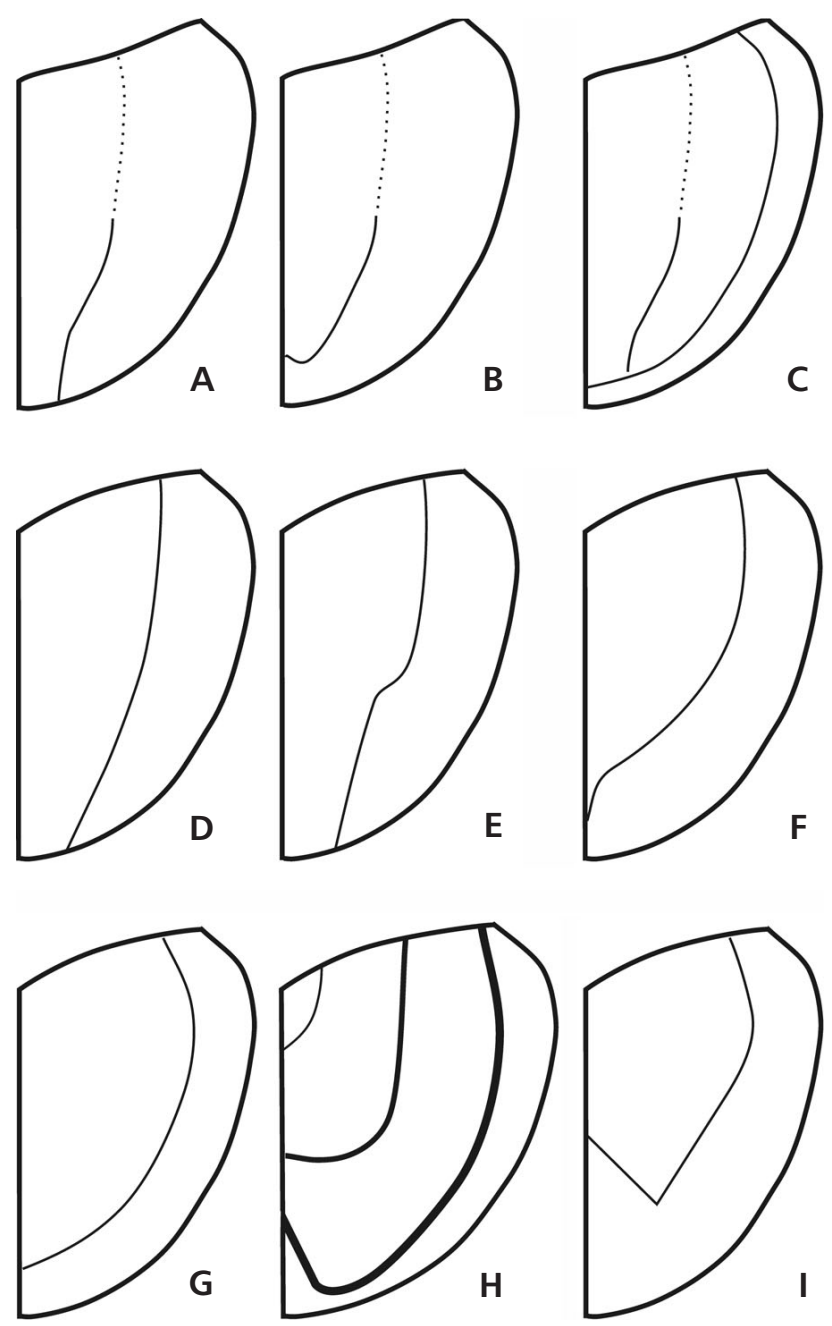

Figure 7. A - simple ribbing of Punctaptychus Trauth, 1927. • B - backward bend of adult ribs in some representatives of Punctaptychus Trauth, 1927. • C - discordant position of adult ribs in relation to juvenile ribs in Cinctpunctaptychus gen. nov. $・ D$ - diagrammatical sketch of ribbing in Lamellaptychus Trauth, 1927. • E - ribbing in Beyrichilamellaptychus Turculet, $1994 . \bullet \mathrm{F}$ - rib convergence in the vicinity of the symphysal edge in Mortilletilamellaptychus gen. nov. $\bullet \mathrm{G}$ - ribs following the outer margin of the valve in Thorolamellaptychus Turculet, $1994 \cdot \bullet \mathrm{H}$ - adult ribs in Didayilamellaptychus Turculet, 1994, bending backward in an arch-like manner. • I - angular ribs of Didayilamellaptychus Turculet, 1994.

to generic classification. Adult ribs also provide information on species and also subspecies assignation.

Perfect preservation of the valves or valves as complete as possible is of great importance for the correct determination of ribbed aptychi. Fragments of valves are not usually sufficient. Valves in which the terminal, i.e. adult regions, are missing are totally unsuitable. In addition to the morphological criteria, we have made efforts to utilise our phylogenetic knowledge in the proposal for a new classification.

Within the framework of Early Cretaceous ribbed diaptychi, we present the following basic scheme for a new systematic division (also see a short preliminary report in Měchová et al. 2008):

We divide the newly defined Punctaptychidae fam. $n$. (for details see taxonomic section) into the following two genera: Punctaptychus Trauth, 1927 and Cinctpunctaptychus gen. nov. A diagram of ribbing in the aforementioned genera is given in Fig. 7A-C.

The newly proposed Lamellaptychidae fam. n. is divided into the following five genera: Lamellaptychus Trauth, 1927, Beyrichilamellaptychus Turculet, 1994, Mortilletilamellaptychus gen. nov., Thorolamellaptychus Turculet, 1994 and Didayilamellaptychus Turculet, 1994. The basic arrangement of ribs is shown in Fig. 7D-I.

\section{Taxonomic section}

Family Punctaptychidae fam. nov.

Ribbed calcite diaptychi, the valves of which consist of four calcareous layers. The outer lamellar layer is overlaid by the uppermost porous (punctate) layer in a broad area near the apex. The margin between the apex and the inner edge is markedly concavely curved.

Type genus. - Punctaptychus Trauth, 1927.

Generic content. - Punctaptychus Trauth, 1927, Cinctpunctaptychus gen. nov.

Distribution. - Oxfordian to Berriasian, ?lowermost Valanginian.

\section{Genus Punctaptychus Trauth, 1927}

Type species. - Aptychus punctatus Zittel, 1868.

Description. - Thick-walled valves with simple ribbing (Fig. 7A). The length of the terminal ribs which run subparallel to the symphysal margin is considerable. A few ribs end at the symphysal margin, but most of them end at the outer margin of the terminal area. The terminal ribs may bend backwards towards the apex in the terminal region close to the symphysal margin (Fig. 7B) at the end of the existence of the genus, and only in adult valves.

Remarks. - The synonym of Punctaptychus is Beyrichipunctaptychus Turculet, 1994, which was determined on the basis of homeomorphy with Turculet's subgenus (Beyrichilamellaptychus) and is invalid. The author did not state any type species. According to the ribbing, this should be Aptychus punctatus. 
Species composition. - Punctaptychus punctatus (Zittel, 1868), P. rectecostatus Cuzzi, 1962, P. malbosi (Pictet, 1867), P. divergens Trauth, 1935, ?P. rousseaui Trauth, 1935, P. angustus Khalilov, 1978, P. seranonoides Turculet, 1995.

Occurrence. - Oxfordian to Berriasian, ?lowermost Valanginian.

\section{Punctaptychus punctatus (Zittel, 1868) Figure 8A}

1837 Aptychus punctatus nob.; Voltz, p. 435.

?1841 Aptychus imbricatus Meyer. - Glocker, p. 22, pl. 3, fig. 9 , non fig. 1 (= P. divergens Trauth), non fig. 2 (= ?Lamellaptychus rectecostatus Peters).

?1867 Aptychus imbricatus H. v. Meyer. - Pictet, pl. 43, fig. 8 a.

1867-81 Aptychus profundus (Voltz) Stop. (ex parte). - Stoppani in Meneghini, p. 122, pl. 25, figs 5a, b, non fig. 3 (= ?Lamellaptychus lamellosus Parkinson), non figs $4 \mathrm{a}, \mathrm{b}, ? 8 \mathrm{~d}$ (= P. divergens Trauth).

1868 Aptychus punctatus Voltz. - Zittel, p. 52, pl. 1, figs $15 \mathrm{a}, \mathrm{b}$.

1880 Aptychus punctatus Voltz. - Favre, p. 42, pl. 3, figs $14,15$.

1935 Punctaptychus punctatus (Voltz) f. typ. - Trauth, p. 315 , pl. 12, fig. 3, non figs 1,2 (= P. malbosi Pictet), non fig. 4 (=P. divergens Trauth).

1939 Punctaptychus zeijlmansi n. sp. - Koenigswald, p. 165, pl. 1, figs 7-10, non fig. 11 (= P. rectecostatus Cuzzi).

?1962 Punctaptychus punctatus (Voltz) f. typ. Trauth. Cuzzi, p. 48, pl. 17, figs 1-3.

1962a P. punctatus (Voltz) f. typ. Trauth. - Gąsiorowski, p. 260, pl. 17, figs 1,3 , non fig. $2(=P$. rectecostatus Cuzzi).

1962a P. punctatus (Voltz) var. fractocosta Trauth. - Gąsiorowski, p. 261 , pl. 17 , fig. 6 , non fig. 7 (= P. seranonoides Turculet).

1962b Punctaptychus, group A, punctatus (Voltz) f. typ. Trauth. - Gąsiorowski, pl. 6, figs 15, 16, non fig. 17 (=P. rectecostatus Cuzzi).

1962b Punctaptychus, group A, punctatus (Voltz) var. fractocosta Trauth. - Gąsiorowski, pl. 6, fig. 5, non fig. 6 (= P. seranonoides Turculet).

1963 Punctaptychus punctatus (Voltz). - Bachmayer, p. 130, pl. 4, figs 7a, b.

1964 Punctaptychus, grupa A, punctatus (Voltz), f. typ. Trauth. - Turculet, p. 62, pl. 5, fig. 7.

1965 Punctaptychus punctatus (Voltz). - Pozzi, pl. 86, figs $9, ? 10, ? 11$.

1972 Punctaptychus punctatus (Voltz). - Renz, p. 612, pl. 1, figs 5a, b.
1973 Lamellaptychus cf. rectecostatus (Peters). - Renz, pl. 1, figs $1,2$.

?1974 Punctaptychus punctatus punctatus (Voltz). - Khalilov et al., p. 173, pl. 8, fig. 16.

1976 Punctaptychus punctatus (Voltz) forma typica Trauth. - Patrulius \& Avram, p. 188, pl. 10, fig. 2, non fig. 1 (= P. angustus Khalilov).

1978 Punctaptychus punctatus punctatus (Voltz). - Khalilov, p. 56, pl. 2, figs 20, ?19, ?21.

1985 Punctaptychus punctatus Voltz. - Renz \& Habicht, p. 396, pl. 1, figs 18, ?17, ?19.

1988 Punctaptychus punctatus punctatus (Voltz). - Khalilov, p. 373, pl. 20, figs 2, ?1, ?3, pl. 22, fig. ?13.

1988 Punctaptychus imbricatus (Meyer). - Khalilov, p. 375 , pl. 21 , fig. 3,4 .

1990 Punctaptychus punctatus punctatus (Voltz). - Michalík et al., p. 77, pl. 5, fig. 1.

1995 Punctaptychus (Beyrichipunctaptychus) punctatus punctatus (Voltz). - Turculet \& Avram, pl. 6, figs 3, $? 2$.

1995 Punctaptychus punctatus punctatus (Voltz). - Reháková et al., p. 56, pl. 2, figs 1-3.

1996 Punctaptychus punctatus punctatus (Voltz). - Eliáš et al., pl. 4, fig. 3.

1996 Punctaptychus punctatus punctatus (Voltz). - Vašíček, pl. 1, fig. 1.

1996 Punctaptychus punctatus fractocostatus Trauth. Vašíček, pl. 1, fig. 1.

1996 Punctaptychus punctatus (Voltz) f. typ. Trauth. Jaksch, pl. 1, fig. 24.

1997 Punctaptychus punctatus punctatus (Voltz). - Vašíček \& Hoedemaeker, p. 32, pl. 1, figs 1, ?2.

non 1999 Punctaptychus punctatus punctatus (Voltz). - Kozlova \& Arkadiev, fig. 1 (= P. rectecostatus Cuzzi).

1999 Punctaptychus punctatus rectecostatus Cuzzi. - Kozlova \& Arkadiev, fig. 2.

2000 Punctaptychus punctatus punctatus (Voltz). - Boorová et al., pl. 13, fig. 7.

2000 Punctaptychus punctatus fractocostatus Trauth. Boorová et al., pl. 13, fig. 6.

2000 Punctaptychus punctatus punctatus (Voltz). - Vašíček et al., pl. 1, fig. 1.

2003 Punctaptychus malbosi (Pictet). - Kozlova \& Arkadiev, p. 38, pl. 7, fig. 2.

2003 Punctaptychus punctatus rectecostatus Cuzzi. - Kozlova \& Arkadiev, p. 38, pl. 7, fig. 7.

Lectotype. - With regard to the fact that Voltz (1837) neither described in detail nor illustrated Aptychus punctatus, this species name is not valid. Zittel (1868) used the name A. punctatus (under the authorship of Voltz) for well-preserved valves, and also described and illustrated them for the first time. Again under the authorship of Voltz, Trauth (1935) introduced P. punctatus into the 
professional literature, where it came into usage. With regard to these facts, and in accordance with the nomenclatorial rules, we selected the better preserved valve of two specimen illustrated by Zittel (1868) as A. punctatus as the lectotype (under the authorship of Zittel). That valve is illustrated by Zittel in pl. 1, fig. 15a. It comes from the Tithonian locality of Rogożnik in Poland.

Material. - Ten valves with various degrees of preservation. The best-preserved valve is Ge28810.

Description. - Small- to large-sized valves. The length of the adult valves is up to $50 \mathrm{~mm}$. The outer margin is wide and rounded. Ribs are simple and slightly bent. Near the symphysal margin in the terminal region, ribs are usually thin and close to each other. On the flanks of the valves, a simple to double sigmoidal bend may be developed.

Measurements. - The best and completely preserved valve with the identification number Ge28810 has the following parameters: $\mathrm{L}=18.9 \mathrm{~mm}$ and $\mathrm{Lat}=10.1 \mathrm{~mm}$, Lat $/ \mathrm{L}=0.53$.

Remarks. - Within the framework of $P$. punctatus, Trauth (1935) distinguished the varieties lata, longa and fractocosta. As already stated in the chapter on the morphology of valves, his varieties of lata and longa were determined on the basis of dimensions of incomplete valves. The sigmoidal bend and also the angular bending of the ribs on the flanks, lead Trauth introduce the variety fractocosta, which has no taxonomic importance (as explained in the chapter on morphology). In addition to the incomplete valve of Pictet (1867, pl. 43, fig. 8a), which has evident angular bending on its flanks, Trauth classified Vetters's specimen (1905, pl. 21, fig. 4) as the variety fractocosta. In Vetters's illustration, both the valves are present. On one of them, the sigmoidal bend is evident on the flanks, in contrast to the other valve. In the terminal area, the ribs are discordant in direction, especially on the right valve, and thus the specimen does not belong to $P$. punctatus.
Trauth (1935) also classified Pictet's A. malbosi as $P$. punctatus. Pictet's incomplete valve (1867, pl. 28, fig. 11) differs from $P$. punctatus in that it has large pores on a considerable part of its surface (which, however, can be greatly emphasised by illustration) and furthermore by the fact that the outer margin of $P$. malbosi is narrower.

Occurrence. - Patrulius \& Avram (1976) stated the Late Jurassic and Berriasian of the Mediterranean area, Khalilov (1988) the Tithonian to the Berriasian of Crimea, Azerbaijan and Europe. Vašíček et al. (2000), on the basis of calpionellids, made the upper boundary of the last occurrence more accurate (in the Alpine-Carpathian area) and stated the Late Berriasian.

In the Outer Western Carpathians (localities Kurovice, Horné Srnie), Central Western Carpathians (Strážovce, Zrázy) and Northern Calcareous Alps (Tirolicum and Bajuvaricum areas), the stratigraphic range of the species is, on the basis of microfossils, proved to be from the Early Tithonian (Parastomiosphaera malmica Zone) to all the Late Berriasian (calpionellid Calpionellopsis Zone, Calpionellopsis oblonga Subzone).

\section{Punctaptychus rectecostatus Cuzzi, 1962}

Figure 8B

?1857 Trigonellites cuneiformis Giebel; Ooster, p. 17, pl. 5, fig. 1.

?1867 Aptychus imbricatus H. de Meyer. - Pictet, pl. 43, figs 5-7, 9, 10, non fig. 8 .

1939 Punctaptychus zeijlmansi n. sp. - Koenigswald, p. 165, pl. 1, fig. 11, non figs 7-10 [= P. punctatus (Voltz)].

1962 Punctaptychus rectecostatus n. sp. - Cuzzi, p. 46, pl. 17, figs 4, 5, ?6s.

1962a P. punctatus (Voltz) f. typ. Trauth. - Gąsiorowski, p. 260 , pl. 17 , fig. 2.

1962b Punctaptychus, group A, punctatus (Voltz) f. typ. Trauth. - Gąsiorowski, pl. 6, fig. 17.

Figure 8. A - Punctaptychus punctatus (Zittel, 1868); ×2; spec. Ge28810. Kurovice Quarry, lowermost level (faunistic horizon Z), Rača Nappe, Outer Western Carpathians. Kurovice Limestone, Early Berriasian (Calpionella Zone, Calpionella alpina Subzone).・B - Punctaptychus rectecostatus Cuzzi, 1962; × 2; spec. Ge28811. Kurovice Quarry, lowermost level (faunistic horizon W). Kurovice Limestone, Early Berriasian (Calpionella Zone, Calpionella alpina Subzone). $\bullet$ C - Punctaptychus divergens Trauth, 1935; $\times 1$; spec. Ge28812. Kurovice Quarry, main level (horizon Y). Lower part of Kurovice Limestone, Early Tithonian (Parastomiosphaera malmica Zone). • D - Punctaptychus angustus A. Khalilov, $1978 ; \times 2$, spec. Ge28813. Kurovice Quarry, lowermost level (horizon W). Kurovice Limestone, Early Berriasian (Calpionella Zone, Calpionella alpina Subzone). - E - Punctaptychus seranonoides Turculet, 1995; × 1; spec. Ge28814. Kurovice Quarry, debris on the lowermost level. Kurovice Limestone, ?Early Berriasian. • F - Punctaptychus seranonoides Turculet, 1995; × 1; spec. Ge28816. Kurovice Quarry, lowermost level. Kurovice Limestone, Early Berriasian (Calpionella Zone, Calpionella alpina Subzone). $\bullet \mathrm{G}-$ Punctaptychus seranonoides Turculet, 1995; $\times 1$; spec. Ge28817. Kurovice Quarry, debris on the lowermost level. Kurovice Limestone, ?Early Berriasian. $\bullet$ H - Cinctpunctaptychus cinctus Trauth, 1935; $\times 3$; spec. Ge28818. Kurovice Quarry, upper level (horizon A1). Tlumačov Formation, Early Berriasian (Calpionella Zone, Remaniella ferasini Subzone). $\bullet$ I - Cinctpunctaptychus cinctus Trauth, 1935; × 3; spec. Ge28819. Kurovice Quarry, upper level (horizon A1). Tlumačov Formation, Early Berriasian (Calpionella Zone, Remaniella ferasini Subzone). - J - Cinctpunctaptychus undulatus sp. nov.; × 2; spec. Ge28820. Kurovice Quarry, lowermost level (horizon W). Kurovice Limestone, Early Berriasian (Calpionella Zone, Calpionella alpina Subzone). Scale is $10 \mathrm{~mm}$. 
Lucie Měchová et al. • Early Cretaceous ribbed aptychi
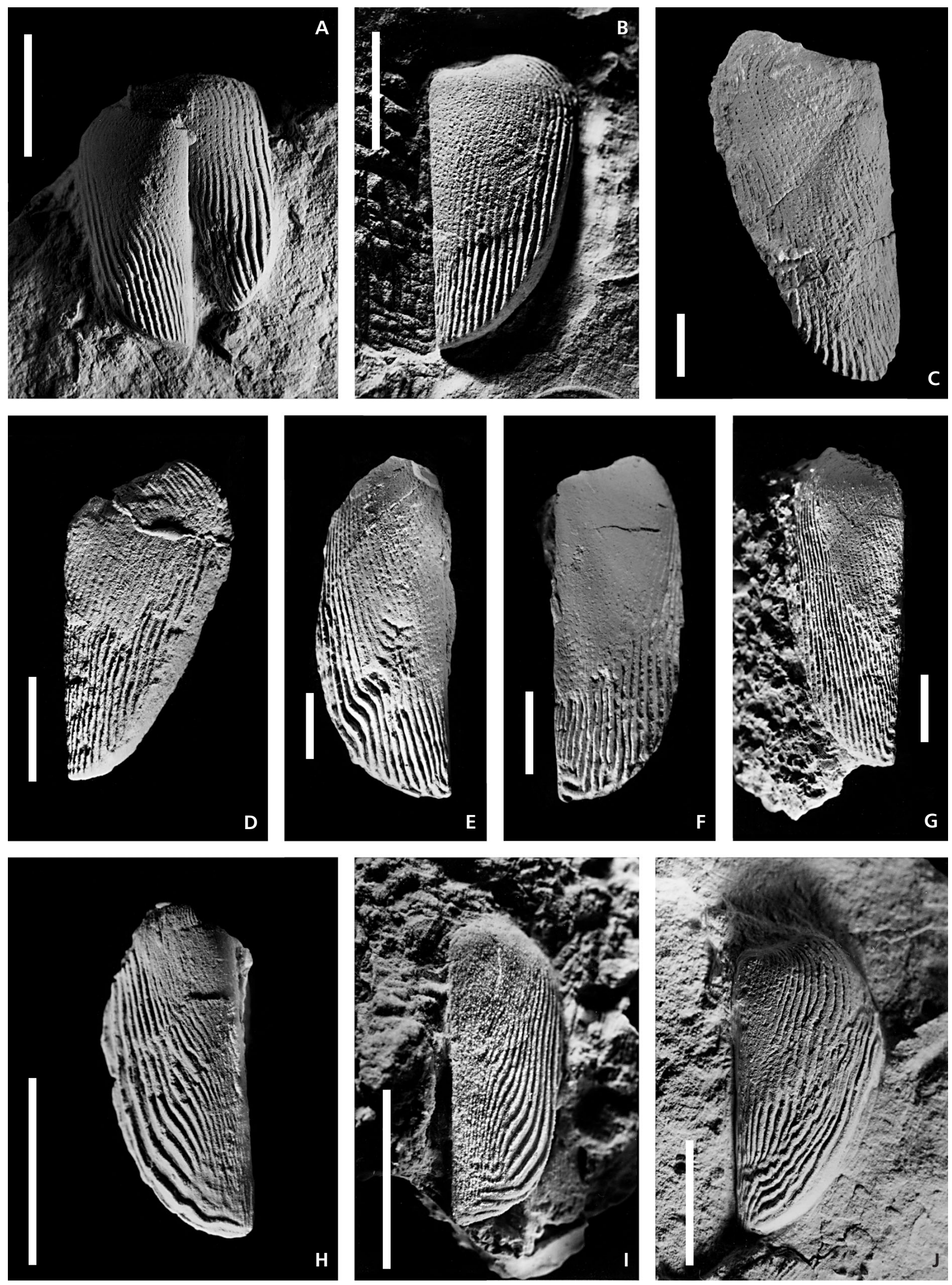
non 1970 Punctaptychus rectecostatus Cuzzi. - Lamagna \& Pingue, p. 234, pl. 5, figs 1, 9, 11, pl. 6, fig. 4 (= indeterminable).

?1990 Punctaptychus rectecostatus Cuzzi. - Michalík et al., p. 78 , pl. 5 , fig. 2 .

1994 Punctaptychus punctatus rectecostatus Cuzzi. - Vašíček et al., p. 69, pl. 23, fig. 1.

1995 Punctaptychus punctatus rectecostatus Cuzzi. - Reháková et al., p. 57, pl. 2, figs 4, ?5.

1996 Punctaptychus punctatus rectecostatus Cuzzi. - Vašíček, pl. 1, fig. 3.

1997 Punctaptychus punctatus rectecostatus Cuzzi. - Vašíček \& Hoedemaeker, p. 32, pl. 1, fig. 3.

non 1999 Punctaptychus punctatus rectecostatus Cuzzi. - Kozlova \& Arkadiev, fig. 2 [= P. punctatus (Voltz)].

1999 Punctaptychus punctatus punctatus (Voltz). - Kozlova \& Arkadiev, fig. 1.

1999 Punctaptychus malbosi Pictet. - Kozlova \& Arkadiev, fig. 3 .

Holotype. - Specimen defined by Cuzzi (1962, p. 46), illustrated in pl. 17 , fig. 5 .

Material. - Ten valves with various degrees of preservation. The best-preserved valve being specimen Ge28811.

Description. - Medium-sized valves (the length of the largest valve is more than $30 \mathrm{~mm}$ ). The valves are without a keel and a depression. Ribs are straight. A sigmoidal bend may occur on the flanks of some valves.

Measurements. - The completely preserved valve Ge28811 has the following dimensions: $\mathrm{L}=25.2 \mathrm{~mm}$ and $\mathrm{Lat}=14.0 \mathrm{~mm}, \mathrm{Lat} / \mathrm{L}=0.55$. Another complete valve designated Ge18814 has the dimensions: $\mathrm{L}=33.4 \mathrm{~mm}$, Lat $=$ $17.0 \mathrm{~mm}, \mathrm{Lat} / \mathrm{L}=0.51$.

Remarks. - Between $P$. punctatus with bent ribs and $P$. rectecostatus with straight ribs, forms exist which are transitional from the point of ribbing.

Occurrence. - Cuzzi (1962) and Renz (1973) assigned their $P$. rectecostatus to the Malmian (Italy and Central Pacific). Michalík et al. (1990) stated that in the Western Carpathians, exceptionally it occurs even in the lowermost Valanginian. In the studied section at Kurovice, within the framework of the Kurovice Limestone, the given species occurs, on the basis of calpionellids, from the Tithonian to the Early Berriasian (Vašíček et al. 1994, Eliáš et al. 1996). The same range is given by Vašíček \& Hoedemaeker (1997) from the Río Argos section in Spain.

In the Outer Western Carpathians (Kurovice), Central Western Carpathians (Strážovce, Nozdrovice) and Northern Calcareous Alps (Tirolicum and Bajuvaricum), the stratigraphic range of the species is from the latest Tithonian (calpionellid Crassicollaria Zone) to the Late Berriasian (calpionellid Calpionellopsis Zone, Calpionellopsis oblonga Subzone).

\section{Punctaptychus divergens Trauth, 1935}

Figure 8C

1841 Aptychus imbricatus v. Meyer; Glocker, p. 22, pl. 3, fig. 1.

1867-81 Aptychus profundus (Voltz) Stop. (ex parte). - Stoppani in Meneghini, p. 122, pl. 25, figs 4a, b, ?8d.

1935 Punctaptychus punctatus (Voltz) var. n. divergens. Trauth, p. 321, text-fig. 1 (= refiguration of Stoppani's holotype).

?1935 Punctaptychus punctatus (Voltz) f. typ. - Trauth, pl. 12, fig. 4 (= Glocker, 1841, pl. 3, fig. 1).

1957 Punctaptychus Trauth. - Arkell, Fig. 558, fig. 10a.

1960 Punctaptychus malbosi Pict. - Drushtchitz, p. 307, pl. 41, figs 5a, b.

1962a P. punctatus (Voltz) var. divergens Trauth. - Gąsiorowski, p. 261, pl. 17, fig. 8.

1962b Punctaptychus, group A, punctatus (Voltz) var. divergens Trauth. - Gąsiorowski, pl. 6, fig. 4.

?1964 Punctaptychus, grupa A, punctatus (Voltz), var. divergens Trauth. - Turculet, p. 63, pl. 5, fig. 8.

?1978 Punctaptychus punctatus divergens Trauth. - Khalilov, p. 57, pl. 2, figs 25, 26.

?1988 Punctaptychus punctatus divergens Trauth. - Khalilov, p. 374, pl. 20, figs 7, 8.

1996 Punctaptychus punctatus (Voltz) var. divergens Trauth. - Jaksch, p. 459, pl. 1, fig. 25.

1996 Punctaptychus punctatus divergens Trauth. - Eliáš et al., pl. 4, fig. 5.

1997 Punctaptychus punctatus divergens Trauth. - Vašíček \& Hoedemaeker, p. 32, pl. 1, fig. 4.

2000 Punctaptychus punctatus divergens Trauth. - Boorová et al., p. 307, pl. 14, fig. 2.

Holotype. - The holotype was determined by Trauth (1935, p. 321). It is the specimen designated by Stoppani in Meneghini (1867-81) as Aptychus profundus (Voltz), illustrated in pl. 25 , figs $4 a$, b.

Material. - Six well-preserved valves; the specimen Ge28812 is one of the best preserved.

Description. - Valves large in size. The ribs in the lower part of the valves and in the terminal area are radiate.

Measurements. - The completely preserved valve Ge28812 has the following dimensions: $\mathrm{L}=55.6 \mathrm{~mm}$ and Lat $=26.8 \mathrm{~mm}$, Lat $/ \mathrm{L}=0.48$. 
Remarks. - A fan-like arrangement of ribs is also illustrated in the case of Glocker's incomplete specimen (1841, pl. 3, fig. 1), but only along the outer margin, whereas along the symphysal margin the preserved ribbing corresponds to $P$. punctatus (Voltz).

Occurrence. - Trauth (1935) stated from the Tithonian to the Neocomian and Gąsiorowski (1962a) from the Kimmeridgian to the Tithonian. Boorová et al. (2000) found this species in the Eastern Alps in deposits near the Middle/Late Tithonian boundary. Vašíček \& Hoedemaeker (1997) stated the lowermost Berriasian (Río Argos, Spain).

In the Outer Western Carpathians (Kurovice) and Northern Calcareous Alps (Tirolicum) the stratigraphic range of the species is proved by calcareous dinoflagellates and calpionellids from the Early Tithonian Parastomiosphaera malmica Zone till the Early Berriasian calpionellid Calpionella Zone, Calpionella alpina Subzone.

\section{Punctaptychus angustus A. Khalilov, 1978}

Figure 8D

1976 Punctaptychus punctatus (Voltz) forma typica Trauth; Patrulius \& Avram, p. 188, pl. 10, fig. 1.

1978 Punctaptychus punctatus angusta A. Khalilov subsp. nov. - Khalilov, p. 57, pl. 2, figs 23, 24.

1979 Punctaptychus triangularis n. sp. - Kälin et al., p. 754, pl. 11, fig. e, pl. 12, fig. m.

?1987 Punctaptychus malbosi Pictet. - Nerodenko \& Riabucha, pl. 2, figs g, d.

1988 Punctaptychus punctatus angusta A. Khalilov. Khalilov in A. Ali-Zade et al., p. 374, pl. 20, figs 5, 6 (refigured from Khalilov 1978).

?1995 Punctaptychus (Beyrichipunctaptychus) punctatus punctatus (Voltz). - Turculet \& Avram, pl. 6, figs 2, 3.

2000 Punctaptychus punctatus angustus Khalilov. - Boorová et al., p. 308 , pl. 13 , fig. 3.

Lectotype. - The specimen of Khalilov (1978), designated as Punctaptychus punctatus angusta A. Khalilov, illustrated in his work in pl. 2, fig. 24, was selected as the lectotype. This lectotype is better illustrated in Khalilov (1988, pl. 20, fig. 6).

Material. - Three complete specimens with rather poor preservation. Valve Ge28813 is the best preserved.

Description. - Valves medium in size. A triangle shape, which is caused by a narrow side in the terminal area and an almost linear (i.e. not vaulted) outline from the point of the greatest width of the valve to almost the terminal apex, is typical. Ribbing is usually of a transitional type between
$P$. punctatus and $P$. rectecostatus. The length of the valves usually exceeds $30 \mathrm{~mm}$.

Measurements. - The completely preserved valve Ge28813 has the following parameters: $\mathrm{L}=32.1 \mathrm{~mm}$ and Lat $=16.9 \mathrm{~mm}$, Lat $/ \mathrm{L}=0.53$.

Remarks. - Kälin et al. (1979) and Khalilov (1978, 1988) depicted the same pairs of valves differing perhaps only slightly in outline. With reference to the fact that Khalilov illustrated $P$. angustus a year earlier than Kälin et al.'s $P$. triangularis, the latter became the synonym of the Khalilov species.

Occurrence. - Kälin et al. (1979) stated the Tithonian (Italy, SE of Tuscana), Boorová et al. (2000) the Late Tithonian of Northern Calcareous Alps (south of Salzburg), and Khalilov $(1978,1988)$ the Berriasian in the Caucasus.

The stratigraphic range of the species is from the Late Tithonian to the Early Berriasian calpionellid Calpionella Zone, but to the Calpionella alpina Subzone in the Outer Western Carpathians (Kurovice) and Northern Calcareous Alps (Tirolicum).

\section{Punctaptychus seranonoides Turculet, 1995}

Figure 8E-G

?1938 Lamellaptychus beyrichi (Opp.) var. n. seranonoides; Trauth, p. 198, pl. 14, fig. 2.

1962a P. punctatus (Voltz) var. fractocosta Trauth. - Gąsiorowski, p. 261, pl. 17, fig. 7.

1962b Punctaptychus, group A, punctatus (Voltz) var. fractocosta Trauth. - Gąsiorowski, pl. 6, fig. 6, non fig. 5 (= indeterminable).

1995 Punctaptychus punctatus seranonoides n. pssp. Turculet. - Turculet \& Avram, p. 98, pl. 6, figs 1, 1a.

2000 Punctaptychus punctatus seranonoides Turculet. Boorová et al., p. 308, pl. 13, fig. 4, pl. 14, figs 1, 6.

2000 Punctaptychus punctatus seranonoides Turculet. Vašíček et al., pl. 1, fig. 2.

Holotype. - The holotype was determined by Turculet in Turculet \& Avram (1995, p. 98). It is illustrated in pl. 6, figs $1,1 \mathrm{a}$ in that work.

Material. - Seven valves with various quality of preservation. The best preserved valves are specimens Ge28816, Ge28814 and Ge28817.

Description. - Valves usually large in size. Ribs in the symphysal area run subparallely to the symphysal margin. The last ribs suddenly bend back to the apex in the immediate vicinity of the symphysal margin. The ribs on the flanks 
of the valves may be arched with a tendency to run radially towards the outer margin; however, they may also be straight. On one valve, an S-shaped bend is developed in several ribs in the area of the keel. The length of Turculet's holotype is $45 \mathrm{~mm}$.

Measurements. - The complete valve Ge28817 has the following dimensions: $\mathrm{L}=48.2 \mathrm{~mm}$ and $\mathrm{Lat}=22.0 \mathrm{~mm}$, $\mathrm{Lat} / \mathrm{L}=0.46$.

Remarks. - A fragment of the terminal part of the large valve, illustrated by Trauth (1938) under the name Lamellaptychus beyrichi (Opp.) var. n. seranonoides, with no apparent punctate layer, could also belong to the described subspecies. With regard to the fact that the fragment does not include the apical area, to which the punctate layer is confined, the systematic classification of the valve concerned cannot be unambiguously decided.

The typical feature of the species, i.e. the backwards bend of the ribs in the terminal area of adult valves, differentiates $P$. seranonoides from the prevailing majority of representatives of the genus Punctaptychus. However, the backwards bending angular bend of the last ribs appears only in large-sized adult valves; it has not been found in juvenile valves. Equally large valves of the other species of the genus Punctaptychus do not possess this feature.

Occurrence. - Turculet \& Avram (1995) stated that the distribution of the type species is in the Tithonian of the area of Munteany and Svinita in Rumania. Boorová et al. (2000) found this species in the Late Tithonian in the Eastern Alps.

The stratigraphic range of the species from the Late Tithonian to the Early Berriasian (calpionellid Calpionella Zone, Calpionella alpina Subzone) was found in the Outer Western Carpathians (Kurovice), Central Western Carpathians (Strážovce) and Northern Calcareous Alps (Tirolicum and Bajuvaricum).

\section{Genus Cinctpunctaptychus gen. nov.}

Type species. - Punctaptychus cinctus Trauth, 1935.

Derivatio nominis. - According to the name of type species - cinctus.

Diagnosis. - Punctaptychi with considerably small valves on which juvenile ribs are discordant in relation to the last ribs (see Fig. 7C). Ribs are thin with regard to the small size of valves.

Description. - The juvenile part of the valves (if possible to judge according to the ribbing below the punctate layer) bears simple ribbing corresponding to that of Punctapty- chus punctatus. Adult ribs appear to more or less follow the outlines of the valves rather closely. Contact between the adult ribs and the juvenile ribs is disharmonic. Thin juvenile ribs form a bundle of thin ribs in the terminal area.

Species composition. - Cinctpunctaptychus cinctus (Trauth, 1935), ?C. pseudocinctus (Turculet, 1971), C. monsalvensis (Favre, 1880), C. undulatus sp. nov.

Occurrence. - Tithonian to Late Berriasian.

\section{Cinctpunctaptychus cinctus Trauth, 1935}

Figure $8 \mathrm{H}, \mathrm{I}$

1935 Punctaptychus cinctus n. f.; Trauth, p. 326, pl. 12, figs $11,12$.

1962a P. cinctus Trauth. - Gąsiorowski, p. 260, pl. 17, fig. 5.

1962b Punctaptychus, group A, cinctus Trauth. - Gąsiorowski, pl. 6, fig. 7.

1974 Punctaptychus cinctus Trauth. - Khalilov et al., p. 174 , pl. 8, fig. 18 .

?1976 Lamellaptychus gr. A sp. ind. - Patrulius \& Avram, p. 191, pl. 10, figs 10, 10a.

1994 Punctaptychus cinctus Trauth. - Vašíček et al., p. 70, pl. 23, fig. 2.

1996 Punctaptychus cinctus Trauth. - Vašíček, pl. 1, figs 5, 6.

1997 Punctaptychus cinctus Trauth. - Vašíček \& Hoedemaeker, p. 34, pl. 1, fig. 6.

2000 Punctaptychus cinctus Trauth. - Boorová et al., p. 310 , pl. 14, figs 4,5 .

2000 Punctaptychus cinctus Trauth. - Vašíček \& Faupl, p. 613 , pl. 1, fig. 2.

2003 Punctaptychus cinctus Trauth. - Kozlova \& Arkadiev, p. 39, pl. 7, fig. 5 .

2004 Punctaptychus cinctus Trauth. - Pszczólkowski \& Myczyński, p. 188, fig. 19.7.

Lectotype. - Valve depicted by Trauth (1935) in pl. 12, fig. 12. Tithonian, Arzberggraben near Waidhofen a. d. Y.

Material. - More than ten valves. Specimen Ge28819 is preserved best. The presence of a thin punctate layer was unambiguously verified using SEM (Scanning Electron Microscope) technology (spec. Ge28818).

Description. - Small and rarely medium-sized vaulted valves. The valves may have slightly indicated keels. Punctate layers are usually poorly developed, namely in a narrow area around the terminal apex. The juvenile and prevailing majority of adult ribs are simple. In the area of the keel, the ribs simply bend and run subparallel along the symphysal margin. The ribs along this margin are very closely spaced and thin in the terminal zone. The last, peripheral ribs are 
more solid and rather widely spaced. A proportion of them end discordantly below the bundle of thin, subparallel ribs. The latest ribs follow the outline of the valve. The last of them, usually near the terminal apex, may undulate slightly. The thin juvenile type ribs and the end ribs may overlap partly with each other.

Measurements. - The complete valve (Ge28818 - the valve was broken deliberately for laboratory investigation) has the following dimensions: $\mathrm{L}=17.4 \mathrm{~mm}$, Lat $=8.6 \mathrm{~mm}$, $\mathrm{Lat} / \mathrm{L}=0.49$. In specimen Ge28819 (also from Kurovice), the measurements were: $\mathrm{L}=18.2 \mathrm{~mm}$, Lat $=9 \mathrm{~mm}$, $\mathrm{Lat} / \mathrm{L}=0.49$.

Remarks. $-C$. cinctus is very similar to Beyrichilamellaptychus studeri (Ooster); it differs from B. studeri by the presence of a punctate layer. According to the formation of the apical area and the type of ribbing, Lamellaptychus gr. A sp. ind. (in Patrulius \& Avram 1976) stated in the synonymy, probably represents a juvenile valve of the species C. cinctus.

Occurrence. $-C$. cinctus is described from the Klippen Belt in Austria. It is known from the Eastern Alps, Spain, Pieniny Klippen Belt in Poland and from the locality of Kurovice in Moravia.

The stratigraphic range of the species is from the latest Tithonian to the Late Berriasian (calpionellid Calpionellopsis Zone, Calpionellopsis oblonga Subzone) in the Outer Western Carpathians (Kurovice) and Northern Calcareous Alps (Tirolicum and Bajuvaricum).

\section{Cinctpunctaptychus undulatus sp. nov.}

Figure 8J

?1938 Lamellaptychus lamellosus (Park.) var. n. cincta; Trauth, p. 190, pl. 13, fig. 20.

?1976 Lamellaptychus mortilleti (Pictet \& Loriol) forma n. zigzag; Patrulius \& Avram, p. 192, pl. 10, fig. 15.

Holotype. - Specimen Ge28820, illustrated in Fig. 8J will be deposited in the collection of the Department of Geology and Palaeontology of the Moravian Museum in Brno.

Derivatio nominis. - Undulatus - from Latin. According to undulated adult ribs.

Type locality. - Kurovice Quarry situated in the vicinity of the municipality of the same name.

Type horizon. - Kurovice Limestone, faunistic horizon W, Early Berriasian (calpionellid Calpionella Zone, Calpionella alpina Subzone).
Material. - Three valves. One is juvenile, the remaining two are adult but incomplete. The valve preserved best is specimen Ge28820.

Diagnosis. - Adult ribs are undulated, forming a disharmonic contact with juvenile ribs.

Description. - Medium-sized valves. Two types of lamellar ribs exist in the terminal area. The juvenile ribs converge along the symphysal margin. These ribs partly end at this margin and partly at the ribs of the other (undulatory) type. The following adult ribs are discordant in relation to the previous juvenile ones. Part of the discordant, undulated adult ribs follows the outline of the valve.

Measurements. - Holotype Ge28820 has the following dimensions: $\mathrm{L}=23.9 \mathrm{~mm}$, Lat $=12.4 \mathrm{~mm}$, Lat $/ \mathrm{L}=0.52$.

Remarks. - The valves of $C$. cinctus (Trauth) differ from the newly described species by the fact that merely a single last rib may be slightly undulated, whereas in $C$. undulatus sp. nov., several ribs are undulated. The development of the more mature ribs of $C$. undulatus sp. nov. resembles the subspecies described by Trauth (1938) as Lamellaptychus lamellosus cinctus. With reference to the missing apical part of Trauth's valve, where the punctate layer could have been developed, the possibility is not excluded that the valve concerned belongs to the family Punctaptychidae n. fam. and not to the family Lamellaptychidae n. fam.

Turculet (1971) defined a new species designated Punctaptychus, grupa A, pseudocinctus sp. nov. The holotype, represented by a large-sized valve, is illustrated in pl. 27, fig. 5. In the illustration the inflection of the adult ribs is evident, which could indicate a certain relationship with C. undulatus. However, the illustration is of such poor quality that neither the arrangement of the juvenile ribs nor the discordance between the juvenile and the adult ribs can be seen. In spite of the designation of the species to the name pseudocinctus, which indicates a relationship with C. cinctus, it is impossible to decide whether or not the given species belongs to Cinctpunctaptychus.

Occurrence. - At present, the species is known with certainty only from the locality of Kurovice (Outer Western Carpathians), from the carbonate deposits of the Early Berriasian (calpionellid Calpionella Zone, Calpionella alpina Subzone).

Family Lamellaptychidae fam. nov.

Diagnosis. - Calcite diaptychi, the valves of which are formed by three layers. Conspicuous ribs always present on the surface of the valves. The margin between the apex and the inner edge is straight to slightly vaulted. 
Type genus. - Lamellaptychus Trauth, 1927.

Generic content. - Lamellaptychus Trauth, 1927, Beyrichilamellaptychus Turculet, 1994, Mortilletilamellaptychus gen. nov., Thorolamellaptychus Turculet, 1994 and Didayilamellaptychus Turculet, 1994.

Occurrence. - Bajocian to Hauterivian.

\section{Genus Lamellaptychus Trauth, 1927}

Type species. - Trigonellites lamellosus Parkinson, 1811.

Description. - Weakly to rather markedly vaulted aptychi. Valves with simple, slightly arch-shaped ribs to almost straight ribbing. Some ribs end at the symphysal margin, and some at the outer margin (Fig. 7D).

Species composition. - Lamellaptychus lamellosus (Parkinson, 1811) and its numerous subspecies, L. undatus (Gümbel, 1861), L. sparsilamellosus (Gümbel, 1861), L. haufianus (Oppel, 1863), L. favrei Trauth, 1938, L. gillieroni Trauth, 1938, L. rectecostatus (Peters, 1854), L. herthae (Winkler, 1868) etc.

Occurrence. - Bajocian to Valanginian. The majority of species are known from the Jurassic; only the last two occur in, or are limited to the Early Cretaceous.

\section{Lamellaptychus herthae (Winkler, 1868)}

Figure 9A

1858 Aptychus Seranonis Coquand. - Pictet \& Loriol, pl. 11, fig. 3.

1868 Aptychus Herthae Winkler. - Winkler, p. 28, pl. 4, fig. 12.

1938 Lamellaptychus herthae (Wk1.) f. typ. - Trauth, p. 178, pl. 12, fig. 22.

1938 Lamellaptychus herthae (Wkl.) var. n. radiata. Trauth, p. 179.

1938 Lamellaptychus excavatus n. n. - Trauth, p. 178, pl. 12, figs 21, ?20.

1976 Lamellaptychus herthae (Winkler). - Patrulius \& Avram, p. 193, pl. 10, fig. 12.

1976 Lamellaptychus gr. A aff. L. rectecostatus (Pet.) em. Trauth. - Patrulius \& Avram, pl. 10, fig. 13.

1994 Lamellaptychus herthae (Winkler). - Vašíček et al., p. 71 , pl. 23, fig. 8 .

?1996 Lamellaptychus excavatus Trauth. - Vašíček, pl. 4, fig. 3.

2000 Lamellaptychus herthae (Winkler). - Vašíček \& Faupl, p. 613, pl. 1, fig. 3.
Holotype. - Winkler's specimen designated as Aptychus Herthae (Winkler, 1868, pl. 4, fig. 12).

Material. - Seven specimens of well-preserved valves. Specimen V95-3/4 is one of the most well-preserved valves.

Description. - Valves of medium size, with a keel and a lateral depression. Simple ribs end either at the symphysal margin, or at the outer margin, at an angle of 30 to $40^{\circ}$. In the depression on the flanks, ribs are negligibly to markedly inflected. Some specimens may have radial lines.

Measurements. - The complete and very well-preserved left valve of V95-3/4 has the following dimensions: $\mathrm{L}=$ $21.5 \mathrm{~mm}$, Lat $=10.1 \mathrm{~mm}$, Lat $/ \mathrm{L}=0.47$.

Remarks. - Winkler's holotype is a juvenile specimen, the illustration is, moreover, of poor quality. An adult valve was illustrated by Trauth (1938). We regard L. excavatus Trauth, 1938 as a synonym of $L$. herthae, the morphology of which is the same. The only difference could be the alleged straight ribbing in the lateral depression in Trauth's species; nevertheless we do not consider this to be a sufficient species marker.

Occurrence. - L. herthae (Winkler) is known from the lower part of the Late Valanginian of the Central Western Carpathians (Vašíček et al. 1994) and from the Late Berriasian of the Eastern Alps (Vašíček \& Faupl 2000). Patrulius \& Avram (1976) assigned their specimens to a wide stratigraphic range from the Tithonian to the Neocomian (Rumania).

In the Outer Western Carpathians (Kurovice), Central Western Carpathians (Strážovce, Nozdrovice, Pod Mráznicou) and the Northern Calcareous Alps (Bajuvaricum); the stratigraphic range of the species is from the Berriasian (calpionellid Calpionella Zone, Remaniella ferasini Subzone) to the Late Valanginian (last occurrence along the boundary between the ammonite Saynoceras verrucosum and Neocomites peregrinus Zones).

\section{Genus Beyrichilamellaptychus Turculet, 1994}

Type species. - Aptychus beyrichi Oppel, 1865.

Description. - Slightly to strongly vaulted valves. Majority of bent ribs converge along a rather long part of the symhysal margin, where they form a bundle of thin ribs close to each other (Fig. 7E). At the end of evolution of the genus, the original type of ribbing may end with several of the last ribs being discordant with the previous ones.

Species composition. - Beyrichilamellaptychus beyrichi (Oppel, 1865) with numerous subspecies in the Late Juras- 
sic, B. pseudostuderi sp. nov., B. transitorius Renz, 1978, B. studeri (Ooster, 1857).

Occurrence. - Kimmeridgian to Berriasian, ?Early Valanginian.

\section{Beyrichilamellaptychus beyrichi (Oppel, 1865)}

Description. - Small to medium-sized valves, slightly vaulted, without a keel or a lateral depression. Initially, ribbing is simple. Following a bend or subangular bend along the extended ribs, typical of the genus, straight ribs converge at the symphysal margin at a relatively acute angle. In the rear part of the valves along the symphysal margin, the ribs are straight, thinner, closely spaced, and arranged in a bundle. Juvenile ribs end at the symphysal margin; the majority of adult ribs end at the outer margin. On the flanks of the valves, other modifications in the arrangement of adult ribs in the form of sigmoidal bends, undulation, etc. may occur.

\section{Beyrichilamellaptychus beyrichi beyrichi (Oppel, 1865) Figure 9B}

?1857 Trigonellites curvatus Giebel. - Ooster, p. 20, pl. 5, fig. 11.

1865 Aptychus Beyrichi Opp.; Oppel, p. 547.

1868 Aptychus Beyrichi Opp. - Zittel, p. 54, pl. 1, figs 16-18, ?19.

1873 Aptychus Beyrichi (Oppel). - Gilliéron, p. 273, pl. 9, figs $9 \mathrm{a}, \mathrm{b}$.

1938 Lamellaptychus beyrichi (Oppel). - Trauth, p. 134, pl. 10, fig. 5 .

1938 Lamellaptychus beyrichi (Opp.) var. n. fractocosta. Trauth, p. 138, pl. 10, figs 10, ?11.

1958 Lamellaptychus beyrichi (Oppel) em. Trauth f. typ. Cuzzi, p. 256, pl. 12, figs 3, ?4, ?5, ?6.

1962a L. sp. 2. ex gr. a Trauth. - Gąsiorowski, p. 250, text-fig. 14 (figs 4, 9).

1963 Lamellaptychus beyrichi Oppel em. Trauth f. typ. Bachmayer, p. 126, pl. 1, fig. 4.

1964 Lamellaptychus, grupa A, beyrichi (Opp.), em. Trauth, f. typ. - Turculet, p. 59, pl. 3, figs 1-5, ?6.

?1972 Lamellaptychus beyrichi (Oppel). - Renz, p. 614, pl. 2 , fig. 3 .

1973 Lamellaptychus beyrichi (Oppel). - Renz, p. 640, pl. 1, fig. 19.

1976 Lamellaptychus beyrichi (Oppel) em. Trauth forma typica. - Patrulius \& Avram, p. 189, pl. 10, figs 4, ?5.

1978 Lamellaptychus beyrichi beyrichi (Oppel) em. Trauth. - Khalilov, p. 49, pl. 1, fig. 1.

1984 Lamellaptychus beyrichi beyrichi (Oppel). - Vašíček, p. 103, pl. 4, fig. 5 .
1984 Lamellaptychus beyrichi fractocostatus Trauth. - Vašíček, p. 104, pl. 4, fig. 6.

1985 Lamellaptychus beyrichi (Oppel). - Renz \& Habicht, p. 391, pl. 1, figs 5, 6 .

1988 Lamellaptychus beyrichi beyrichi (Oppel) em. Trauth. - Khalilov, p. 365, pl. 19, fig. 1, ?pl. 22, figs 35,36 .

1988 Lamellaptychus beyrichi longa Trauth. - Khalilov, p. 366 , pl. 19, fig. 4 .

1988 Lamellaptychus submortilleti longa Trauth. - Khalilov, p. 368, pl. 19, fig. 5.

?1990 Lamellaptychus beyrichi beyrichi (Oppel). - Michalík et al., p. 80, pl. 5, fig. 8 .

?1990 Lamellaptychus beyrichi fractocostatus Trauth. - Michalík et al., p. 82, pl. 5, fig. 5.

1990 Lamellaptychus submortilleti submortilleti Trauth. Michalík et al., p. 88, pl. 5, fig. 9.

1994 Lamellaptychus beyrichi beyrichi (Oppel). - Vašíček et al., p. 70, pl. 23, fig. 3 .

1995 Lamellaptychus beyrichi beyrichi (Oppel). - Reháková et al., p. 57, pl. 2, fig. 7.

1996 Lamellaptychus beyrichi (Oppel). - Vašíček, pl. 2, fig. 3 .

?2000 Lamellaptychus beyrichi (Oppel). - Boorová et al., pl. 14, fig. 8 .

Lectotype. - Zittel (1868) added illustrations of three valves to Oppel's (1865) description of A. Beyrichi. We propose the most well-preserved valve as the lectotype (Zittel 1868, pl. 1, fig. 17).

Material. - About 50 valves in various states of preservation. Specimen Ge00001 is the best preserved.

Description. - Valves small to medium in size, non-vaulted or only slightly vaulted. They have neither a keel nor a lateral depression. Ribs are relatively simple; they bend only slightly (in the area of the most conspicuous part of the convex vault). Some of the ribs converge longitudinally with the symphysal margin and some end at the outer margin. Ribs in the terminal area form a bundle of thin, closely spaced ribs. Inflected ribs may occur in the zone below the greatest convex vaulting of the valve. Refracted to sigmoidal bending of ribs may occur on the flanks of the valves.

Measurements. - The complete left valve of Ge00001 has the following dimensions: $\mathrm{L}=19.0 \mathrm{~mm}$, Lat $=10.1 \mathrm{~mm}$, Lat $/ \mathrm{L}=0.53$. The complete specimen 2025/9 (Strážovce locality) has the following dimensions: $\mathrm{L}=16.2 \mathrm{~mm}$, Lat $=$ $9.2 \mathrm{~mm}, \mathrm{Lat} / \mathrm{L}=0.57$.

Remarks. - B. beyrichi is subdivided into many subspecies. In addition to the type subspecies, the following subspecies are defined: B. b. moravicus (Blaschke, 1911), B. b. prae- 
seranonis (Blaschke, 1911), and B. b. platycostatus (Khalilov, 1978). The first differs from the type species by having denser and thinner ribs, the second has more solid, widely spaced ribs. B. $b$. platycostatus bears less abundant, largely flat ribs. B. b. longus (Trauth, 1938), B. b. undocostatus (Trauth, 1935) and B. b. subalpinus (Schafhäutl, 1853) are also defined. According to Trauth B. b. longus can be recognized on the basis of a somewhat lower ratio Lat/L, which we, however, consider to be an inconclusive criterion in this case. B. b. undocostatus (Trauth, 1935) is very similar to $B$. $b$. praeseranonis. The type specimen of the former has ribs with fainter sigmoidal bending (undulation) on the flank, as denoted by the subspecific name. With Trauth, the sigmoidal bend is usually connected with the use of the term fractocosta. As justified in our chapter on morphology, we do not consider this bend to be taxonomically usable, and thus we regard Trauth's "L. beyrichi (Opp.) var. fractocosta" as B. b. beyrichi. B. b. subalpinus (Schafhäutl, 1853) differs from B. b. beyrichi by having wide valves and somewhat different ribbing.

Lamellaptychus rectecostatus (Peters, 1854) has an interesting position in relation to the B. beyrichi. L. rectecostatus was regarded by Trauth $(1938$, p. 131) as an independent species, but is sometimes regarded as a subspecies of B. beyrichi (e.g. in Vašíček et al. 1994). Given that the mentioned specimens do not have any bundle of ribs in the terminal area, which is characteristic of $B$. beyrichi, it is more appropriate to consider Peters' species (legalized by Trauth as late as the year 1938) as a member of the Lamellaptychus (according to the conception proposed by us) and not as a representative of Beyrichilamellaptychus.
Occurrence. - B. b. beyrichi (Oppel) has a wide stratigraphic interval of distribution. Gąsiorowski (1962b) assigned it from the Kimmeridgian to the Early Berriasian. Boorová et al. (2000) assigned it to the Late Tithonian.

In the Outer Western Carpathians (Kurovice), Central Western Carpathians (Strážovce, Zrázy, Nozdrovice) and Northern Calcareous Alps (Tirolicum), the stratigraphic span of the subspecies is from the Early Tithonian (Parastomiosphaera malmica Zone) till the Berriasian, inclusively.

\section{Beyrichilamellaptychus pseudostuderi sp. nov. Figure 9C}

1962a L. studeri Oost. - Gąsiorowski, p. 251, fig. 14 (fig. 13).

1962b Lamellaptychus, group A, studeri (Oost.). - Gąsiorowski, pl. 7, fig. 14.

1962b Lamellaptychus, group A, "sp. 1 ex gr. a Trauth”. Gąsiorowski, pl. 7, fig. 13.

1968 Lamellaptychus studeri Oost. - Jaksch, p. 111, figs 26-29.

1976 Lamellaptychus beyrichi (Oppel) forma moravica (Blaschke). - Patrulius \& Avram, pl. 10, fig. 8.

1985 Lamellaptychus bahamensis Renz. - Renz \& Habicht, p. 403, pl. 5, fig. 23.

?1994 Lamellaptychus studeri (Oost.). - Vašíček et al., p. 71, pl. 23, fig. 12 .

1996 Lamellaptychus studeri (Ooster). - Vašíček, pl. 2, figs $8,9$.

1996 Lamellaptychus studeri (Oost.). - Jaksch, p. 457, pl. 1 , figs 8,9 .

Figure 9. A - Lamellaptychus herthae (Winkler, 1868); $\times 2$; spec. V95-3/4. Outcrop V95-3 on a forest path in the area of Steingraben, Schneeberg Syncline, Reichraming Nappe, Northern Calcareous Alps. Schrambach Formation, Late Berriasian (Calpionellopsis Zone, Calpionellopsis oblonga Subzone). • B - Beyrichilamellaptychus beyrichi beyrichi (Oppel, 1865); × 1; spec. Ge00001. Kurovice Quarry, debris of the lowermost level. Kurovice Limestone, Early Berriasian. • C - Beyrichilamellaptychus pseudostuderi sp. nov.; × 2; spec. Ge00002. Kurovice Quarry, upper level. Tlumačov Formation, Early Berriasian (Calpionella Zone, Remaniella ferasini Subzone). • D - Beyrichilamellaptychus studeri (Ooster, 1857 ); $\times 3$; spec. Ge00003. Kurovice Quarry, upper level. Tlumačov Formation, Early Berriasian (Calpionella Zone, Remaniella ferasini Subzone). • E - Beyrichilamellaptychus transitorius (Renz, 1978); × 2; spec. Ge00004. Kurovice Quarry, upper level. Tlumačov Formation, Early Berriasian (Calpionella Zone, Remaniella ferasini Subzone). $・ \mathrm{~F}-$ Mortilletilamellaptychus mortilleti (Pictet \& Loriol, 1858); $\times 3$; spec. V97-7c/11. Outcrop along a forest path in the area of Oisberg near Hollenstein a.d. Ybbs, Oisberg Syncline, Lunz Nappe, Northern Calcareous Alps. Schrambach Formation, base of Valanginian (ammonite Tirnovella petransiens Zone). • G - Mortilletilamellaptychus mortilletioides sp. nov.; × 3; spec. Ge00005. Kurovice Quarry, uppermost level (horizon D3). Tlumačov Formation, Early Valanginian (?Calpionellites Zone, ?Calpionellites darderi Subzone). $\bullet \mathrm{H}-$ Mortilletilamellaptychus mortilletinoricus (Trauth, 1938); × 2; spec. Ge00008. Kurovice Quarry, uppermost level (horizon E). Tlumačov Formation, Early Valanginian (Calpionellites Zone, Calpionellites darderi Subzone). • I - Mortilletilamellaptychus submortilleti submortilleti (Trauth, 1938); × 2; spec. Ge00006. Kurovice Quarry, lowermost level (horizon Z). Kurovice Limestone, Early Berriasian (Calpionella Zone, Calpionella alpina Subzone). • J - Mortilletilamellaptychus submortilleti noricus ssp. nov.; × 2; spec. Ge00007. Kurovice Quarry, lowermost level (horizon Z). Kurovice Limestone, Early Berriasian (Calpionella Zone, Calpionella alpina Subzone). $\bullet \mathrm{K}$ - Mortilletilamellaptychus helveticus (Renz \& Habicht, 1985); × 2; spec. Ge00009. Kurovice Quarry, uppermost level (horizon D2). Tlumačov Formation, Early Valanginian (Calpionellites Zone, ?Calpionellites darderi Subzone). • L - Mortilletilamellaptychus stanislavi sp. nov.; × 2; spec. Ge00010. Kurovice Quarry, uppermost level (horizon C). Tlumačov Formation, Early Valanginian (?Calpionellites Zone). - M - Mortilletilamellaptychus oceanicus (Renz, 1979); × 2; spec. SNM-Z24890. Revišné Locality, Slovakian Klippen Belt. Mráznica Formation, Late Valanginian (ammonite Neocomites peregrinus Zone, Olcostephanus nicklesi Subzone). $・ \mathrm{~N}-$ Mortilletilamellaptychus mendrisiensis mendrisiensis (Renz \& Habicht, 1985); × 2; spec. SNM-Z24891. Revišné Locality, Slovakian Klippen Belt. Mráznica Formation, Late Valanginian (Neocomites peregrinus Zone, Olcostephanus nicklesi Subzone). Scale is $10 \mathrm{~mm}$. 
Lucie Měchová et al. • Early Cretaceous ribbed aptychi
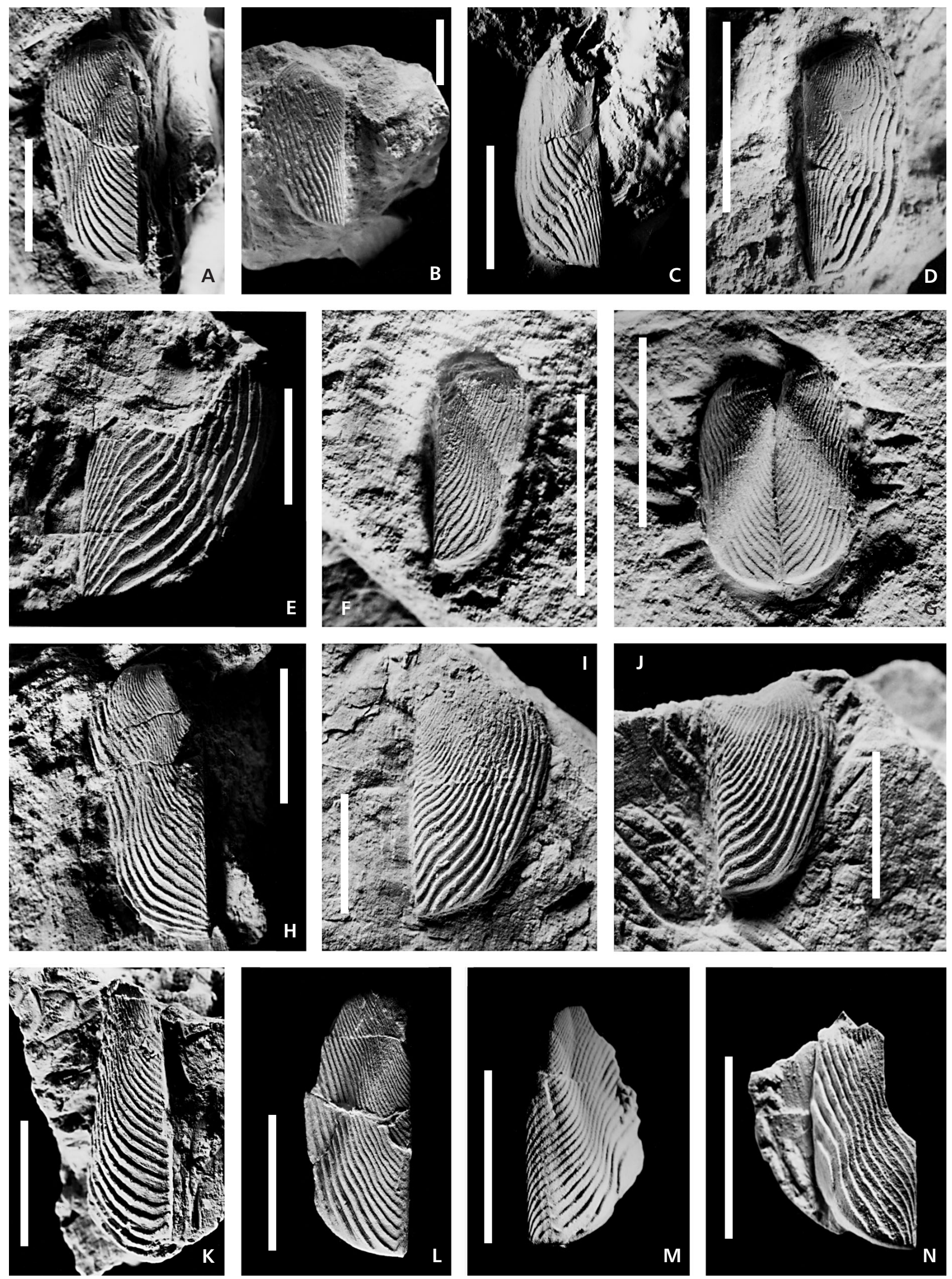
Holotype. - Valve, illustrated by Vašíček (1996) in pl. 2, fig. 8 under the name of Lamellaptychus studeri (Ooster). The valve will be deposited in the collections of the Department of Geology and Palaeontology of the Moravian $\mathrm{Mu}-$ seum in Brno under the number Ge00002.

Derivatio nominis. - In the course of more detailed revision it has become clear that forms commonly designated as B. studeri in the literature differ fundamentally from the lectotype determined by Trauth (1938). To draw attention to this confusion, we used a new species name pseudostuderi.

Type locality. - Kurovice Quarry situated in the vicinity of the municipality of the same name near Tlumačov in Moravia.

Type horizon. - Tlumačov Marlstone, younger Early Berriasian (calpionellid Calpionella Zone, Remaniella ferasini Subzone).

Material. - Twenty-one valves with various quality of preservation. One of the most well-preserved specimens is Vašíček’s (1996) specimen Ge00002.

Diagnosis. - Bent ribs near the symphysal margin converge simply along the symphysal margin. Valves are distinctly vaulted with a well-developed keel and a lateral depression.

Description. - Small, in exceptional cases medium-sized valves with a keel and a depression. The lateral depression is usually shallow. In addition to the lateral depression, a special type of depression between the keel and the symphysal margin also occurs. In the rear part of the valves, the ribs bend and converge along the symphysal facet. In the vicinity of the aforementioned margin, the ribs are closer together than subsequent peripheral ribs. The set of juvenile ribs forms a relatively large bundle of closely spaced ribs. The majority of the ribs end at the terminal edge.

Measurements. - The almost complete left valve of $\mathrm{Ku}-\mathrm{A} 1 / 5$ has the following dimensions: $\mathrm{L}^{\prime}=18.5 \mathrm{~mm}$, Lat' $=8.0 \mathrm{~mm}$.

Remarks. - When looking carefully at the original illustration of the Trigonellites studeri valve in pl. 7, fig. 4 in Ooster (1857), which was designated by Trauth (1938) as the type specimen of Lamellaptychus studeri Ooster at that time, it is evident that the valve is characterized by complicated ribbing connected with the discordance between juvenile and adult ribs. To date it has been interpreted erroneously as a valve with simple ribbing. We therefore propose a new species name for such valves. The species of B. pseudostuderi n. sp. is morphologically similar to B. beyrichi (Oppel). Nevertheless, the latter lacks any depression or a conspicuous keel.

Occurrence. - Under the name L. studeri, Gąsiorowski (1962a) and Jaksch (1968) assigned the species from the Tithonian to the Early Valanginian. Renz \& Habicht (1985) assigned the valve designated by them as L. bahamensis Renz, to the higher Early Valanginian. Vašíček et al. (1994) found their valves in deposits along the Tithonian/Berriasian boundary and the Early Valanginian. Vašíček (1996) placed his findings in the interval from the Late Berriasian to the lower part of the Early Valanginian.

In the Outer Western Carpathians (Kurovice, Horné Srnie), Central Western Carpathians (Butkov) and Northern Calcareous Alps (Tirolicum), the stratigraphic range of the species is from the Late Tithonian to the earliest Valanginian.

\section{Beyrichilamellaptychus studeri (Ooster, 1857)} Figure 9D

1857 Trigonellites Studeri Ooster; Ooster, p. 26, pl. 7, fig. 4, non figs 1-3, non fig. 6 (=M. breggiensis Renz \& Habicht), non fig. 7 (M. ex gr. mortilleti Pictet \& Loriol), non fig. 5 (= Thorolamellaptychus sp.).

?1938 Lamellaptychus lamellosus (Park.) var. n. cincta. Trauth, p. 190, pl. 13, figs 18-20.

1961 Lamellaptychus mortilleti (Pictet \& Loriol) var. radiata n. var. - Stefanov, pl. 3, fig. 3.

1962b Lamellaptychus, group A, lamellosus (Park.) var. cincta Trauth. - Gąsiorowski, pl. 6, fig. 21.

1964 Lamellaptychus, grupa A, cinctus n. sp. - Turculet, p. 61 , pl. 4 , fig. 3 , text-fig. 8 .

2000 Lamellaptychus cinctus Turculet. - Vašíček et al., p. 643 , pl. 1, fig. 3 .

Lectotype. - Of the set of valves designated by Ooster (1857) as Trigonellites Studeri, Trauth (1938, p. 144) designated the valve illustrated by Ooster (1857) in pl. 7, fig. 4 as the type specimen, i.e. the lectotype.

Material. - Thirty valves in varying degrees of preservation. One of the most well-preserved valves is specimen $\mathrm{Ge} 00003$.

Description. - Small to medium-sized valves without a conspicuous keel or a lateral depression. Juvenile ribs are closely spaced, at the beginning simple to slightly inflected. They converge almost subparallel along the symphysal margin, where they become thinner and denser. Peripheral, i.e. adult ribs, are arranged in a manner which resembles that of the ribs of L. lamellosus (Parkinson), and are discordant with the juvenile ribs. 
Measurements. - The almost complete right valve Ge00003 has the following dimensions: L' $=12.6 \mathrm{~mm}$, Lat' $=7.0 \mathrm{~mm}$.

Remarks. - Trauth (1938) selected the above-mentioned valve of Ooster (1857) as the lectotype of L. studeri, but he did not take into account the complicated ribbing of the mentioned type specimen. For this reason, for his $L$. studeri Trauth described only simple ribbing corresponding roughly to the ribbing of $L$. beyrichi (Oppel). On the basis of Trauth's description, erroneous interpretation of L. studeri appeared in the following years. Under magnification, Ooster's lectotype, which is small, clearly resembles the large valve that was described and illustrated by Trauth (1938) under the designation L. lamellosus (Park.) var. cincta (pl. 13, figs 18-20). The valve in question has a length of $72 \mathrm{~mm}$ (!). Adult ribs of Trauth's specimen, adjacent to the bundle of juvenile ribs, are somewhat different, because they undulate at the beginning. Nevertheless, the characteristic ribbing of $B$. studeri occurs in the latter case only much further on than in valves described as $B$. studeri. For this reason the identification of the lectotype of $B$. studeri with Trauth's above-mentioned large specimen is not unambiguous. The specimen of Stefanov (1961, pl. 3, fig. 3), in which radial lines are not true radial lines but lines pertaining to the end bundle of closely spaced, thin juvenile ribs, belongs to $B$. studeri as well. The ribs do not reach the apex as would be the case with true radial lines.

Occurrence. - Trauth (1938) assigned the species from the Tithonian to the Neocomian, Eliáš et al. (1996) to the Early Berriasian and Vašíček (1996) to the Late Berriasian.

In the Outer Western Carpathians (Kurovice), Central Western Carpathians (Nozdrovice) and Northern Calcareous Alps (Bajuvaricum), the stratigraphic range of the species is from the Late Tithonian (calpionellid Crassicollaria Zone, Crassicollaria colomi Subzone) to the Early Valanginian (calpionellid Calpionellites Zone, ?Calpionellites darderi Subzone).

\section{Beyrichilamellaptychus transitorius (Renz, 1978) Figure 9E}

1978 Lamellaptychus transitorius n. sp.; Renz, p. 903, pl. 1, figs 1a, b.

1996 Lamellaptychus elegans Renz.-Vašíček, pl. 3, fig. 1.

Holotype. - On the basis of monotypy, the holotype is the specimen figured by Renz (1978, pl. 1, fig. 1a) under the designation Lamellaptychus transitorius.

Material. - Ten fragmentary valves. Specimen Ge00004 is one of the best preserved.
Description. - Small to medium, slightly vaulted valves with an indicated keel. In spite of incompleteness, the valves appear to be wide. At the beginning, simple ribs follow the external outline of the valves. At some distance from the symphysal margin, they inflect from the original direction. Interrib spaces, before the mentioned inflection, are relatively wide. At the end of the symphysal region, the ribs are closely spaced over a relatively large area. They run obliquely and straight towards the symphysal margin and terminate at an angle of less than $30^{\circ}$ with the margin. Only the last few ribs (usually 4 to 6) do not end at the symphysal margin, but end at the terminal edge. Radial lines occur in some valves in the vicinity of the symphysal margin.

Measurements. - The right valve of fragment Ge00004 has the following dimensions: L' $=21.0 \mathrm{~mm}$, Lat' $=16.0 \mathrm{~mm}$.

Occurrence. - Renz (1978) reported the distribution to be in the surroundings of the Tithonian/Berriasian boundary from the area of the Blake-Bahama Basin.

In the locality of Kurovice (Outer Western Carpathians), Tlumačov Marlstone, it occurs in the Early Berriasian (calpionellid Calpionella Zone, Remaniella ferasini Subzone) and Late Berriasian (calpionellid Calpionellopsis Zone).

\section{Genus Mortilletilamellaptychus gen. nov.}

\section{Type species. - Aptychus Mortilleti Pictet \& Loriol, 1858.}

Derivatio nominis. - The generic name is deduced according to Gabriel de Mortillet, after whom the type species was also named by Pictet \& Loriol.

Diagnosis. - In the vicinity of the symphysal margin the majority of ribs bend towards the terminal point and end at the symphysal margin. Adult ribs end at the outer margin.

Description. - Small to medium-sized thin-walled aptychi with thin ribs. The valves, flat initially, become strongly vaulted with a lateral depression and a keel. Ribs slightly to strongly arch-shaped. Juvenile ribs and gradually also some of the adult ribs converge along the symphysal margin over a short or even rather long section and end at this margin. The last few ribs, with a few exceptions, end at the outer margin (Fig. 7F). At the end of evolution of the genus, the last few ribs may bend in a complicated way, sometimes even bending several times, or bending back or angularly towards the apex.

Various types of ribbing are seen in representatives of the genus. However, the characteristic feature of all of them is bending of the ribs in the vicinity of the symphysal margin as already mentioned and their convergence along 
at least a short part of the margin. This feature is always present, at least on juvenile valves. On the contrary, both Lamellaptychus and Beyrichilamellaptychus lack this feature. In contrast to Beyrichilamellaptychus, in which ribs also run along the symphysal margin, in representatives of Mortilletilamellaptychus the converging ribs never join to form a bundle of thin, closely spaced ribs, as found in the former genus.

When determining the new genus, the conception of its type species, M. mortilleti by Trauth (1938) turned out to be problematic. As stated below, to avoid confusion about the conception of the type species, we had to define another, morphologically relatively similar, new species, M. mortilletioides.

Species composition. - M. mortilleti (Pictet \& Loriol, 1858) and subspecies, M. mortilletioides sp. nov., M. mortilletinoricus (Trauth, 1938), M. submortilleti (Trauth, 1938) and subspecies, M. helveticus (Renz \& Habicht, 1985), M. stanislavi sp. nov., M. oceanicus (Renz, 1979), M. mendrisiensis (Renz \& Habicht, 1985) and subspecies, M. stellariformis (Renz, 1979), M. bicurvatus (Renz \& Habicht, 1985), M. beyrichodidayi (Trauth, 1938), etc.

Occurrence. - Late Tithonian to Late Valanginian.

\section{Mortilletilamellaptychus mortilleti \\ (Pictet \& Loriol, 1858) \\ Figure 9F}

?1857 Trigonellites Studeri Ooster; Ooster, p. 26, pl. 7, figs 3,6 .

1858 Aptychus Mortilleti (Pictet \& de Loriol); Pictet \& Loriol, p. 50, pl. 11, figs 9 b, d, 11, ?12, non fig. 10 (= ?Thorolamellaptychus noricus Winkler).

1938 Lamellaptychus mortilleti (Pict. \& Lor.) f. typ. Trauth, p. 145, pl. 10, figs 30, ?29, non figs 27,28 (=M. mortilletinoricus Trauth).

1961 Lamellaptychus submortilleti Trauth. - Stefanov, p. 219, pl. 3, fig. 6 .

1962b Lamellaptychus, group B, mortilleti (Pict. \& Lor.) f. typ. Trauth (partim). - Gąsiorowski, pl. 7, figs 7, 10.

1968 Lamellaptychus mortilleti (Pict. \& Lor.). - Jaksch, figs 10-12.

1979b Lamellaptychus mortilleti (Pictet \& Loriol). - Renz, p. 594, pl. 1, fig. 16 (refiguration of lectotype), figs 17-19, 22, ?20, ?21.

1985 Lamellaptychus mortilleti (Pictet \& Loriol). - Renz \& Habicht, p. 397, pl. 2, figs 2, 5, non pl. 1, figs 23-25, pl. 2, figs 1, 3, 4 (=M. mortilletioides $n$. sp.), non pl. 1, fig. 26 [= M. mortilletinoricus (Trauth)].

?1985 Lamellaptychus ticinensis new name. - Renz \& Habicht, pl. 4, fig. 3 . non 1994 Lamellaptychus mortilleti mortilleti (Pictet \& Loriol). - Vašíček et al., p. 72, pl. 23, fig. 9.

1995 Lamellaptychus (Lamellosuslamellaptychus) mortilleti mortilleti (Pictet \& Loriol). - Turculet \& Avram, p. 90 , pl. 1 , fig. 11 , pl. 2 , fig. 1 , non pl. 1 , figs $1-10$, figs $12-19$, pl. 2, figs $2-4$, figs $8-10$ (=M. mortilletioides n. sp.).

non 1996 Lamellaptychus mortilleti mortilleti (Pictet \& Loriol). - Vašíček, pl. 3, figs 3, ?4.

non 1996 Lamellaptychus mortilleti mortilleti (Pictet \& Loriol). - Eliáš et al., pl. 5, fig. 1 (= M. mendrisiensis Renz \& Habicht).

non 2000 Lamellaptychus mortilleti mortilleti (Pictet \& Loriol). - Boorová et al., pl. 14, fig. 10.

2000 Lamellaptychus mortilleti mortilleti (Pictet \& Loriol). - Vašíček et al., pl. 4, fig. 7.

Lectotype. - From the set of valves illustrated by Pictet \& Loriol (1858) under the name Aptychus mortilleti, Renz \& Habicht (1985) proposed the specimen illustrated in pl. 11, fig. $9 \mathrm{~b}$ as the lectotype.

Material. - A single valve (specimen V97-7c/11), published by Vašíček et al. (2000; pl. 4, fig. 7).

Description. - Vaulted valves, small in size with a welldeveloped keel and lateral depression. The keel makes an angle of about $30^{\circ}$ with the symphysal margin. Ribs in the zone of lateral depression can be slightly inflected. In the region of the keel, the ribs are arch-shaped. The majority of ribs end at the symphysal margin, usually at an angle of about $30^{\circ}$. However, before reaching this margin, they bend and adjoin it. Ribs along the shorter part of the symphysal margin thus converge towards the terminal point. Several adult ribs (usually 3 to 4 ) end at the outer margin.

Measurements. - The complete right valve of V97-7c/11 has the following dimensions: $\mathrm{L}=9.7 \mathrm{~mm}$, Lat $=4.4 \mathrm{~mm}$, $\mathrm{Lat} / \mathrm{L}=0.45$.

Remarks. - As already pointed out by Renz \& Habicht (1985), Trauth (1938) did not illustrate anything under the name Lamellaptychus mortilleti (Pictet \& Loriol), maybe with the exception of a juvenile valve in pl. 10, fig. 30 , in which the specimen is comparable with the lectotype as some of them belong to $M$. mortilletioides sp. nov. The latter species, to which the valves illustrated by Trauth (pl. 10, figs 27,28 ) also belong, differs from $M$. mortilleti especially in the ribs which are bent only in a very small area close to the symphysal margin and then immediately end at this margin. The juvenile specimen of Stefanov (1961, pl. 3, fig. 6) has strongly deformed valves, and thus the larger, more complete valve seems to be "rolled out" into the bedding plane. Thus it appears that neither keel nor lateral 
depression is present in the valve. Another valve, described by Trauth as L. mortilleti var. longa (1938, p. 147, pl. 10, figs 31,32 ) belongs to the category of slender specimens; similar valves were illustrated by Jaksch (1968, figs 17 , 18 ), and also by others. Whereas the stated specimens are generally characterized by narrow valves, in which Lat $/ \mathrm{L}$ is less than 0.40 , in other cases the valves are incompletely preserved or the valves were imperfectly measured (see e.g. Turculet \& Avram 1955, pl. 2, figs 11, 12, 14).

With regard to the imperfect quality of illustration, the valves that were determined by Turculet \& Avram (1995) as M. mortilleti mortilleti (Pictet \& Loriol), and also M. mortilleti longus (Trauth) form a problematic group from the point of view of detailed subspecific determination. Some of them surely belong to the type subspecies of M. mortilleti (Pictet \& Loriol), and some to M. mortilletinoricus (Trauth) and other subspecies of $M$. mortilleti (Pictet \& Loriol).

Occurrence. - According to the data of Renz \& Habicht (1985), in the Mediterranean area M. mortilleti occurs in the Late Berriasian and the Early part of the Valanginian.

In the Alpine-Carpathian area, true representatives of $M$. mortilleti were documented only in the Eastern Alps near Hollenstein a.d. Ybbs and in the Outer Western Carpathians in the locality of Kurovice, spanning from the Middle Berriasian to the Late Valanginian (ammonite Neocomites peregrinus Zone, Olcostephanus nicklesi Subzone).

\section{Mortilletilamellaptychus mortilletioides sp. nov. Figure 9G}

1968 Lamellaptychus mortilleti (Pict. \& Lor.). - Jaksch, fig. 31 .

1978 Lamellaptychus mortilleti (Pictet \& Loriol). - Renz, pl. 1, figs $3 \mathrm{a}, \mathrm{b}$.

1985 Lamellaptychus mortilleti (Pictet \& Loriol). - Renz \& Habicht, p. 397, pl. 1, figs 23-25, pl. 2, figs 1, 3, 4, non pl. 1, fig. 26 (= L. mortilletinoricus Trauth), non pl. 2, figs 2, 5 [= M. mortilleti (Pictet \& Loriol)].

1994 Lamellaptychus mortilleti mortilleti (Pictet \& Loriol). - Vašíček et al., p. 72, pl. 23, fig. 9.

1995 Lamellaptychus (Lamellosuslamellaptychus) mortilleti mortilleti (Pictet \& Loriol). - Turculet \& Avram, p. 90 , pl. 1 , figs $1-10$, figs $12-19$, pl. 2, figs $2-4$, figs $8-10$, non pl. 1, fig. 11, pl. 2, fig. 1 [= M. mortilleti (Pictet \& Loriol)].

1996 Lamellaptychus mortilleti mortilleti (Pictet \& Loriol). - Vašíček, pl. 3, figs 3, ?4.

1996 Lamellaptychus mortilleti radiatus Stefanov. - Vašíček, pl. 3, fig. 6 .

2000 Lamellaptychus mortilleti mortilleti (Pictet \& Loriol). - Boorová et al., pl. 14, fig. 10.
Holotype. - We regard a diaptychus designated in Vašíček et al. (1994, pl. 23, fig. 9) as Lamellaptychus mortilleti mortilleti (Pictet \& Loriol), here illustrated again in Pl. 2, fig. 7 as the holotype.

Derivatio nominis. - Mortilletioides - indicating similarity to the type species $M$. mortilleti.

Type locality. - Kurovice Quarry situated in the vicinity of the municipality of the same name.

Type horizon. - Tlumačov Marlstone, faunistic horizon D3, belonging to the calpionellid Calpionellites Zone, ?Calpionellites darderi Subzone, Early Valanginian.

Material. - Two perfectly preserved valves, forming a pair (specimen Ge00005).

Diagnosis. - The majority of the ribs end at the symphysal margin, immediately after bending closely to it.

Description. - Small valves with a keel and a lateral depression. In the lateral depression, the ribs are slightly inflected, and after the keel they are similarly bent towards the symphysal margin but in the opposite direction. Very close to the symphysal margin, the majority of the ribs bend towards the terminal point and end immediately. The last 1 or 2 ribs end at the outer margin. Sometimes radial lines developed.

Measurements. - The complete left valve has the following dimensions: $\mathrm{L}=11.7 \mathrm{~mm}$, Lat $=5.0 \mathrm{~mm}$, Lat $/ \mathrm{L}=0.43$.

Remarks. - Differences from the type species are given in the above-presented description. Trauth (1938) also described slender valves under the designation var. longa.

Occurrence. - In the Mediterranean area from the Middle Berriasian to the Late Valanginian, inclusively.

A single pair of valves from the Early Valanginian marlstone deposits in Kurovice Quarry (Moravia).

\section{Mortilletilamellaptychus mortilletinoricus (Trauth, 1938)}

Figure $9 \mathrm{H}$

1857 Trigonellites Studeri Ooster; Ooster, p. 26, pl. 7, figs 1 , ?6.

1867 Aptychus Seranonis Coquand. - Pictet, p. 123, pl. 28, figs $10 \mathrm{~b}$, c, non fig. 9 [= M. bicurvatus (Renz \& Habicht)].

1938 Lamellaptychus mortilleti-noricus n. f.; Trauth, p. 190, pl. 13, fig. 16. 
1938 Lamellaptychus mortilleti (Pictet \& Loriol) f. typ. Trauth, p. 145, pl. 10, figs 27, 28.

1962a L. mortilleti-noricus Trauth. - Gąsiorowski, p. 255, text-fig. 15 (fig. 25).

1962b Lamellaptychus, group B, mortilleti-noricus Trauth. - Gąsiorowski, pl. 7, fig. 1.

1968 Lamellaptychus mortilleti-noricus Trauth. - Jaksch, p. 113, figs $34,35, ? 33$.

1976 Lamellaptychus mortilleti-noricus Trauth. - Patrulius \& Avram, p. 193, pl. 10, fig. 16.

1985 Lamellaptychus ticinensis new name. - Renz \& Habicht, p. 409, pl. 3, figs 29, 31, pl. 4, fig. 1, non pl. 3, fig. 30, non pl. 4, fig. 3 [= M. mortilleti Pictet \& Loriol)], non fig. 2.

1985 Lamellaptychus mortilleti (Pictet \& Loriol). - Renz \& Habicht, p. 397, pl. 1, fig. 26.

1985 Lamellaptychus helveticus new name. - Renz \& Habicht, pl. 2, fig. 8 .

?1990 Lamellaptychus mortilleti noricus (Trauth). - Michalík et al., p. 88, pl. 5, fig. 7.

1996 Lamellaptychus mortilleti noricus Trauth. - Eliáš et al., pl. 5, fig. 2.

1996 Lamellaptychus mortilleti noricus Trauth. - Vašíček, pl. 3 , fig. 5 .

1997 Lamellaptychus ex gr. mortilleti noricus Trauth. Vašíček \& Hoedemaeker, p. 34, pl. 2, fig. 1.

2000 Lamellaptychus mortilleti noricus Trauth. - Vašíček et al., pl. 3, fig. 5 .

Holotype. - Lamellaptychus mortilleti-noricus Trauth (1938, pl. 13, fig. 16) on the basis of monotypy.

Material. - About 60 valves; Ge00008 is one of the best preserved specimens.

Description. - Small to large valves with a keel and a lateral depression. Thin, closely spaced ribs in the juvenile part correspond in arrangement to the type species $M$. mortilleti (Pictet \& Loriol). Final ribs follow exactly the outline of the outer margins of the valves. On small valves, only one to two final ribs can be found; with increasing size the number of ribs following the margin of the valve increases. Valves may reach a length of more than $25 \mathrm{~mm}$.

Measurements. - The left valve (Ge00008) has the following dimensions: $\mathrm{L}=21.8 \mathrm{~mm}$, $\mathrm{Lat}=10.6 \mathrm{~mm}$, $\mathrm{Lat} / \mathrm{L}=0.49$.

Remarks. - The holotype corresponds well morphologically to the valve that was illustrated by Pictet (1867, pl. 28, fig. 10). Renz \& Habicht (1985) considered their M. ticinensis Renz \& Habicht to be of the M. mortilletinoricus type, but without justification.

The last one or two ribs on large valves have a tendency to bend slightly backwards towards the apex in the vicinity of the symphysal margin, which indicates the transition to M. helveticus (Renz \& Habicht).

Occurrence. - According to Jaksch (1968), the mentioned subspecies occurs in Austria throughout the Berriasian to the Early Valanginian. Trauth's (1938) type specimen came from the Neocomian from the locality of Atmosgraben in the Austrian Alps. Vašíček et al. (1994) found the species in deposits along the Berriasian/Valanginian boundary in the Austrian Eastern Alps.

In the Outer Western Carpathians (Kurovice, Horné Srnie), Central Western Carpathians (Strážovce) and Northern Calcareous Alps (Tirolicum and Bajuvaricum) the first occurrences of the species have been found along the Early/Middle Berriasian boundary and to the Late Valanginian (ammonite Criosarasinella furcillata Zone).

\section{Mortilletilamellaptychus submortilleti (Trauth, 1938)}

Description. - Valves slightly vaulted, without a lateral depression or a keel. With the exception of the last few ribs, all ribs bend in the vicinity of the symphysal margin, converge along only a short section of it, and end at this margin. We have subdivided this species into two subspecies: $M$. s. submortilleti and M. s. noricus.

\section{Mortilletilamellaptychus submortilleti submortilleti (Trauth, 1938) \\ Figure 9I}

1938 Lamellaptychus sub-mortilleti n. n. f. typ.; Trauth, p. 143 , pl. 10 , figs $25, ? 24$, non fig. 23 (=M. s. noricus n. ssp.).

1962a L. sub-mortilleti Trauth, f. typ. - Gąsiorowski, p. 151, Figure 14 (fig. 14).

1968 Lamellaptychus sub-mortilleti Trauth. - Jaksch, p. 109, figs 3-5.

1979 Lamellaptychus submortilleti Trauth. - Kälin et al., p. 755 , figs $11 \mathrm{~h}, 1, \mathrm{~m}, \mathrm{q}, \mathrm{r}, \mathrm{s}$.

1979b Lamellaptychus submortilleti Trauth. - Renz, p. 594, pl. 1, figs 25, 26, ?23, ?24.

?1993 Lamellaptychus submortilleti Trauth. - Michalík et al., pl. 2, fig. 5.

1994 Lamellaptychus submortilleti Trauth. - Vašíček et al., p. 71, pl. 23, fig. 5 .

1996 Lamellaptychus submortilleti Trauth. - Eliáš et al., pl. 4 , fig. 8 .

1996 Lamellaptychus submortilleti Trauth. - Vašíček, pl. 2, fig. 2.

1996 Lamellaptychus sub-mortilleti Trauth. - Jaksch, pl. 1, fig. 11. 
Lectotype. - Of the set of valves described and illustrated by Trauth (1938), we propose a valve designated as Lamellaptychus sub-mortilleti n. n. f. typ., illustrated by Trauth in pl. 10, fig. 25 as the lectotype. It is deposited in Trauth's collections in the Natural History Museum in Vienna.

Material. - Eight valves with various levels of preservation. Specimen Ge00006 is one of the best preserved.

Description. - Slightly vaulted valves of medium size. The last few ribs end at the outer margin.

Measurements. - The almost complete right valve of Ge00006 has the following dimensions: $\mathrm{L}^{\prime}=22.0 \mathrm{~mm}$, Lat' $=13.0 \mathrm{~mm}$.

Remarks. - Ribbing resembles $M$. mortilleti. One difference is that the vaulted valves of $M$. mortilleti have keels and lateral depressions. In addition to the type subspecies, forms in which the last few ribs do not end at the outer margin but follow the outline of the valve also occur. They are described below as $M$. s. noricus n. ssp.

Occurrence. - Jaksch (1968) and Vašíček et al. (1994) reported a distribution from the Tithonian to the Early Valanginian.

We found M. s. submortilleti in deposits of the Late Tithonian (calpionellid Crassicollaria Zone, Crassicollaria colomi Subzone) and up to Middle Berriasian age (calpionellid Calpionella Zone, Calpionella elliptica Subzone) in the Western Carpathians and Northern Calcareous Alps.

\section{Mortilletilamellaptychus submortilleti noricus ssp. nov.} Figure 9J

1938 Lamellaptychus sub-mortilleti n. n. f. typ.; Trauth, p. 143, pl. 10, fig. 23 , non figs 24,25 [= M. s. submortilleti (Trauth)].

?1985 Lamellaptychus submortilleti Trauth. - Renz \& Habicht, p. 395, pl. 1, figs 12, 14.

1979 Lamellaptychus submortilleti Trauth. - Kälin et al., p. 755 , fig. 11f.

1995 Lamellaptychus submortilleti Trauth. - Reháková et al., p. 57, pl. 2, fig. 8 .

2000 Lamellaptychus submortilleti Trauth. - Boorová et al., pl. 13, fig. 8 .

Holotype. - Valve illustrated by Trauth (1938) in pl. 10, fig. 23 under the name of Lamellaptychus sub-mortilleti. It is deposited in Trauth's collections in the Natural History Museum in Vienna.
Derivatio nominis. - According to the arrangement of adult ribs, resembling Mortilletilamellaptychus mortilletinoricus (Trauth) in ribbing.

Type horizon and locality. - According to Trauth (1938) Arrach Quarry near Steinmühl, south-east of Waidhofen a. d. Ybbs, Tithonian to the "Neocomian".

Material. - A single well-preserved valve, Ge00007 and two other incomplete valves.

Diagnosis. - Simple ribs follow the outline of the valves. Ribs are S-shaped in the vicinity of the symphysal margin. The last adult rib or ribs follow the external outline of the valve and thus end at the terminal point.

Description. - Slightly vaulted valve without a keel or a lateral depression. Juvenile ribs are of the "mortilleti" type, and in the near-symphysal area are S-shaped. Final ribs follow the external outline of the valve.

Measurements. - The almost complete right valve of Ge00007 has the following dimensions: $\mathrm{L}^{\prime}=13.8 \mathrm{~mm}$, Lat' $=7.4 \mathrm{~mm}$.

Remarks. - M. s. submortilleti (Trauth) and M. s. noricus n. ssp. represent morphologically similar but distinguishable subspecies. The ribbing of the latter subspecies resembles, to a certain extent, M. mortilletinoricus (Trauth). M. submortilleti (Trauth) clearly differs from M. mortilleti (Pictet $\&$ Loriol) and M. mortilletinoricus (Trauth) by the absence of a keel and lateral depression.

Occurrence. - Trauth's (1938) holotype comes from the Austrian Klippen Belt near Waidhofen. Renz \& Habicht (1985) reported their valves of ambiguous classification to be from the Late Tithonian. Valves of $M$. s. noricus have also been found in the Austrian Eastern Alps, in the Schrambach Formation, south of Salzburg (Early/Middle Berriasian - Boorová et al. 2000).

M. s. noricus has been found in Early Berriasian strata in the Outer Western Carpathians (localities of Kurovice and Vigantice).

\section{Mortilletilamellaptychus helveticus (Renz \& Habicht, 1985)}

Figure 9K

1985 Lamellaptychus helveticus new form; Renz \& Habicht, p. 398, pl. 2, fig. 7, non fig. 8 (= M. mortilletinoricus Trauth), non fig. 9.

1985 Lamellaptychus retroflexus Trauth. - Renz \& Habicht, p. 402, pl. 2, fig. 28. 
1996 Lamellaptychus helveticus Renz \& Habicht. - Vašíček, pl. 5, fig. 3.

Lectotype. - Of the set of valves illustrated by Renz \& Habicht (1985), only the valve in pl. 2, fig. 7, complies with the species description and we propose it as the lectotype.

Material. - Two incomplete valves from the locality of Kurovice. One is nothing more than a fragment (illustrated in Vašíček 1996, pl. 5, fig. 3), but the specimen Ge00009 is almost complete.

Description. - Valves of medium size with a welldeveloped keel. Juvenile ribs are of the "mortilleti" type. Near the symphysal margin, adult ribs slightly incline back to the apex and follow the outline of the valve.

Measurements. - The incomplete left valve of Ge00009 has the following dimensions: L' $=23.2 \mathrm{~mm}$ and Lat' $=$ $9.6 \mathrm{~mm}$.

Remarks. - Valves of M. helveticus (Renz \& Habicht) are very similar in the arrangement of ribs to M. mortilletinoricus (Trauth). However, they differ by a slight inclination of the last few ribs back towards the apex. They can be regarded as an independent species, because same size or larger valves of $M$. mortilletinoricus (Trauth) lack the backwards bend. On juvenile valves, the abovementioned characteristic feature are not yet developed. Final ribs may resemble $T$. bermudensis (Renz) in arrangement. But juvenile ribs of the latter species are of the "thoro" type. Almost identical ribbing can be observed in M. beyrichodidayi (Trauth). Nevertheless, ribs of this representative are coarser and spaced further apart from each other, and their backwards bending is more conspicuous, even angular, compared to M. helveticus (Renz \& Habicht) described here.

Occurrence. - According to Renz \& Habicht (1985), M. helveticus (Renz \& Habicht) occurred in the Late Berriasian and in the Early Valanginian.

M. helveticus has been found only in the locality of Kurovice (Outer Western Carpathians) in Early Valanginian deposits (calpionellid Calpionellites Zone, ?Calpionellites darderi Subzone).

\section{Mortilletilamellaptychus stanislavi sp. nov.}

Figure 9L

?1978 Lamellaptychus lorioli; Renz, p. 904, pl. 1, figs 6a, b. 1985 Lamellaptychus aff. retroflexus Trauth. - Renz \& Habicht, pl. 2, figs 25, 26.
?1985 Lamellaptychus retroflexus Trauth. - Renz \& Habicht, p. 402, pl. 2, fig. 32.

1994 Lamellaptychus lorioli Renz. - Vašíček et al., p. 73, pl. 24, fig. 4.

1996 Lamellaptychus lorioli Renz. - Vašíček, pl. 5, fig. 2.

Holotype. - The valve illustrated in Vašíček et al. (1994) in pl. 24, fig. 4, illustrated here again as Fig. 9L is selected as the holotype. The valve will be deposited in the collections of the Department of Geology and Palaeontology of the Moravian Museum in Brno under the number Ge00010.

Derivatio nominis. - According to the old Slavonic name Stanislav - in honour of Stanislav Hrouzek senior, Stanislav Hrouzek junior and Stanislav Benada, who participated significantly in field collections in the locality of $\mathrm{Ku}-$ rovice.

Type locality. - Kurovice Quarry, near the municipality of Kurovice.

Type horizon. - Tlumačov Marlstone, Early Valanginian (Calpionellites Zone).

Material. - Eleven generally incomplete valves. The holotype is one of the best-preserved valves.

Diagnosis. - Simple initial ribs; near the symphysal margin they bend angularly back towards the apex.

Description. - Valves of small to medium size with a conspicuous keel and a lateral depression. Juvenile ribs are of the "mortilleti" type. Adult ribs, characterized by the sublinear arrangement on the flanks of the valve, bend closely to the symphysal margin, subangularly to angularly back towards the apex. They hold this position over the whole length of the valve as far as the terminal point.

Measurements. - The incomplete holotype (left valve) has the following dimensions: $\mathrm{L}^{\prime}=17.2 \mathrm{~mm}$ and Lat' $=8.3 \mathrm{~mm}$.

Remarks. - The angular bending of ribs of M. stanislavi distinguishes this species from all other representatives of M. ex gr. mortilleti.

Occurrence. - Renz \& Habicht's valves (1985) came from the Valanginian of south Switzerland.

The species has been found in the Early Valanginian localities (in the calpionellid Calpionellites Zone and in the ammonite Busnardoites campylotoxus Zone) in the Outer Western Carpathians (Kurovice) and Central Western Carpathians (Butkov). 


\section{Mortilletilamellaptychus oceanicus (Renz, 1979)} Figure 9M

1979b Lamellaptychus oceanicus n. sp.; Renz, p. 593, pl. 1, figs $11 \mathrm{a}, \mathrm{b}$.

Holotype. - Lamellaptychus oceanicus n. sp. in Renz (1979b, pl. 1, fig. 11a).

Material. - Four specimens. Specimen SNM-Z24890 is one of the best preserved.

Description. - Small valves with an indistinct keel and a missing lateral depression (probably due to specimen incompleteness). The ribs are fine and relatively closely spaced. In the near-symphysal area, they are of the "mortilleti" type. In the terminal zone, ribbing is more complicated the last three to four ribs are sharply S-shaped and end close to each other around the terminal point.

Measurements. - The very incomplete right valve (spec. SNM-Z24890) has the following dimensions: $\mathrm{L}^{\prime}=$ $15.2 \mathrm{~mm}$ and Lat' $=8.5 \mathrm{~mm}$.

Remarks. - The valve described here differs from the holotype illustrated by Renz (1979b) in its ribs, which are not well developed and which follow the external outline of the valve.

A certain similarity to $M$. mendrisiensis undulocostatus, which was described by Boorová et al. (2000) can be observed. The inflection of ribs of M. m. undulocostatus (Boorová, Lobitzer, Skupien \& Vašíček) parallels the symphysal margin (from the apical area to the outer margin), whereas the S-shaped bend in M. oceanicus Renz is developed only in the last few ribs in the terminal area. In some cases, radial lines can also be present.

Occurrence. - Renz (1979b) reported its distribution as in the Berriasian (west part of North Atlantic).

M. oceanicus has been found only in the Late Valanginian localities (ammonite Neocomites peregrinus Zone) in the Outer Western Carpathians (Revišné locality, Slovakian Klippen Belt), Central Western Carpathians (Strážovce locality) and Northern Calcareous Alps (area of Enns River near Grossraming).

\section{Mortilletilamellaptychus mendrisiensis (Renz \& Habicht, 1985)}

Description. - Valves are characterized by the convergence of ribs along a rather long section of the symphysal margin. Final ribs run straight to the outer margin where they end and do not bend as with valves of $M$. mortilleti (Pictet \&
Loriol). This species is divided here into two subspecies: M. m. mendrisiensis and M. m. undulocostatus.

\section{Mortilletilamellaptychus mendrisiensis mendrisiensis (Renz \& Habicht, 1985) \\ Figure 9N}

1961 Lamellaptychus mortilleti (Pictet \& Loriol), var. longa Trauth. - Stefanov, p. 218, pl. 3, fig. 2.

1985 Lamellaptychus mendrisiensis new form; Renz \& Habicht, p. 411, pl. 4, fig. 9.

?1994 Lamellaptychus mendrisiensis Renz \& Habicht. Vašíček et al., p. 72, pl. 23, fig. 11.

1996 Lamellaptychus mendrisiensis mendrisiensis Renz \& Habicht. - Vašíček, pl. 5, fig. 1.

2000 Lamellaptychus mendrisiensis mendrisiensis Renz \& Habicht. - Boorová et al., pl. 14, figs 11, 12.

Holotype. - Lamellaptychus mendrisiensis new form in Renz \& Habicht (1985, pl. 4, fig. 9), on the basis of monotypy.

Material. - Twelve valves. Specimen SNM-Z24891 is one of the best preserved.

Description. - Valves of small to medium size, with a conspicuous keel and a lateral depression. Ribs between the keel and the symphysal margin are relatively straight. They run obliquely towards the symphysal margin. In its vicinity, they are S-shaped and converge along a long section of the margin. Several final ribs end straight at the outer margin.

Measurements. - The left valve (SNM-Z24891) is incomplete. Its dimensions are as follows: $\mathrm{L}^{\prime}=13.2 \mathrm{~mm}$ and Lat' $=6.4 \mathrm{~mm}$.

Remarks. - Juvenile ribs resemble $M$. mortilleti (Pictet $\&$ Loriol) in their ribbing. The subsequent ribs are slightly $\mathrm{S}$-shaped in the vicinity of the symphysal margin, and converge along a rather long stretch of it. The final ribs of $M . m$. mendrisiensis are not S-shaped in the vicinity of the symphysal margin, but converge on it in a straight line.

Within the framework of M. mendrisiensis (Renz \& Habicht), the subspecies M. m. undulocostatus (Boorová, Lobitzer, Skupien \& Vašíček) has recently been determined. It differs from the typical subspecies by complicated ribbing in the vicinity of the symphysal margin.

Occurrence. - Renz \& Habicht (1985) reported distribution in the Late Valanginian of Switzerland, Vašíček et al. (1994) the Late Valanginian, and also maybe the Early 
Hauterivian of Central Carpathians in Slovakia. Boorová et al. (2000) reported their findings from the Austrian Eastern Alps, from the lower part of the Late Valanginian.

The subspecies has been found in Late Valanginian localities in the Outer Western Carpathians (Horné Srnie, Revišné), Central Western Carpathians (Strážovce) and Northern Calcareous Alps (Tirolicum and Bajuvaricum).

\section{Mortilletilamellaptychus mendrisiensis undulocostatus Boorová, Lobitzer, Skupien \& Vašíček, 2000 Figure 10A}

2000 Lamellaptychus mendrisiensis undulocostatus n. ssp.; Boorová et al., p. 312, pl. 14, fig. 13.

Holotype. - Lamellaptychus mendrisiensis undulocostatus n. ssp. in Boorová et al. (2000, pl. 14, fig. 13).

Material. - A single, very well preserved valve (specimen GBA 2009/007/1 - holotype).

Description. - Valve of small to medium size, with a keel and a lateral depression. Below the keel, in the area of the depression, ribs are inflected. They continue straight up to the near-symphysal area, where they sharply undulate several times along the whole length of the symphysal margin. Immediately below the symphysal margin, these ribs converge with it.

Measurements. - The dimensions of the completely preserved holotype (right valve) are as follows: $\mathrm{L}=14.1 \mathrm{~mm}$ and Lat $=7.4 \mathrm{~mm}$, Lat $/ \mathrm{L}=0.52$.

Remarks. - Typical M. m. mendrisiensis differs from the subspecies defined by Boorová et al. (2000) by the simplicity of ribbing in the vicinity of the symphysal margin.

Occurrence. - The holotype (Boorová et al. 2000) comes from the Gutrathsberg Quarry near Gartenau in the Northern Calcareous Alps (Tirolicum), from the lower part of the Rossfeld Formation (early Late Valanginian).

\section{Mortilletilamellaptychus stellariformis (Renz, 1978) Figure 10B}

1978 Lamellaptychus stellariformis n. sp.; Renz, p. 904, pl. 1 , fig. 9 , text-fig. 3 .

1996 Lamellaptychus stellariformis Renz. - Eliáš et al., pl. 5 , fig. 4.

1996 Lamellaptychus stellariformis Renz. - Vašíček, pl. 3, fig. 7.
Holotype. - Lamellaptychus stellariformis in Renz (1978), illustrated in pl. 1, fig. 9.

Material. - One incomplete valve (Ge00011).

Description. - If completely preserved, the length of the valve would probably not exceed $20 \mathrm{~mm}$, and thus the valve would be classed as a small valve. The final ribs follow the external outline of the valve and bend towards the symphysal margin at approximately a right angle. At the terminal point, the last ribs are a complicated S-shape in the immediate vicinity of the symphysal margin.

Measurements. - A fragment of the right valve has the following dimensions: $\mathrm{L}^{\prime}=12.4 \mathrm{~mm}$ and Lat' $=7.2 \mathrm{~mm}$.

Remarks. - The illustration of the holotype by Renz (1978) is of poor quality. Morphological features are clearly illustrated by Eliáš et al. (1994, pl. 5, fig. 4).

Occurrence. - Renz (1978) reported distribution in the Valanginian, in the Blake-Bahama Basin (West Atlantic).

A single representative of the species was found in Early Valanginian deposits (calpionellid Calpionellites Zone, ?Calpionellites darderi Subzone) in the locality of Kurovice (Outer Western Carpathians).

\section{Mortilletilamellaptychus bicurvatus (Renz \& Habicht, 1985) \\ Figure 10C}

1867 Aptychus Seranonis Coquand; Pictet, pl. 28, fig. 9b.

1938 Lamellaptychus submortilleti $\mathrm{n}$. n. var. n. retroflexa. - Trauth, p. 201, pl. 14, fig. 6.

1938 Lamellaptychus seranonis (Coquand) f. typ. - Trauth, pl. 13, fig. 29.

1961 Lamellaptychus mortilleti (Pictet \& Loriol). - Stefanov, p. 217, pl. 3, fig. 1.

1985 Lamellaptychus bicurvatus new name. - Renz \& Habicht, p. 409, pl. 3, figs 25-28.

1994 Lamellaptychus bicurvatus Renz \& Habicht. - Vašíček et al., p. 73, pl. 23, fig. 13.

1996 Lamellaptychus bicurvatus Renz \& Habicht. - Vašíček, pl. 5, fig. 5.

?1996 Lamellaptychus trauthi Renz \& Habicht. - Vašíček, pl. 4 , fig. 7.

1996 Lamellaptychus bicurvatus Renz \& Habicht. - Vašíček \& Faupl, p. 113, pl. 4, fig. 10.

1998 Lamellaptychus trauthi Renz \& Habicht. - Vašíček \& Faupl, pl. 1, fig. 6.

Holotype. - Renz \& Habicht (1985) assigned the specimen designated by Trauth (1938) as Lamellaptychus sub-mor- 
tilleti var. retroflexa, illustrated by Trauth (1938) in pl. 14, fig. 6 , as the holotype.

Material. - Nine valves. The valve SNM-Z24903 is one of the best preserved.

Description. - Valves medium in size. Juvenile ribs converge along the symphysal margin. Several final ribs bend subangularly to angularly back towards the apex. Subsequently, in the near-symphysal area, the direction in which the ribs run changes and the ribs briefly orientate towards the terminal point. On some valves, radial lines can be observed.

Measurements. - The incomplete left valve of specimen SNM-Z24903 has the following dimensions: L' $=22.0 \mathrm{~mm}$ and Lat' $=11.5 \mathrm{~mm}$.

Remarks. - A series of valves, illustrated by Renz \& Habicht (1985), characterizes M. bicurvatus better than Trauth's type specimen. The best valve in Renz \& Habicht's sample (1985) is represented by the specimen in fig. 26, pl. 3.

M. bicurvatus is similar to Thorolamellaptychus lombardicus (Renz \& Habicht, 1985). The difference between them is that juvenile ribs of M. bicurvatus, in contrast to T. lombardicus, are of the "mortilleti" type. There is a clear similarity between the species described here and M. beyrichodidayi (Trauth). M. bicurvatus differs from it by the subangular to angular bend of the ribs in the direction of the apex of the valve and then a short S-shaped bend in the vicinity of the symphysal edge, at which point the ribs lead towards the terminal point.

Occurrence. - The specimens of Renz \& Habicht (1985) occurred in Late Valanginian deposits (Breggia area, south Switzerland). In addition, findings from the Rossfeld Formation (Northern Calcareous Alps) are of Late Valanginian age (Vašíček \& Faupl 1996).

The species has been found in the Late Valanginian (from the ammonite Saynoceras verrucosum Zone to the boundary between the Neocomites peregrinus and the Criosarasinella furcillata Zones) of the Outer Western Carpathians (localities of Horné Srnie, Revišné), Central Western Carpathians (Butkov Quarry) and Northern Calcareous Alps (Bajuvaricum).

\section{Mortilletilamellaptychus beyrichodidayi (Trauth, 1938) Figure 10D}

1938 Lamellaptychus beyricho-didayi n. f.; Trauth, p. 200, pl. 14 , fig. 5.

non 1962a L. beyrichodidayi Trauth. - Gąsiorowski, p. 252, pl. 14, fig. 27 (= Beyrichilamellaptychus sp.). non 1962b Lamellaptychus, group A, beyricho-didayi Trauth. Gąsiorowski, pl. 7, fig. 6 (=Beyrichilamellaptychus sp.).

1985 Lamellaptychus angulodidayi Trauth. - Renz \& Habicht, pl. 4, fig. 7.

1994 Lamellaptychus beyrichodidayi Trauth. - Vašíček et al., p. 73 , pl. 24, fig. 1.

1996 Lamellaptychus beyrichodidayi Trauth. - Vašíček, pl. 5 , fig. 4 .

Holotype. - On the basis of monotypy, the specimen designated as Lamellaptychus beyricho-didayi in Trauth (1938), illustrated in pl. 14, fig. 5, is selected as the holotype.

Material. - Eleven valves with various levels of preservation. Specimen SNM-Z24895 is one of the best preserved.

Description. - Valves medium to large in size. In spite of the imperfect preservation, a keel, shallow lateral depression and relatively large width of the valves are conspicuously visible. Juvenile ribs are straighter. Later ribs converge along a short section of the symphysal margin. This type of ribbing changes very quickly into ribs which bend in an arch-like manner back towards the apex. Some valves may bear radial lines.

Measurements. - The dimensions of the right valve (SNM-Z24895) are as follows: $\mathrm{L}=25.5 \mathrm{~mm}$, Lat $=13.4 \mathrm{~mm}$, $\mathrm{Lat} / \mathrm{L}=0.52$.

Remarks. - M. beyrichodidayi (Trauth) is, according to Trauth (1938), a representative of a group having common features with the species B. beyrichi (Oppel) and D. didayi (Coquand).

In our opinion, the type specimen of the species illustrated by Trauth (1938) does not have juvenile ribs of the "beyrichi" type, because the ribs do not form any bundle converging along the symphysal margin. Instead, its ribs belong to the "mortilleti" type (as also demonstrated by the rich paleontological material found in the localities studied). With regard to the rule of priority, it is necessary however to adhere to the original name.

Under the name L. beyrichodidayi, Gąsiorowski (1962a, b) illustrated valves with rib discordance which is not known in this group. This probably represents a new species within the Beyrichilamellaptychus.

Occurrence. - Trauth (1938) reported distribution in the Neocomian in the area of Barrême (Basses Alpes) and Vašíček (1996) the Late Valanginian of the Western Carpathians.

The stratigraphic range of this species is from localities of Early Valanginian (ammonite Busnardoites campylotoxus Zone) to the Late Valanginian (ammonite 
Neocomites peregrinus Zone) age from the Outer Western Carpathians (localities of Horné Srnie, Revišné) and Central Western Carpathians (localities of Butkov and a nameless brook below Mráznica Hill).

\section{Genus Thorolamellaptychus Turculet, 1994}

Type species. - Aptychus Thoro Oppel, 1863.

Description. - Ribs both in the juvenile and the adult stage follow the shape of the valves. All ribs or almost all of them end at the symphysal margin (Fig. 7G). The final developmental stages may show rather complicated ribbing.

Species composition. - Thorolamellaptychus thoro (Oppel, 1863), T. aplanatus (Gilliéron, 1873) and subspecies, T. noricus (Winkler, 1868), T. lorioli (Renz, 1979), T. symphysocostatus (Trauth, 1938), T. bermudensis (Renz, 1979), T. trauthi (Renz \& Habicht, 1985), T. lombardicus (Renz \& Habicht, 1985), etc.

Occurrence. - ?Oxfordian to Late Valanginian.

\section{Thorolamellaptychus aplanatus (Gilliéron, 1873)}

Description. - Vaulted valves without a lateral depression or with only the suggestion of a lateral depression. All or almost all ribs end at the symphysal margin. They do not show any complication within the simple arrangement. The species is divided into three subspecies: T. a. aplanatus, T. a. latus (Vašíček, Michalík, Reháková, 1994) and T. a. retroflexus (Trauth, 1938). T. a. aplanatus and T. a. latus are described in Vašíček et al. (1994).

\section{Thorolamellaptychus aplanatus retroflexus (Trauth, 1938)}

Figure 10E

1938 Lamellaptychus aplanatus (Gill.) var. n. retroflexa; Trauth, p. 193, pl. 13, figs 24, 25.

?1977 Lamellaptychus aplanatus (Gilliéron). - Renz, p. 504, pl. 1, figs 25a, b.

1979b Lamellaptychus aplanatus retroflexus Trauth. Renz, p. 387, pl. 1, figs 3a, b.

1979b Lamellaptychus ?aplanatus retroflexus Trauth. Renz, p. 397, pl. 1, figs 8a, b.

1983 Lamellaptychus aplanatus retroflexus Trauth. Renz, pl. 1, fig. 14.

1985 Lamellaptychus retroflexus Trauth. - Renz \& Habicht, p. 402, pl. 2, figs 30, 31, ?27-29, non fig. 32 [= M. stanislavi $\mathrm{n} . \mathrm{sp})$.$] .$
Holotype. - Lamellaptychus aplanatus (Gill.) var. n. retroflexa in Trauth (1938, pl. 13, fig. 24).

Material. - Seven specimens of valves of aptychi. Specimen SNM-Z24892 is one of the best preserved.

Description. - Small vaulted valves, triangular shaped, with a keel and a shallow lateral depression. Ribs are closely spaced and fine. Juvenile ribs converge at the symphysal margin at an angle of about $80^{\circ}$. Adult ribs have a tendency to bend back towards the apical area of the valve.

Measurements. - A completely preserved right valve has the following dimensions: $\mathrm{L}=9.3 \mathrm{~mm}$, Lat $=5.6 \mathrm{~mm}$, $\mathrm{Lat} / \mathrm{L}=0.60$.

Remarks. - In view of the ribbing, this subspecies is similar to $T$. lorioli (Renz). Valves of $T$. a. retroflexus (Trauth) are, however, smaller and the ribs are not bent in such a broad arch as in T. lorioli (Renz). Valves of $T$. lorioli (Renz) are narrower; valves of $T$. aplanatus retroflexus (Trauth) become markedly narrower towards the terminal part.

Due to the intensity of the backwards bend of the ribs Renz \& Habicht (1985) did not agree with the classification of this subspecies into the T. aplanatus group. The set of valves examined by those authors was however variable. A number of their small valves (stated in synonymics) have juvenile ribs of the "thoro" type. We thus classify them as T. a. retroflexus and the ribs as juvenile ribs as in some other adult valves.

Occurrence. - Renz (1977) reported distribution in the uppermost part of the Tithonian (Atlantic), Renz (1983) in the Valanginian and Renz \& Habicht (1985) from the Late Tithonian to the Early Valanginian.

The stratigraphic range of the subspecies is from localities of Early Valanginian (ammonite Busnardoites campylotoxus Zone) to Late Valanginian (ammonite Neocomites peregrinus Zone, Olcostephanus nicklesi Subzone) age in the Outer Western Carpathians (Revišné) and Central Western Carpathians (Butkov).

\section{Thorolamellaptychus noricus (Winkler, 1868)}

Figure 10F, G

1868 Aptychus noricus Winkler; Winkler, p. 27, pl. 4, fig. 14.

1938 Lamellaptychus noricus (Wkl.). - Trauth, p. 189, pl. 13, figs $14,15$.

1968 Lamellaptychus noricus (Wkl.). - Jaksch, p. 113, figs $50-60$. 
1996 Lamellaptychus noricus (Winkler). - Vašíček, fig. $2 / 37$.

1996 Lamellaptychus noricus (Winkler). - Vašíček, pl. 4, fig. 1.

Holotype. - A single valve, $17 \mathrm{~mm}$ long, with a small part of the terminal margin missing, designated by Winkler (1868) as Aptychus noricus, illustrated in pl. 4, fig. 14.

Material. - Two complete valves (SNM-Z24896 and SNM-Z24897). The original material of the second specimen was split off from the rock base in several places.

Description. - Usually small sized valves, strongly elongated, without a lateral depression. All ribs run simply parallel to the periphery of the valve, and thus all end at the symphysal margin.

Measurements. - The left valve, extraordinary large in size (SNM-Z24897) has the following dimensions: $\mathrm{L}=45.0 \mathrm{~mm}$, Lat $=15.3 \mathrm{~mm}$, Lat $/ \mathrm{L}=0.34$. The dimensions of SNM-Z24986 are as follows: $\mathrm{L}=13.7 \mathrm{~mm}$, Lat $=6.5 \mathrm{~mm}$, $\mathrm{Lat} / \mathrm{L}=0.48$.

Remarks. - Usually valves are about 10 to $17 \mathrm{~mm}$ in size. One of the valves of $T$. noricus from the Slovak Carpathians is of unusual size: $45 \mathrm{~mm}$. Ribbing is the same all over the valve. Very similar to T. noricus is T. aplanatus aplanatus (Gilliéron), which has almost the same ribbing. The last and in some cases oldest adult ribs of the similar species, however, end at the terminal edge. Valves of T. aplanatus aplanatus are considerable wider, with a Lat/L ratio of more than 0.50 .

Occurrence. - T. noricus is known from the Northern Calcareous Alps. Jaksch (1968) reported distribution from the Early Valanginian to the Hauterivian.

The described valves come from the uppermost part of the Early Valanginian and the lower part of Late Valanginian deposits from the Butkov Quarry. Incomplete, not always unambiguously determinable valves occur at Butkov only in the Valanginian strata.

\section{Thorolamellaptychus lorioli (Renz, 1979)}

Figure $10 \mathrm{H}$

non 1978 Lamellaptychus lorioli Renz; Renz, p. 904, pl. 1, figs $6 \mathrm{a}, \mathrm{b}$ (= ?M. stanislavi n. sp.).

1979b Lamellaptychus lorioli n. sp.; Renz, p. 593, pl. 1, figs $5 \mathrm{a}, \mathrm{b}$.

?1985 Lamellaptychus lorioli Renz. - Renz \& Habicht, p. 398, pl. 2, fig. 6 .

non 1994 Lamellaptychus lorioli Renz. - Vašíček et al., p. 73, pl. 24, fig. 4 (= M. stanislavi $\mathrm{n}$. sp.). non 1996 Lamellaptychus lorioli Renz. - Vašíček, pl. 5, fig. 2 (= M. stanislavi n. sp.).

1996 Lamellaptychus cf. lorioli Renz. - Vašíček \& Faupl, pl. 4 , fig. 9 .

2000 Lamellaptychus symphysocostatus Trauth. - Vašíček \& Faupl, pl. 1, fig. 4.

Holotype. - Lamellaptychus lorioli n. sp.; Renz (1979b, pl. 1, fig. 5a).

Material. - Six incompletely preserved valves. Specimen V95-8/3 is the best preserved.

Description. - Medium-sized valves (usually exceeding a length of $20 \mathrm{~mm}$ ), with a keel and probably also a lateral depression. Ribs are relatively widely spaced and rather strong. Juvenile ribs are subangularly bent near the symphysal margin. They bend towards the symphysal margin at an angle of about $50^{\circ}$. Adult ribs bend in the vicinity of the symphysal margin back towards the apex in an arch-like manner. The last ribs near the terminal point may be incomplete.

Measurements. - The complete and well-preserved left valve of V95-8/3 has the following dimensions: $\mathrm{L}=$ $15.1 \mathrm{~mm}$ and $\mathrm{Lat}=7.0 \mathrm{~mm}, \mathrm{Lat} / \mathrm{L}=0.46$.

Remarks. - With regard to the fact that the true holotype and the original description of T. lorioli (Renz) were, due to a delay in press, published by Renz a year later (1979b) than the illustration of a valve with the same name but with different ribbing (Renz 1978), erroneous interpretation of the species occurred in the contribution by Vašíček et al. (1994). In this paper, we have made an attempt to correct this mistake (see synonymics).

The described material resembles $T$. aplanatus retroflexus (Trauth). A difference between the two taxa is mentioned in the remarks concerning the subspecies. Into the synonymics of $T$. lorioli, Renz (1979b) erroneously classified an imperfectly preserved valve of Aptychus seranonis Coquand, illustrated in Pictet (1867, pl. 28, fig. 9b). However, this valve corresponds in overall morphology with $M$. bicurvatus (Renz \& Habicht), because it bears juvenile ribs of the "mortilleti" type.

Occurrence. - Renz \& Habicht (1985) reported distribution in the Late Berriasian and the Early Valanginian of Switzerland (area of Breggia, southern Switzerland).

The stratigraphic range of the species is from the later part of the Early Valanginian to the boundary between the Late Valanginian ammonite Neocomites peregrinus and Criosarasinella furcillata Zones in the Central Western Carpathians (Butkov) and Northern Calcareous Alps (Bajuvaricum). 


\section{Thorolamellaptychus symphysocostatus (Trauth, 1938)} Figure 10I

1938 Lamellaptychus angulocostatus (Pet.) var. n. symphysocostata; Trauth, p. 208, pl. 14, figs 15, 16.

1968 Lamellaptychus angulocostatus (Pet.) var. n. symphysocostata Trauth. - Jaksch, p. 118, fig. 88.

1985 Lamellaptychus symphysocostatus Trauth. - Renz \& Habicht, p. 406, pl. 3, figs 12-14.

1994 Lamellaptychus symphysocostatus (Trauth). - Vašíček et al., p. 77, pl. 24, figs 2, 3.

1996 Lamellaptychus symphysocostatus Trauth. - Vašíček, pl. 4 , fig. 2.

non 2000 Lamellaptychus symphysocostatus Trauth. - Vašíček \& Faupl, p. 614, pl. 1, fig. 4 (= T. lorioli Renz).

2000 Lamellaptychus symphysocostatus Trauth. - Boorová et al., p. 312, pl. 14, fig. 14.

Holotype. - Lamellaptychus angulocostatus (Pet.) var. n. symphysocostata in Trauth (1938, pl. 14, figs 15, 16).

Material. - Three favourably preserved specimens. The valve of specimen SNM-Z21166 is the best preserved.

Description. - Vaulted valves of small to medium size. Ribs bend in a broad arch-like manner and more or less follow the external side of the valve. Near the symphysal margin, ribs bend angularly back to the apex. The typical feature is the crenulated character of the symphysal facet.

Measurements. - The dimensions taken from the left valve are: $\mathrm{L}=14.0 \mathrm{~mm}$, Lat $=8.3 \mathrm{~mm}, \mathrm{Lat} / \mathrm{L}=0.59$.

Remarks. - Ribbing of the species T. symphysocostatus (Trauth) is similar to that of L. lorioli (Renz), but in the species described we can see a crenulated symphysal facet that cannot be found in $T$. lorioli.
Occurrence. - Renz \& Habicht (1985) found this species in the Valanginian (southern Switzerland).

In the Central Western Carpathians (Butkov) and Northern Calcareous Alps (Bajuvaricum); the stratigraphic range is from the Early Valanginian (ammonite Busnardoites campylotoxus Zone) to the Late Valanginian (boundary between the ammonite Neocomites peregrinus and the Criosarasinella furcillata Zones).

\section{Thorolamellaptychus bermudensis (Renz, 1979)}

Figure 10J

1968 L. seranonis var. longa Trauth; Jaksch, p. 113, figs $47,48$.

1977 Lamellaptychus sp. indet. 1. - Renz, p. 504, pl. 1, fig. 23.

1979b Lamellaptychus bermudensis n. sp. - Renz, p. 592, pl. 1, fig. 2.

1980 Lamellaptychus postbermudensis n. sp. - Renz, p. 904, pl. 1, figs 8a, b.

1983 Lamellaptychus postbermudensis Renz. - Renz, p. 640, pl. 1, fig. 11.

1985 Lamellaptychus bermudensis Renz. - Renz \& Habicht, p. 400, pl. 2, figs 21-24.

1996 Lamellaptychus bermudensis Renz. - Eliáš et al., pl. 5, fig. 6 .

1996 Lamellaptychus bermudensis Renz. - Vašíček, pl. 4, fig. 4 .

Holotype. - Determined in Renz (1979 b) as the specimen designated as Lamellaptychus bermudensis, illustrated in pl. 1, fig. 2.

Material. - Three valves; specimen SNM-Z24893 is the best preserved.

Figure 10. A - Mortilletilamellaptychus mendrisiensis undulocostatus Boorová, Lobitzer, Skupien \& Vašíček, $2000 ; \times 3$; spec. GBA 2009/007/1. Gutrathsberg Quarry of Leube Cement Co. Ltd. at Gartenau, Northern Calcareous Alps. Lower part of the Rossfeld Formation, Late Valanginian. - B - Mortilletilamellaptychus stellariformis (Renz, 1978); × 3; spec. Ge00011. Kurovice Quarry, uppermost level (horizon E). Tlumačov Formation, Early Valanginian (Calpionellites Zone, ?Calpionellites darderi Subzone). $\bullet$ C - Mortilletilamellaptychus bicurvatus (Renz \& Habicht, 1985); $\times 2 ;$ spec. SNM-Z24903. Butkov Quarry, $6^{\text {th }}$ level. Ladce Formation, Manín Unit, Late Valanginian. • D - Mortilletilamellaptychus beyrichodidayi (Trauth, 1938); $\times 2$; spec. SNM-Z24895. Outcrop in a nameless creek below Mráznica Hill, Central Western Carpathians. Mráznica Formation, Late Valanginian. •E - Thorolamellaptychus aplanatus retroflexus Trauth, 1938; × 3; spec. SNM-Z24892. Revišné Locality, Slovakian Klippen Belt. Mráznica Formation, Late Valanginian. • F - Thorolamellaptychus noricus (Winkler, 1868); × 1; spec. SNM-Z24896. Butkov Quarry, $12^{\text {th }}$ level, Manín Unit. Ladce Formation, lower part of Late Valanginian. $\bullet \mathrm{G}-$ Thorolamellaptychus noricus (Winkler, 1868); $\times 3$; spec. SNM-Z24897. Butkov Quarry, $12^{\text {th }}$ level, Manín Unit. Ladce Formation, uppermost part of Early Valanginian (ammonite Busnardoites campylotoxus Zone). $\bullet \mathrm{H}-$ Thorolamellaptychus lorioli (Renz, 1979); $\times 2$; spec. V95-8/3. Outcrop V95-8 on a forest path north of Geisshoerndl, south-east of municipality of Grossraming, Schneeberg Syncline, Northern Calcareous Alps. Schrambach Formation, Late Valanginian. - I - Thorolamellaptychus symphysocostatus (Trauth, 1938); $\times$ 3; spec. SNM-Z21166. The specimen with a broken-through valve arch. Butkov Quarry, $8^{\text {th }}$ level, Manín Unit. Ladce Formation, Early Valanginian (Busnardoites campylotoxus Zone). • J - Thorolamellaptychus bermudensis (Renz, 1979); × 3, spec. SNM-Z24893. Butkov Quarry, 12 ${ }^{\text {th }}$ level, Manín Unit. Ladce Formation, Early Valanginian (Busnardoites campylotoxus Zone). $\bullet$ K - Thorolamellaptychus trauthi (Renz \& Habicht, 1985); $\times 3$, spec. Ge00012. Kurovice Quarry, uppermost level (horizon D2). Tlumačov Formation, Early Valanginian (Calpionellites Zone, ?Calpionellites darderi Subzone). Scale is $10 \mathrm{~mm}$. 

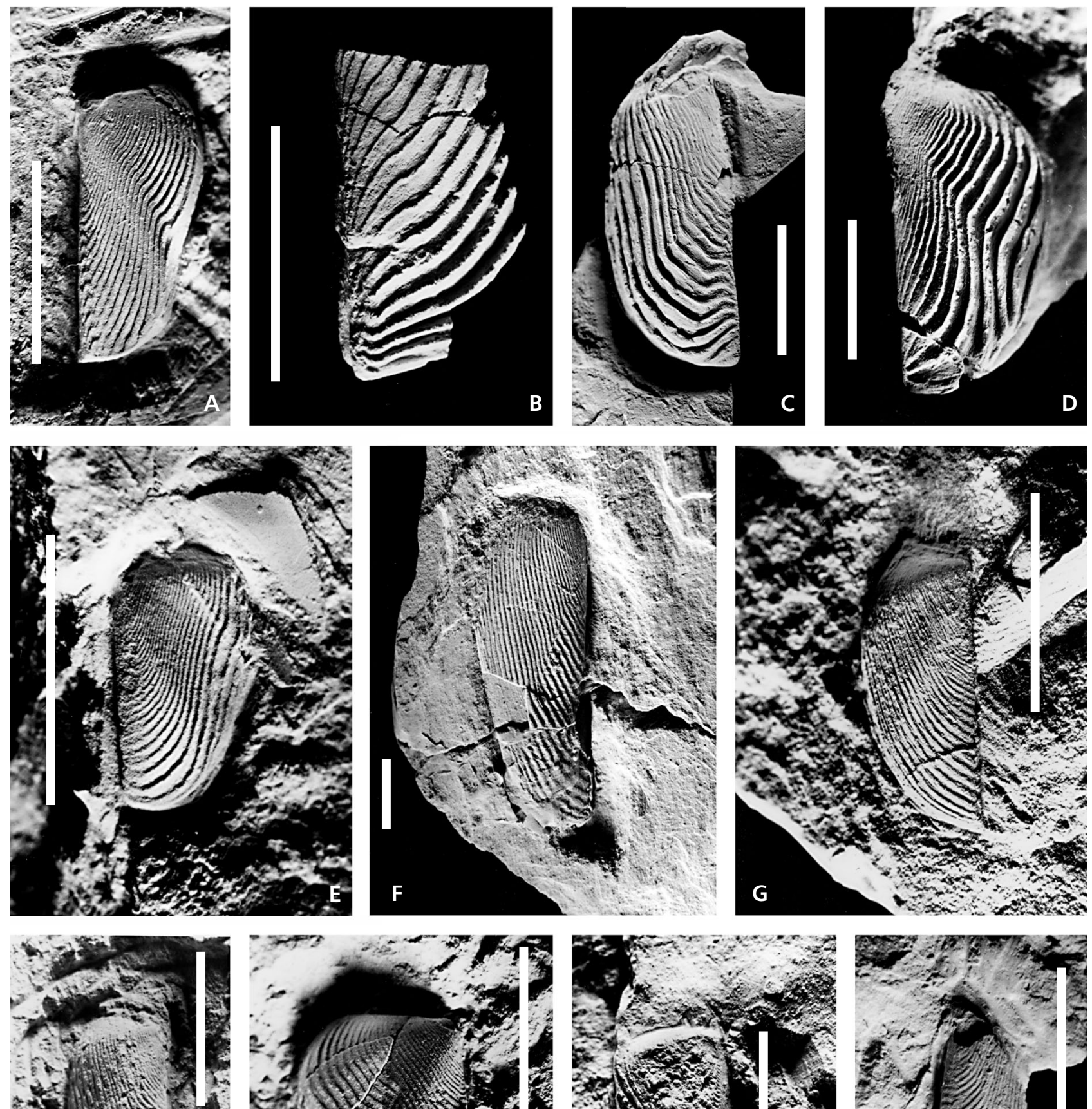

\& $\frac{1}{2}$ ill
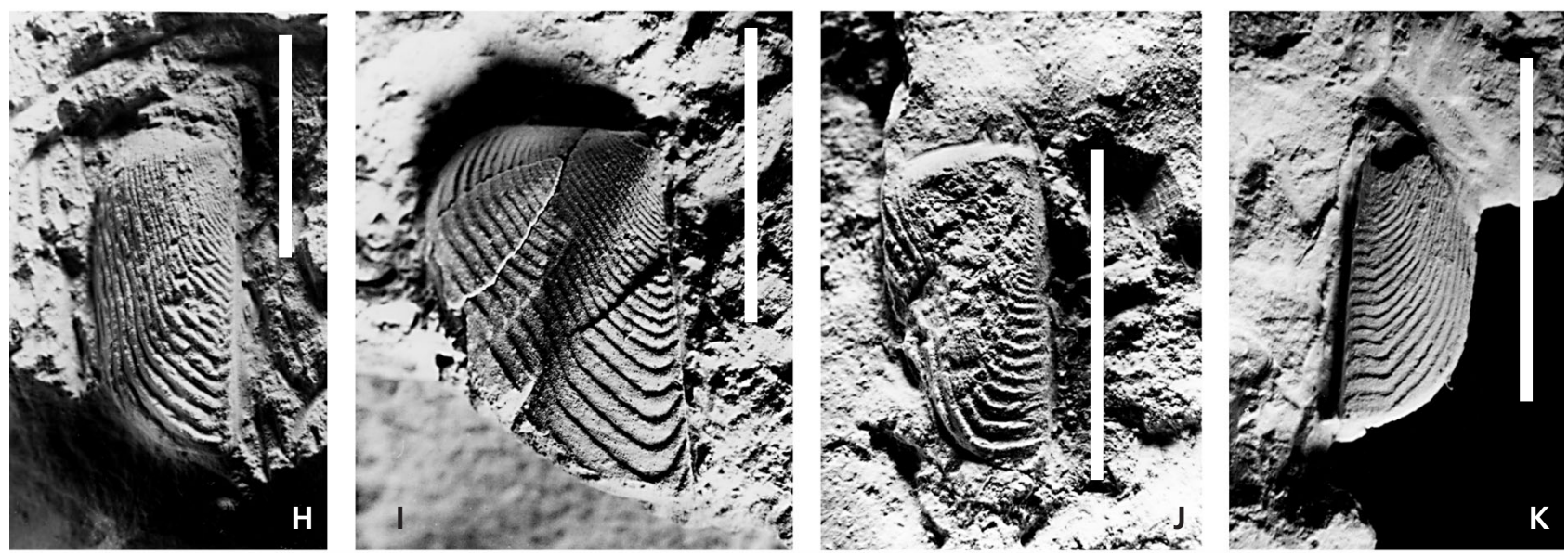
Description. - Usually small vaulted valves, with a keel and a lateral depression. Ribs are closely spaced and thin. In the area of the depression, the ribs are slightly inflected; in the area of the keel, they bend towards the symphysal margin. They converge on it at almost a right angle or greater.

Measurements. - The complete left valve has the following dimensions: $\mathrm{L}=9.0 \mathrm{~mm}$ and $\mathrm{Lat}=5.1 \mathrm{~mm}$, Lat $/ \mathrm{L}=0.57$.

Remarks. - Renz \& Habicht (1985) also included, without any detailed justification but rightfully, Lamellaptychus postbermudensis (defined by Renz 1980) in the synonymics of $T$. bermudensis.

Occurrence. - Renz's (1979b) holotype comes from Berriasian deposits. Renz \& Habicht (1985) reported distribution in the upper part of the Valanginian. According to Renz \& Habicht (1985), the species occurs throughout the Valanginian.

In the Outer Western Carpathians (Kurovice), Central Western Carpathians (Butkov) and Northern Calcareous Alps (Bajuvaricum), the stratigraphic range of the species is from the Late Berriasian (ammonite Subthurmannia boisseri Zone, along the boundary between the Tirnovella alpillensis and the Thurmanniceras otopeta Subzones) to the Early Valanginian (ammonite Busnardoites campylotoxus Zone).

\section{Thorolamellaptychus trauthi (Renz \& Habicht, 1985)} Figure 10K

1985 Lamellaptychus trauthi new form; Renz \& Habicht, p. 399, pl. 2, figs 12, 13.

1994 Lamellaptychus retroflexus Trauth. - Vašíček et al., p. 77 , pl. 24 , fig. 5 .

1995 Lamellaptychus trauthi Renz \& Habicht. - Michalík et al., p. 290, pl. 4, fig. 5.

1996 Lamellaptychus cf. retroflexus Trauth. - Eliáš et al., pl. 5 , fig. 5.

?1996 Lamellaptychus trauthi Renz \& Habicht. - Eliáš et al., pl. 5 , fig. 7 (= ?M. bicurvatus Renz \& Habicht).

1996 Lamellaptychus retroflexus Trauth. - Vašíček, pl. 4, fig. 6.

?1996 Lamellaptychus trauthi Renz \& Habicht. - Vašíček, pl. 4, fig. 7 [= ?M. bicurvatus (Renz \& Habicht)].

1996 Lamellaptychus trauthi Renz \& Habicht. - Vašíček \& Faupl, p. 113, pl. 4, fig. 8 .

?1998 Lamellaptychus trauthi Renz \& Habicht. - Vašíček \& Faupl, pl. 1, fig. 6 [= ?M. bicurvatus (Renz \& Habicht)].

?2000 Lamellaptychus trauthi Renz \& Habicht. - Boorová et al., pl. 14, fig. 9.
Holotype. - Lamellaptychus trauthi new form, determined by Renz \& Habicht (1985, pl. 2, fig. 12).

Material. - Six incomplete valves. Ge00012 is one of the best-preserved valves.

Description. - Narrow valves, mostly small, less frequently medium-sized, with a keel and a less conspicuous to conspicuous lateral depression. In the juvenile part of the valves, simple ribs are directed towards the symphysal margin at an angle of about $45^{\circ}$. Above the keel, adult ribs bend in a broad arch-like manner back towards the apex. Near the symphysal facet, they bend sigmoidally, more or less conspicuously. The end branch of the ribs leads towards the terminal edge. The last one or two ribs in the terminal area are incomplete. Some valves may have radial lines in the near-symphysal area.

Measurements. - The incomplete left juvenile valve Ge00012 has the following dimensions: $\mathrm{L}^{\prime}=7.6 \mathrm{~mm}$ and Lat' $=3.6 \mathrm{~mm}$.

Remarks. - The basic arrangement of adult ribs is similar to that of M. bicurvatus (Renz \& Habicht). The former species differs in the juvenile ribbing, which is of the "mortilleti" type.

Occurrence. - The species T. trauthi (Renz \& Habicht) occurs, according to Renz \& Habicht (1985), in the Late Berriasian and in the Early Valanginian of Switzerland. This species has also been reported from the Early Valanginian of the Central Western Carpathians in Slovakia (Vašíček 1996) and in the Late Valanginian of the Austrian Eastern Alps (Vašíček \& Faupl 1996).

In the Outer Western Carpathians (Kurovice) and Northern Calcareous Alps (Bajuvaricum), the stratigraphic range of the species is from the Early Valanginian (calpionellid Calpionellites Zone) to the Late Valanginian (ammonite Neocomites peregrinus Zone, Olcostephanus nicklesi Subzone).

\section{Genus Didayilamellaptychus Turculet, 1994}

Type species. - Aptychus Didayi Coquand, 1841.

Description. - Thick-walled, medium to large-sized valves with thin or strong ribs. Adult ribs bend back in a curved to angular manner or often occur in combination with both types of ribbing (Fig. 7H, I). The last few ribs can be incomplete.

Species composition. - Didayilamellaptychus didayi (Coquand, 1841), D. seranonis (Coquand, 1841), D. subsera- 
nonis (Renz, 1978), D. hennigi sp. nov., D. angulodidayi (Trauth, 1938), D. angulocostatus (Peters, 1854), D. angulicostatus (Pictet \& Loriol, 1858), D. atlanticus (Hennig, 1914), D. cristobalensis (O'Connell, 1921), D. andrusovi sp. nov., D. filicostatus (Stefanov, 1961), D. renzi sp. nov.

Occurrence. - Late Early Valanginian to the end of the Hauterivian.

\section{Didayilamellaptychus didayi (Coquand, 1841)} Figure 11A

1841 Aptychus Didayi (Nobis); Coquand, p. 389, pl. 9, fig. 10.

non 1849 Aptychus Didayi Coquand. - Quenstedt, p. 314, pl. 22, figs 21a, b (=Didayilamellaptychus angulodidayi Trauth).

1857 Trigonellites Didayi Giebel. - Ooster, p. 28, pl. 7, figs 16, ?8.

1858 Aptychus Didayi Coquand. - Pictet \& Loriol, p. 46, pl. 10, figs 1, 2.

?1867 Aptychus Didayi Coquand. - Pictet, p. 122, pl. 28, fig. 6.

?1868 Aptychus Didayi Coquand. - Winkler, p. 28, pl. 4, fig. 16.

?1868 Aptychus Gümbeli Winkler. - Winkler, p. 29, pl. 4, fig. 10.

1910 Aptychus Didayi Coq. - Kilian, pl. 3, fig. 10.

1921 Aptychus didayi Coquand. - O'Connel, fig. 5.

1938 Lamellaptychus didayi (Coquand). - Trauth, p. 198, pl. 14, figs 3, 4 .

1960 Lamellaptychus didayi Coquand. - Drushtchitz, p. 308, pl. 41, figs $6 \mathrm{a}-\mathrm{v}$.

1961 Lamellaptychus didayi (Coquand). - Stefanov, p. 216, pl. 2, figs 1-3, 5-10, non fig. 4 (=D. seranonis Coquand).

1962a Lamellaptychus didayi (Coquand). - Gąsiorowski, p. 258 , pl. 16 , fig. 8 .

?1962a Lamellaptychus seranonis (Coqu.). - Gąsiorowski, p. 258 , pl. 16 , fig. 3 .

1962b Lamellaptychus, group D, didayi Coquand. - Gąsiorowski, pl. 8, fig. 9 .

non 1968 Lamellaptychus didayi (Coquand). - Jaksch, p. 114, fig. 68 .

1974 Lamellaptychus didayi (Coquand). - Vašíček, p. 110, pl. 1, figs 2, 3 .

1976 Lamellaptychus didayi (Coquand). - Avram, p. 54, pl. 10, fig. 11.

?1977 Lamellaptychus didayi (Coquand). - Renz, p. 505, pl. 1 , fig. 26.

1978 Lamellaptychus didayi (Coquand). - Khalilov, p. 55, pl. 1, figs 12, ?11, ?13, ?14.

1985 Lamellaptychus didayi (Coquand). - Renz \& Habicht, p. 405, pl. 4, figs 5, 6 .
1985 Lamellaptychus seranonis (Coquand). - Renz \& Habicht, pl. 4, figs 19, 23, pl. 5, figs 2, 5, 6 .

1986 Lamellaptychus didayi (Coquand). - Calzada \& Santafé, p. 98, fig. 3 .

1988 Lamellaptychus didayi (Coquand). - Khalilov, p. 370 , pl. 19, figs $12, ? 11, ? 13, ? 14$.

1994 Lamellaptychus didayi (Coquand). - Vašíček et al., p. 74 , pl. 24, fig. 6 .

1995 Lamellaptychus (Didayilamellaptychus) didayi (Coquand). - Turculet \& Avram, p. 95, pl. 4, fig. 3.

1996 Lamellaptychus didayi (Coquand). - Jaksch, pl. 2, fig. 20.

1996 Lamellaptychus didayi (Coquand). - Vašíček, pl. 5, fig. 8 .

?1997 Lamellaptychus didayi (Coquand). - Vašíček \& Hoedemaeker, p. 35, pl. 2, fig. 2.

?2003 Tauriaptychus didayi (Coquand). - Kozlova \& Arkadiev, p. 42, pl. 7, fig. 16.

2009 Lamellaptychus didayi (Coquand). - Vašíček et al., p. 138 , fig. 4.3 .

Holotype. - On the basis of monotypy of Aptychus Didayi in Coquand (1841), illustrated by Coquand in pl. 9, fig. 10.

Material. - About 60 valves. The best-preserved valves include SNM-Z21168.

Description. - Medium to large valves with a prominent keel and a shallow lateral depression. Approximately in the area of the lateral depression, strong and widely spaced ribs begin to bend in a broad arch back towards the apex. The typical feature is the length-height ratio of the valve (Lat/L), the height of the valve (Lat) being greater. In the area of the lateral depression, the ribs show sigmoidal bending.

Measurements. - The very well preserved right valve SNM-Z21168 has the following dimensions: $\mathrm{L}=18.8 \mathrm{~mm}$ and $\mathrm{Lat}=12.2 \mathrm{~mm}$, Lat $/ \mathrm{L}=0.65$.

Remarks. - Ribbing of $D$. didayi is similar to that of D. seranonis (Coquand). The height of the $D$. didayi valve is much greater than that of the latter. Trauth (1938) reported a Lat/L ratio ranging from 0.40 to 0.58 for $D$. seranonis, and from 0.55 to 0.67 for $D$. didayi. To avoid the overlapping of values, we propose a limiting value of $\mathrm{Lat} / \mathrm{L}=0.55$, so that the lower limit value of $D$. didayi is 0.56 .

Occurrence. - Trauth (1938) reported a wide stratigraphic range (Tithonian), from the Berriasian to the Early Hauterivian. Renz \& Habicht (1985) reported distribution in the Valanginian, and Turculet \& Avram (1995) in the lowermost Hauterivian.

In the Klippen Zone of the Outer Western Carpathians (Podbranč, Horné Srnie), Central Western 
Carpathians (Strážovce, Zrázy, Košecká dolina, Podskalie, Lietavská Svinná, Butkov) and the Northern Calcareous Alps (Bajuvaricum); the stratigraphic range of the species is from the Early Valanginian (ammonite Busnardoites campylotoxus Zone) to the end of the Early Hauterivian.

\section{Didayilamellaptychus seranonis (Coquand, 1841)} Figure 11B

1841 Aptychus Seranonis (nobis); Coquand, p. 390, pl. 9, fig. 13.

?1841 Aptychus imbricatus. - Coquand, pl. 9, fig. 1.

1858 Aptychus Seranonis Coquand. - Pictet \& Loriol, p. 48, pl. 11, figs 1, 2, 7, ?4, non 3 (= L. herthae Winkler).

non 1867 Aptychus Seranonis Coquand. - Pictet, p. 123, pl. 28, figs 8-10 [fig. $9=$ M. bicurvatus (Renz \& Habicht)].

1921 Aptychus cubanensis n. sp. - O'Connel, p. 9, figs 9, 11-13.

1938 Lamellaptychus seranonis (Coquand) f. typ. - Trauth, p. 193, pl. 13, figs 27, 28, non fig. 29 [= M. bicurvatus (Renz \& Habicht)].

non 1942 Lamellaptychus seranonis (Coquand). - Imlay, p. 1460, pl. 11, figs 4, ?6 [= D. subseranonis (Renz)].

1961 Lamellaptychus angulocostatus (Peters) var. atlantica (Hennig). - Stefanov, p. 215, pl. 1, fig. 12.

1962a L. seranonis (Coqu.) f. typ. Trauth. - Gąsiorowski, p. 258 , tab. 16, fig. 4 , non fig. 3 (=?n. sp.).

1962b Lamellaptychus, group D (d $\alpha)$ seranonis (Coquand) f. typ. Trauth. - Gąsiorowski, tab. 8, figs 14, ?13.

1972 Lamellaptychus I. - Thompson, p. 35, fig. 2a

non 1972 Lamellaptychus seranonis (Coquand). - Renz, p. 615 , pl. 3 , fig. 4 [ =D. subseranonis $($ Renz); fig. $5=$ D. angulocostatus (Peters)].

1977 Lamellaptychus seranonis (Coquand). - Renz, p. 506, pl. 1, fig. 28, non figs 29, 30 (=D. subseranonis Renz).

?1978 Lamellaptychus seranonis (Coquand). - Renz, p. 905 , pl. 1, figs 13,15 .

1983 Lamellaptychus seranonis (Coquand). - Renz, pl. 1, fig. 6 .

1985 Lamellaptychus seranonis (Coquand). - Renz \& Habicht, p. 412, pl. 4, fig. 17, fig. ?19, non fig. 23 [=D. didayi (Coquand)], pl. 5, figs 3, 4, non figs 2,5 [= D. didayi (Coquand) $]$.

non 1992 Lamellaptychus seranonis (Coquand). - Vašíček et al., p. 51, pl. 9, fig. 5 (=D. subseranonis Renz).

non 1994 Lamellaptychus seranonis seranonis (Coquand). Vašíček et al., p. 74, pl. 24, fig. 7 (= D. subseranonis Renz).

non 1994 Lamellaptychus seranonis fractocostatus Trauth. Vašíček et al., p. 75, pl. 24, fig. 8 (= D. hennigi n. sp.).
?1995 Lamellaptychus (Didayilamellaptychus) seranonis (Coquand). - Turculet \& Avram, p. 94, pl. 3, fig. 11.

non 1996 Lamellaptychus seranonis fractocostatus Trauth. Vašíček, pl. 5, fig. 6 (=D. hennigi n. sp.).

1996 Lamellaptychus seranonis seranonis (Coquand). Vašíček, pl. 5, fig. 7.

non 1996 Lamellaptychus seranonis ssp. 1. - Vašíček, pl. 6, fig. 1 (=D. hennigi n. sp.).

Holotype. - On the basis of the monotypy of Aptychus Seranonis in Coquand (1841, pl. 9, fig. 13). The specimen is juvenile and imperfectly illustrated. The basic morphology of the species as indicated by Trauth (1938) is shown better by valves illustrated by Pictet \& Loriol (1858, pl. 11, figs 1,2$)$.

Material. - Sixteen specimens. The best representative of the species is the valve SNM-Z24894.

Description. - Medium to large-sized valves with a keel and a lateral depression. At maturity, the ribs are strong and wide apart. Approximately in the middle of the zone between the keel and the symphysal margin, or closer to the symphysal margin, the ribs bend back in a curved to subangular manner towards the apex. In the lateral depression, the ribs may be only slightly bent; they are often even sigmoidally bent.

Measurements. - A very well preserved left valve (SNM-Z24894) has the following dimensions: $\mathrm{L}=32.8 \mathrm{~mm}$, Lat $=16.7 \mathrm{~mm}$, Lat $/ \mathrm{L}=0.51$.

Remarks. - The character of the ribbing is variable in terms of the width of the adult ribs, in the position of the axis of their back bend in relation to the keel and the symphysal margin and the simple to strongly sigmoidal bend of the ribs in the lateral depression. $D$. seranonis resembles $D$. didayi somewhat in basic ribbing. However, there is a significant difference between them in terms of length-height parameters; $D$. seranonis belongs to the category of "slender" valves.

Occurrence. - Gąsiorowski (1962a) assigned D. seranonis (Coquand) to the interval from the Late Valanginian to the Early Hauterivian. Renz \& Habicht (1985) assigned their findings to the Hauterivian (Switzerland) and Turculet \& Avram (1995) to the Valanginian/Hauterivian boundary (Svinita, Rumania). Vašíček (1996) delimited the interval from the higher Late Valanginian to the end of the Early Hauterivian (most recent occurrences identical to $D$. $d i$ dayi). D. seranonis has been recovered from Early Cretaceous sediments from Antarctica (Thompson, 1972).

In the Outer Western Carpathians (Horné Srnie, Revišné), Central Western Carpathians (Strážovce, Zrázy, Košecká dolina, Lietavská Svinná, Butkov) and Northern 
Calcareous Alps (Bajuvaricum); the stratigraphic range of the species is from the late Early Valanginian (ammonite Busnardoites campylotoxus Zone) to the Early Hauterivian.

\section{Didayilamellaptychus subseranonis (Renz, 1978) Figure 11C}

1972 Lamellaptychus seranonis (Coquand); Renz, p. 615, pl. 3, fig. 4, non figs 5a, b $[=D$. angulocostatus (Peters)].

1974 Lamellaptychus cf. seranonis (Coquand). - Vašíček, p. 110 , pl. 1, fig. 5 .

1977 Lamellaptychus seranonis (Coquand). - Renz, p. 506, pl. 1, figs 29,30 .

1978 Lamellaptychus subseranonis n. sp. - Renz, p. 904, pl. 1, fig. 12.

1978 Lamellaptychus seranonis (Coquand). - Renz, p. 905, pl. 1, figs 13, 15.

?1983 Lamellaptychus subseranonis Renz. - Renz, p. 640, pl. 1 , fig. 9.

1985 Lamellaptychus subseranonis Renz. - Renz \& Habicht, p. 411, pl. 4, figs 12, 16, 18, 21, ?figs 13, 14, non figs 11, 15 [=?D. seranonis (Coquand)].

1992 Lamellaptychus seranonis (Coquand). - Vašíček et al., p. 51, pl. 9, fig. 5 .

1994 Lamellaptychus seranonis seranonis (Coquand). Vašíček et al., p. 74, pl. 24, fig. 7.

?1995 Lamellaptychus (Didayilamellaptychus) seranonis (Coquand). - Turculet \& Avram, p. 94, pl. 3, fig. 11.

?2000 Lamellaptychus seranonis (Coquand). - Vašǐček \& Faupl, pl. 2, fig. 6.

Holotype. - On the basis of the monotypy of Lamellaptychus subseranonis in Renz (1978, pl. 1, fig. 12). The holotype is a juvenile and very incomplete specimen. The morphology of the species is documented best by the description of the left valve of a specimen in Vašíček et al. (1994, pl. 24, fig. 7).

Material. - The best-preserved specimen (SNM-Z21169) is a pair of valves.

Description. - Medium to large valves with a keel but without a lateral depression or with only a shallow depression. Ribs, at the beginning relatively thin and closely spaced, gradually becoming larger and drawing apart from each other. The ribs are broadly bent. The bend begins in the vicinity of the keel. Near the symphysal margin, ribs bend indistinctly back towards the apex.

Measurements. - Measurements were made on the left, more complete valve that has a moderately deformed outer margin. Dimensions are as follows: $\mathrm{L}=22.3 \mathrm{~mm}$ and $\mathrm{Lat}=$ $9.0 \mathrm{~mm}, \mathrm{Lat} / \mathrm{L}=0.40$.

Remarks. - A striking feature is the obtuse round bend of ribs running from the flank of the valve back towards the apex.

Occurrence. - D. subseranonis occurs in the Late Valanginian to the Early Hauterivian. Type material comes from the Blake Bahama Basin. Furthermore it is described from the East and West Pacific and from the Manín Unit in the Western Carpathians. It probably also occurs in the Northern Calcareous Alps (Reichraming Nappe) and in Rumania.

A pair of valves from the Butkov Quarry (Manín Unit in the Central Western Carpathians) come from Late Valanginian strata.

\section{Didayilamellaptychus hennigi sp. nov.} Figure 11D

?1938 Lamellaptychus seranonis (Coqu.) var. n. fractocosta. - Trauth, p. 197.

1974 Lamellaptychus angulicostatus fractocostatus Trauth. - Vašíček, p. 109, pl. 1, fig. 1.

1978 Lamellaptychus seranonis fractocostatus Trauth. Renz, p. 506, pl. 1, fig. 14.

1985 Lamellaptychus seranonis (Coquand). - Renz \& Habicht, pl. 5, fig. 4.

1985 Lamellaptychus seranonis fractocostus Trauth. Renz \& Habicht, p. 413, pl. 4, figs 24, 25, ?20, pl. 5, fig. 1.

1994 Lamellaptychus seranonis fractocostatus Trauth. Vašiček et al., p. 75, pl. 24, fig. 8.

1996 Lamellaptychus seranonis fractocostatus Trauth. Vašíček, pl. 5, fig. 6.

1996 Lamellaptychus seranonis ssp. 1. - Vašíček, pl. 6, fig. 1.

Holotype. - Lamellaptychus seranonis fractocostatus Trauth, described and illustrated in Vašíček et al. (1994, pl. 24, fig. 8). It is kept in the collections of the Slovak National Museum in Bratislava under the depository number SNM-Z21170.

Derivatio nominis. - In honour of E. Hennig, who was concerned with the Early Cretaceous aptychi from the Cape Verde Islands at the beginning of the last century.

Type locality. - Butkov Quarry, $7^{\text {th }}$ level of the quarry.

Type horizon. - Manín Unit, Mráznica Formation, Early Hauterivian.

Material. - Six differently preserved valves. The holotype SNM-Z21170 is the best-preserved valve. 
Diagnosis. - Valves with strong ribs, with a keel and a lateral depression. Ribs bend sigmoidally in the lateral depression. After the backwards subangular to arch-like bend in the vicinity of the keel, the terminal branches of the ribs make an angle of $45^{\circ}$ with the symphysal margin.

Description. - Medium size valves with strong, subangularly backwards bending ribs. On the flanks of valves there are depressions in which the ribs are sigmoidally bent. Adult ribs (sometimes with the exception of the last rib which may be incomplete) end on the symphysal margin with which they make an angle of $45^{\circ}$.

Measurements. - The perfectly preserved left valve of SNM-Z21170 (holotype) has the following dimensions: $\mathrm{L}=25.8 \mathrm{~mm}$, Lat $=12.5 \mathrm{~mm}, \mathrm{Lat} / \mathrm{L}=0.48$.

Remarks. - The main difference between D. seranonis and $D$. hennigi is the distinct backward bend of the ribs making an angle of about $45^{\circ}$ with the symphysal margin. The ribs bend backwards in a continuous arch-like to subangular manner. In the case of $D$. hennigi, another significant feature is the lateral depression, in which at least part of the ribs are sigmoidally bent.

Occurrence. - Renz \& Habicht (1985) found this species in Hauterivian deposits.

In the Central Western Carpathians (Strážovce, Zrázy, Košecká dolina, Butkov), the stratigraphic range of this newly described species ranges from the Late Valanginian (ammonite Criosarasinella furcillata Zone) to the Early Hauterivian.

\section{Didayilamellaptychus angulodidayi (Trauth, 1938)} Figure 11E

1849 Aptychus Didayi Coquand; Quenstedt, p. 314, pl. 22, figs $21 \mathrm{a}, \mathrm{b}$.

1938 Lamellaptychus angulo-didayi n. n. f. typ. - Trauth, p. 212, pl. 14, figs 28, 29.

1968 Lamellaptychus angulo-didayi Trauth. - Jaksch, fig. 70.

non 1985 Lamellaptychus angulodidayi Trauth. - Renz \& Habicht, p. 410, pl. 4, fig. 7 (=M. beyrichodidayi Trauth).

Holotype. - Aptychus Didayi Coquand in Quenstedt (1849, pl. 22, figs 21a, b).

Material. - Eleven valves. SNM-Z24898 is one of the best-preserved valves.

Description. - Valves medium to large size with a prominent keel and a lateral depression. The inflection of the ribs is distinct in the area of the lateral depression. In the juvenile part of the valves, the ribs are angular to subangular, arch-shaped in the adult part, and end at the symphysal facet. A sigmoidal bend in the area of the lateral depression may be present in some valves.

Measurements. - The left valve of specimen SNM-Z24898 is incomplete. Its dimensions are as follows: $\mathrm{L}^{\prime}=18.8 \mathrm{~mm}$ and Lat' $=13.3 \mathrm{~mm}$.

Remarks. - The valve illustrated by Renz \& Habicht (1985, pl. 4, fig. 7) belongs to the species $M$. beyrichodidayi (Trauth) and not to $D$. angulodidayi (Trauth).

Occurrence. - The author of the species placed his findings in the Neocomian.

In the Outer Western Carpathians (Podbranč, Revišné) and the Central Western Carpathians (Strážovce, Zrázy, Košecká dolina, Butkov), the stratigraphic range of the species is from the Late Valanginian (ammonite Neocomites peregrinus Zone, Olcostephanus nicklesi Subzone) to the Early Hauterivian.

\section{Didayilamellaptychus angulocostatus (Peters, 1854)} Figure 11F

1854 Aptychus angulocostatus Peters; Peters, p. 441.

1857 Trigonellites Didayi Giebel. - Ooster, p. 28, pl. 7, figs $9,17, ? 14, ? 15$.

?1921 Aptychus pimientensis, new name. - O'Connell, p. 10, figs $15-18$.

1938 Lamellaptychus angulocostatus (Pet.) f. typ. Trauth, p. 204, pl. 14, fig. 13, non fig. 12 [=D. angulicostatus (Pictet \& Loriol)].

1938 Lamellaptychus angulocostatus (Pet.) var. n. atlantica-radiata. - Trauth, p. 211, pl. 14, figs 24, 25.

?1938 Lamellaptychus angulocostatus (Pet.) var. n. radiata. - Trauth, p. 207, pl. 14, fig. 14.

?1938 Lamellaptychus angulocostatus (Pet.) var. n. longa.Trauth, p. 209, pl. 14, fig. 18.

1942 Lamellaptychus angulocostatus (Peters). - Imlay, p. 1459 , pl. 11, figs 8, 9, ?10.

1961 Lamellaptychus angulocostatus (Peters). - Stefanov, p. 212, pl. 1, figs 1-4, non fig. 6 [= D. angulicostatus (Pictet \& Loriol)].

1962a L. angulocostatus (Pet.) f. typ. Trauth. - Gąsiorowski, p. 258, pl. 16, fig. 12.

1962b Lamellaptychus, group D (d $\gamma)$, angulocostatus (Peters) f. typ. Trauth. - Gąsiorowski, pl. 8, fig. 4.

1962b Lamellaptychus, group D (d $\gamma)$, angulocostatus (Peters) var. 1. - Gąsiorowski, pl. 8, fig. 3.

1965 Lamellaptychus angulocostatus Peters. - Fazzini, p. 13 , pl. 1, figs $1-3, ? 4-8$. 
1968 Lamellaptychus angulocostatus (Peters). - Jaksch, p. 118 , figs 85,91 .

1972 Lamellaptychus seranonis (Coquand). - Renz, pl. 3, figs $5 \mathrm{a}, \mathrm{b}$.

?1972 Lamellaptychus angulocostatus atlanticus radiatus Trauth. - Renz, pl. 3, fig. 3.

non 1972 Lamellaptychus angulocostatus (Peters). - Renz, pl. 4, fig. 1 [= D. angulicostatus (Pictet \& Loriol)].

1974 Lamellaptychus angulocostatus (Peters). - Houša, p. 31, pl. 2, figs $1-3$, pl. 3, figs $2-5$, pl. 4, figs $1,3,6$, pl. 5, figs $1,5,6$, pl. 6, figs $1,4-8,10$, pl. 7, figs $1-7$, pl. 8 , fig. 3 , pl. 9 , figs 7,8 .

1976 Lamellaptychus angulocostatus (Peters) forma radiata Trauth. - Avram, p. 59, pl. 10, fig. 13.

?1976 Lamellaptychus angulocostatus (Peters) f. typica Trauth. - Avram, p. 58, pl. 10, fig. 10.

1976 Lamellaptychus angulocostatus (Peters) forma radiata Trauth. - Patrulius \& Avram, p. 194, pl. 10, fig. 18.

?1977 Lamellaptychus angulocostatus (Peters). - Renz, pl. 1, figs 34, 35, pl. 2, figs 1, 2 .

1977 Lamellaptychus angulicostatus angulicostatus (Pictet \& Loriol). - Vašíček, p. 131, pl. 1, fig. 4.

?1978 Lamellaptychus angulocostatus (Peters). - Renz, p. 905, pl. 1, fig. 17.

?1983 Lamellaptychus angulocostatus (Peters). - Renz, pl. 1, figs 2, 5 .

1985 Lamellaptychus angulocostatus (Peters). - Renz \& Habicht, p. 413, pl. 5, figs 10, 15, non figs 9, 12 [= D. filicostatus (Stefanov)].

1985 Lamellaptychus angulocostatus cristobalensis O’Connel. - Renz \& Habicht, p. 414, pl. 5, figs 7, 11, ?13.

?1986 Lamellaptychus angulocostatus (Peters). - Calzada \& Santafé, p. 99, pl. 3.

1988 Lamellaptychus angulicostatus atlantica-radiata Trauth. - Khalilov, p. 371, pl. 13, fig. 10.

1992 Lamellaptychus angulocostatus (Peters). - Vašíček et al., p. 52, pl. 9, fig. 6 .

1994 Lamellaptychus angulocostatus (Pictet \& Loriol). Rabrenović \& Jankičević, pl. 2, fig. 7, ?fig. 5, non fig. 4 (=D. renzi $\mathrm{n}$. sp.), non fig. 6 (=D. cristobalensis O'Connell).

1995 Lamellaptychus (Didayilamellaptychus) angulocostatus angulocostatus (Peters). - Turculet \& Avram, p. 95, pl. 4, figs 5, 8, 10, ?6, ?7, ?9, ?12, ?13, pl. 5, figs $5, ? 1, ? 3, ? 8, ? 13$.

1995 Lamellaptychus (Didayilamellaptychus) angulocostatus longus (Peters). - Turculet \& Avram, pl. 5, fig. 7.

1995 Lamellaptychus angulocostatus angulocostatus (Peters). - Vašíček \& Michalík, p. 306, pl. 1, figs 1, 5.

1995 Lamellaptychus angulocostatus radiatus Trauth. Vašíček \& Michalík, p. 309, pl. 1, figs 7-9.
1996 Lamellaptychus angulocostatus angulocostatus (Peters). - Vašíček, pl. 6, fig. 7.

1996 Lamellaptychus angulocostatus radiatus Trauth. Vašíček, pl. 6, figs 5, 6.

1997 Lamellaptychus angulocostatus angulocostatus (Peters). - Vašíček \& Hoedemaeker, p. 36, pl. 2, fig. 3.

1997 Lamellaptychus angulocostatus radiatus Trauth. Vašíček \& Hoedemaeker, p. 37, pl. 2, fig. 4.

2000 Lamellaptychus angulocostatus angulocostatus (Peters). - Vašíček \& Faupl, pl. 5, fig. 9.

2009 Lamellaptychus angulocostatus (Peters). - Vašíček et al., p. 138, fig. 4.4 .

?2009 Lamellaptychus cf. angulocostatus (Peters). - Vašíček et al., fig. 4.5 .

Lectotype. - Peters (1854) provided a description of the genus without illustration. Trauth (1938) illustrated two different specimens under the name $L$. angulocostatus (Peters) in his broad conception of the genus; in the first one (pl. 14, fig. 12) he refigured the specimen of Pictet \& Loriol (1858) which belongs, according to our opinion, to $D$. angulicostatus. The other specimen (pl. 14, fig. 13) belongs to D. angulocostatus. Houša (1974) designated the most complete valve as the lectotype from several valves from Peters' original material which are deposited in the collections of the Austrian Geological Survey in Vienna. It is illustrated under the name Lamellaptychus angulocostatus (Peters) in Houša (1974), pl. 7, figs 1-4.

Material. - 27 incomplete valves. One of the most wellpreserved valves is specimen SNM-Z24899.

Description. - Medium to large-sized valves with a keel, but without a lateral depression. Ribs are angular in the area of the keel so that in the following area they run towards the apex. Adult ribs usually loose the angular bend. They become arch-shaped, which is also visible in the arch-shaped near-symphysal branch of the ribs. The last two to three ribs are incomplete. Ribs on the flanks of the valve usually run subparallel with the symphysal margin. Radial lines may occasionally occur between the keel and the symphysal margin.

Measurements. - The slightly incomplete left valve of specimen SNM-Z24899 (illustrated in Vašíček 1996, pl. 6, fig. 7) has the following dimensions: L'= $18.0 \mathrm{~mm}$ and Lat' $=7.1 \mathrm{~mm}$.

Remarks. - D. angulocostatus differs from D. angulicostatus (Pictet \& Loriol) in the absence of a lateral depression, ribbing on the flanks of the valves in which the ribs are subparallel with the symphysal margin, less tightness in the branches of angular ribs and a transition in adult ribs from angular to arch-shaped ribs. Radial lines may be present 
between the keel and the symphysal margin (see Vašíček 1996, pl. 6, figs 5, 6). These lines can be indistinct or even invisible if not suitably illuminated (Vašíček 1996, pl. 6, fig. 5); on the contrary, if suitably illuminated, they are clearly present (pl. 6, fig. 6). The radial lines are present e.g. on valves illustrated under the name $L$. angulocostatus (Peters) by Stefanov (1961, pl. 1, figs 1, 2). However, radial lines are not visible in the illustration by Stefanov. On the other hand, the same author (text-figs 1, 2, pl. 1, fig. 7 and fig. 10) illustrated valves of $L$. angulocostatus var. radiata Trauth, in which radial lines are clearly visible. Nevertheless, these specimens differ from the true $D$. angulocostatus in ribbing, because they belong to the rank of D. renzi $\mathrm{n}$. sp.

Occurrence. - According to Gąsiorowski (1962a), this species and other morphologically related forms occur, as reported by Gąsiorowski (1962a) for D. angulicostatus, in a wide stratigraphic range, namely from the Berriasian to the Barremian. Vašíček \& Michalík (1995) placed their findings in the Late Hauterivian (Western Carpathians); Vašíček (1996) confirmed the same age. Vašíček \& Hoedemaeker (1997) reported distribution in the Late Hauterivian (Río Argos, Spain), and Vašíček \& Faupl (2000) in the Austrian Alps.

In the Central Western Carpathians (Lietavská Lúčka, Butkov) and Northern Calcareous Alps (Bajuvaricum) the species is known only from Late Hauterivian deposits.

\section{Didayilamellaptychus angulicostatus (Pictet \& Loriol, 1858)}

Figure 11G, H

1858 Aptychus angulicostatus; Pictet \& Loriol, p. 46, pl. 10, figs $3,7, ? 6$, ?9-12, non figs 4,5 (=D. renzi $\mathrm{n}$. sp.).

1910 Aptychus angulicostatus Pict. \& de Lor. - Kilian, pl. 5, fig. 2 b, non $2 \mathrm{~b}$ (=D. cf. renzi n. sp.).

1938 Lamellaptychus angulocostatus (Peters) f. typ. Trauth, p. 204, pl. 14, fig. 12.

1961 Lamellaptychus angulocostatus (Peters). - Stefanov, p. 212, pl. 1, fig. 6 , non figs $1-4$ [= D. angulocostatus (Peters)].

1962a L. angulocostatus (Pet.) f. typ. Trauth. - Gąsiorowski, p. 258, pl. 16, fig. 13.

1962b Lamellaptychus, group D (d $\gamma)$, angulocostatus (Peters) f. typ. Trauth. - Gąsiorowski, pl. 8, fig. 1.

1968 Angulocostate Lamellaptychen. - Jaksch, p. 118, figs 83,84 .

1972 Lamellaptychus angulocostatus (Peters). - Renz, p. 616 , pl. 4, figs 1a, b.

1974 Lamellaptychus angulocostatus (Peters). - Houša, p. 31, pl. 2, fig. ?4, pl. 4, figs 8 , ?7, pl. 5, fig. 4, pl. 6, figs ?2, ?3, ?9, pl. 8, fig. 4, pl. 9, figs 6, 9 .

1977 Lamellaptychus angulicostatus angulicostatus (Pic- tet \& Loriol). - Vašíček, pl. 1, fig. 5, non fig. 4 (=D. angulocostatus Peters).

?1978 Lamellaptychus angulocostatus (Peters). - Renz, p. 905, pl. 1, fig. 17.

?1979a Lamellaptychus angulocostatus (Peters). - Renz, pl. 2, fig. 9.

1985 Lamellaptychus angulocostatus (Peters). - Renz \& Habicht, p. 413, pl. 5, fig. 15.

1994 Lamellaptychus angulocostatus (Peters). - Vašíček et al., pl. 24, fig. 13 .

1995 Lamellaptychus angulocostatus angulicostatus (Pictet \& Loriol). - Vašíček \& Michalík, p. 308, pl. 1, figs $2-4$.

1996 Lamellaptychus angulocostatus angulicostatus (Pictet \& Loriol). - Vašíček, pl. 6, fig. 8.

1997 Lamellaptychus angulocostatus angulicostatus (Pictet \& Loriol). - Vašíček \& Hoedemaeker, p. 37, pl. 2, fig. 5 .

Lectotype. - Aptychus angulicostatus in Pictet \& Loriol (1858, pl. 10, fig. 4).

Material. - Fifteen variably preserved valves. SNM-Z24900 and SNM-Z21175 are the best-preserved valves.

Description. - Medium to large-sized valves with a prominent keel and a lateral depression. Ribs on the outer area more or less follow the outline of the valve. In the region between the keel and the symphysal margin, ribs are angularly bent and run back towards the apex. Ribs in the vicinity of the symphysal margin approach the margin straight, without any indication of a bend, as can be seen in $D$. angulocostatus (Peters). The last few ribs in the terminal area are incomplete. In the area of the depression, ribs have inflections to sigmoidal bends.

Measurements. - The incomplete right valve of specimen SNM-Z24900 has the following dimensions: $\mathrm{L}=39.0 \mathrm{~mm}$, Lat $=12.5 \mathrm{~mm}$, Lat $/ \mathrm{L}=0.32$. Specimen SNM-Z21175: $\mathrm{L}^{\prime}=26.0 \mathrm{~mm}$.

Remarks. - Differences between the described subspecies and D. angulocostatus (Peters) are discussed in the remarks concerning D. angulocostatus (Peters).

Occurrence. - As with the previous species, Gąsiorowski (1962a) reported a broad stratigraphic range - from the Berriasian to the Barremian for D. angulicostatus. Vašíček \& Michalík (1995) and Vašíček (1996) assigned their findings to the Late Hauterivian of the Western Carpathians. Vašíček \& Hoedemaeker (1997) reported distribution in the Late Hauterivian (Río Argos, Spain) and Vašíček \& Faupl (1999) reported a similar distribution in the Austrian Alps. 
In the Western Carpathians (Podbranč, Strážovce, Nozdrovice, Lietavská Lúčka and Butkov), the stratigraphic range of the species is confined to the later Late Hauterivian.

\section{Didayilamellaptychus atlanticus (Hennig, 1914) sp. juv.} Figure 11I

1914 Aptychus atlanticus nov. sp.; Hennig, p. 155, pl. 2, figs $1 \mathrm{a}, \mathrm{b}$.

1938 Lamellaptychus angulocostatus (Pet.) var. atlantica (Henn.). - Trauth, p. 210, pl. 14, fig. 19 (refiguration of holotype).

1961 Lamellaptychus angulocostatus (Peters) var. atlantica (Hennig). - Stefanov, p. 215, pl. 1, fig. 8, non fig. 12 [= D. seranonis (Coquand)].

non 1962a Lamellaptychus angulocostatus (Pet.) var. atlantica (Henn.). - Gąsiorowski, fig. 16 (5).

non 1962a Lamellaptychus angulocostatus (Pet.) var. atlantica-radiata Trauth. - Gąsiorowski, fig. 16(11).

non 1962b Lamellaptychus, group D, angulocostatus (Pet.) var. atlantica (Henn.). - Gąsiorowski, pl. 8, fig. 11.

non 1972 Lamellaptychus angulocostatus atlanticus (Hennig). - Renz, p. 617, pl. 4, figs 2a, b, 3 (=D. renzi n. sp.).

1974 Lamellaptychus atlanticus (Hennig). - Houša, p. 43, pl. 8, fig. 2 (refiguration of the holotype).

non 1976 Lamellaptychus angulocostatus forma radiata Trauth. - Avram, p. 58, pl. 10, fig. 14.

?1977 Lamellaptychus angulicostatus ssp. ind. - Vašíček, p. 135 , pl. 1, fig. 6.

1983 Lamellaptychus angulocostatus atlanticus Trauth. Renz, pl. 1 fig. 3.

?1985 Lamellaptychus atlanticus (Hennig). - Renz \& Habicht, p. 415 , pl. 5, fig. 14 , non fig. 16 [= D. cristobalensis (O'Connell)].

1994 Lamellaptychus atlanticus (Hennig). - Vašíček et al., p. 75 , pl. 24, fig. 9 .

1996 Lamellaptychus atlanticus (Hennig). - Vašǐček, pl. 5, fig. 9.

2000 Lamellaptychus atlanticus (Hennig). - Vašíček \& Faupl, p. 614, pl. 2, fig. 7.

Holotype. - Aptychus atlanticus in Hennig (1914, pl. 2, figs 1a, b). Houša (1974, pl. 8, fig. 2) illustrated the holotype designated Lamellaptychus atlanticus at higher magnification.

Material. - Four valves; SNM-Z21171 is the best preserved.

Description. - Small valves with a keel and an indistinct lateral depression. Ribs are closely spaced and thin. Ribs bent back towards the apex in a broad arch that begins in the vicinity of the keel. The last few ribs are incomplete.
Measurements. - The well preserved but incomplete left valve of specimen SNM-Z21171 has the following dimensions: $\mathrm{L}^{\prime}=12.6 \mathrm{~mm}$ and Lat' $=5.4 \mathrm{~mm}$.

Remarks. - The holotype is an incomplete, relatively large valve (preserved length is $22 \mathrm{~mm}$ ). Ribbing is specific. In the incomplete juvenile part, ribs bend subangularly near the keel. The middle of the adult ribs runs almost perpendicularly to the symphysal margin; as they approach the margin, they bend towards the apex. Neither undulation nor crenulation is apparent on the ribs.

Later findings of $D$. atlanticus represent juvenile valves 10-12 mm long. Ribbing in these differs somewhat from adult ribs of the holotype; juvenile ribs are not, however, preserved on the holotype. Nevertheless, we assume that the juvenile ribbing of valves illustrated by Stefanov (1961) and later by Vašíček et al. (1994) would not differ from the type material. But the large valve assigned by Stefanov (1961, pl. 1, fig. 12) to D. atlanticus differs from this species by the size of the ribs and the completely different type of ribbing.

Occurrence. - The author of the species assigned it to the Neocomian; Renz \& Habicht (1985) assigned it to the Early Barremian(?) of Switzerland and the Blake-Bahama Basin; Vašíček et al. (1994) assigned it to the boundary between the Early and the Late Hauterivian of the Central Western Carpathians. Vašíček (1996) placed the valves described above in the higher part of the ammonite Subsaynella sayni Zone and the lower part of the Balearites balearis Zone (Western Carpathians).

On the basis of joint occurrence with the ammonite zone, the presence of $D$. atlanticus has been confirmed in the latest part of the Late Hauterivian (ammonite Plesiospitidiscus ligatus Zone) in the locality of Lietavská Lúčka (Central Western Carpathians).

\section{Didayilamellaptychus cristobalensis (O'Connell, 1921)} Figure 11J

1921 Aptychus cristobalensis, new species; O'Connell, p. 7, figs 7,8 .

1938 Lamellaptychus angulocostatus (Pet.) var. cristobalensis (O’Conn.). - Trauth, p. 211, pl. 14, fig. 26.

1942 Lamellaptychus angulocostatus (Peters) var. cristobalensis (O'Connell). - Imlay, p. 1460, pl. 11, figs 2,3 .

1959 Lamellaptychus angulocostatus (Pet.) var. cf. atlantica (Henn.). - Birkenmajer \& Gąsiorowski, p. 351, pl. 47 , fig. 5 .

1961 Lamellaptychus angulocostatus (Peters) var. cristobalensis (O’Connell). - Stefanov, p. 213, pl. 1, fig. 11 . 
1962a Lamellaptychus angulocostatus (Pet.) var. cristobalensis (O’Conn.). - Gąsiorowski, p. 258, Fig. 16, fig. 10.

1962b Lamellaptychus, group D (d $\gamma)$, angulocostatus (Pet.) var. cristobalensis (O’Conn.). - Gąsiorowski, pl. 8, fig. 8.

?1972 Lamellaptychus joides n. form. - Renz, p. 618, pl. 4, figs $6 a, b$.

non 1977 Lamellaptychus angulocostatus aff. cristobalensis (O'Connell). - Renz, p. 507, pl. 2, fig. 3 [= ?D. filicostatus (Stefanov)].

1985 Lamellaptychus angulocostatus cristobalensis (O’Connell). - Renz \& Habicht, p. 414, pl. 5, figs 7, 11,13 .

1985 Lamellaptychus atlanticus (Hennig). - Renz \& Habicht, p. 415 , pl. 5 , fig. 16 , non fig. 14 [= D. atlanticus (Hennig)].

1994 Lamellaptychus angulocostatus (Pictet \& Loriol). Rabrenović \& Jankičević, pl. 2, fig. 6.

1994 Lamellaptychus cristobalensis (O'Connell). - Vašíček et al., p. 75, pl. 24, fig. 12.

1995 Lamellaptychus cristobalensis (O’Connell). - Vašíček \& Michalík, pl. 1, fig. 6.

1996 Lamellaptychus cristobalensis (O'Connell). - Vašíček, pl. 6, fig. 2.

?2009 Lamellaptychus cf. cristobalensis (O'Connell). - Vašíček et al., p. 139, fig. 4.7.

Holotype. - Determined by O'Connell (1921) and designated Aptychus cristobalensis, illustrated in fig. 7.

Material. - Six valves; SNM-Z21174 is one of the best-preserved valves.

Description. - Thick-walled valves of medium to large size with a keel and a faint lateral depression. Ribs are rather thin. Juvenile ribs bend angularly in the area of the keel. Later, ribs become arch-shaped to rounded. Their arrangement between the keel and the symphysal margin is complicated by less distinct to striking crenulation. The last few ribs may be incomplete.

Measurements. - An almost complete left valve (SNM-Z21174) has the following dimensions: $\mathrm{L}=$ $26.0 \mathrm{~mm}$ and $\mathrm{Lat}=15.2 \mathrm{~mm}$, Lat $/ \mathrm{L}=0.58$.

Remarks. - The holotype is not well preserved. The characteristic zigzag crenulation is clearly visible especially on the valve illustrated by Stefanov (1961, pl. 1, fig. 11).

Occurrence. - According to data in the older literature, the stratigraphic position of the species is not clear (Early Hauterivian to Early Barremian).

The specimens from the Slovak Carpathians come from the later part of the Late Hauterivian deposits.

\section{Didayilamellaptychus andrusovi sp. nov. Figure 11K}

Holotype. - Valve SNM-Z24901, illustrated here in Fig. 11K.

Derivatio nominis. - In honour of the Slovak scientist D. Andrusov, who was one of the most outstanding Carpathian geologists of his time.

Type locality. - Butkov Quarry, $8^{\text {th }}$ level.

Type horizon. - Mráznica Formation, Early Hauterivian.

Material. - Three well preserved valves. SNM-Z24901 is the best preserved.

Figure 11. A - Didayilamellaptychus didayi (Coquand, 1841); $\times 2$; spec. SNM-Z21168. Butkov Quarry, $8^{\text {th }}$ level, Manín Unit. Mráznica Formation, Early Hauterivian. • B - Didayilamellaptychus seranonis (Coquand, 1841); $\times 1$; spec. SNM-Z24894. Butkov Quarry, $5^{\text {th }}$ level, Manín Unit. Mráznica Formation, Early Hauterivian. $\bullet$ C - Didayilamellaptychus subseranonis Renz, 1978; $\times 2$; spec. SNM-Z21169. Butkov Quarry, $12^{\text {th }}$ level. Ladce Formation, Late Valanginian. $\bullet$ D - Didayilamellaptychus hennigi sp. nov.; $\times 1$; spec. SNM-Z21170. Butkov Quarry, $7^{\text {th }}$ level. Mráznica Formation, Early Hauterivian. • E - Didayilamellaptychus angulodidayi (Trauth, 1938); ×2; spec. SNM-Z24898. Revišné Locality, Slovakian Klippen Belt. Mráznica Formation, Late Valanginian (ammonite Neocomites peregrinus Zone, Olcostephanus nicklesi Subzone). $\bullet$ F - Didayilamellaptychus angulocostatus (Peters, 1854); × 2; spec. SNM-Z24899. Laz Quarry near Lietavská Lúčka, Central Western Carpathians. Mráznica Formation, Late Hauterivian. - G - Didayilamellaptychus angulicostatus (Pictet \& Loriol, 1858); $\times 1$; spec. SNM-Z24900. Polomec Quarry near Lietavská Lúčka, $5^{\text {th }}$ level. Mráznica Formation, Late Hauterivian. • H - Didayilamellaptychus angulicostatus (Pictet \& Loriol, 1858); × 2; spec. SNM-Z21175. Polomec Quarry near Lietavská Lúčka $5^{\text {th }}$ level. Mráznica Formation, Late Hauterivian. •I - Didayilamellaptychus atlanticus (Hennig, 1914) sp. juv.; $\times 2$; spec. SNM-Z21171. Butkov Quarry, $8^{\text {th }}$ level. Mráznica Formation, boundary between Early and Late Hauterivian. - J - Didayilamellaptychus cristobalensis (O’Connell, 1921); × 1.5; spec. SNM-Z21174. Polomec Quarry near Lietavská Lúčka, debris on $4^{\text {th }}$ level. Mráznica Formation, Late Hauterivian. $•$ K - Didayilamellaptychus andrusovi sp. nov.; × 3; spec. SNM-Z24901. Butkov Quarry, $8^{\text {th }}$ level, 470 m. Mráznica Formation, Early Hauterivian. $\bullet$ L - Didayilamellaptychus filicostatus (Stefanov, 1961); $\times 1$; spec. SNM-Z24902. Polomec Quarry near Lietavská Lúčka, debris on $5^{\text {th }}$ level. Mráznica Formation, Late Hauterivian. $・ M-$ Didayilamellaptychus renzi sp. nov.; $\times 2$; spec. SNM-Z21172. Outcrop in municipality of Lietavská Svinná. Mráznica Formation, Late Hauterivian. • N - Didayilamellaptychus renzi sp. nov.; × 1; spec. SNM-Z21173. Butkov Quarry, $1^{\text {st }}$ level. Kališčo Formation, Late Hauterivian. Photos by K. Mezihoráková, Ostrava. The specimens were whitened with ammonium chloride prior to photographing. Scale is $10 \mathrm{~mm}$. 
Lucie Měchová et al. • Early Cretaceous ribbed aptychi
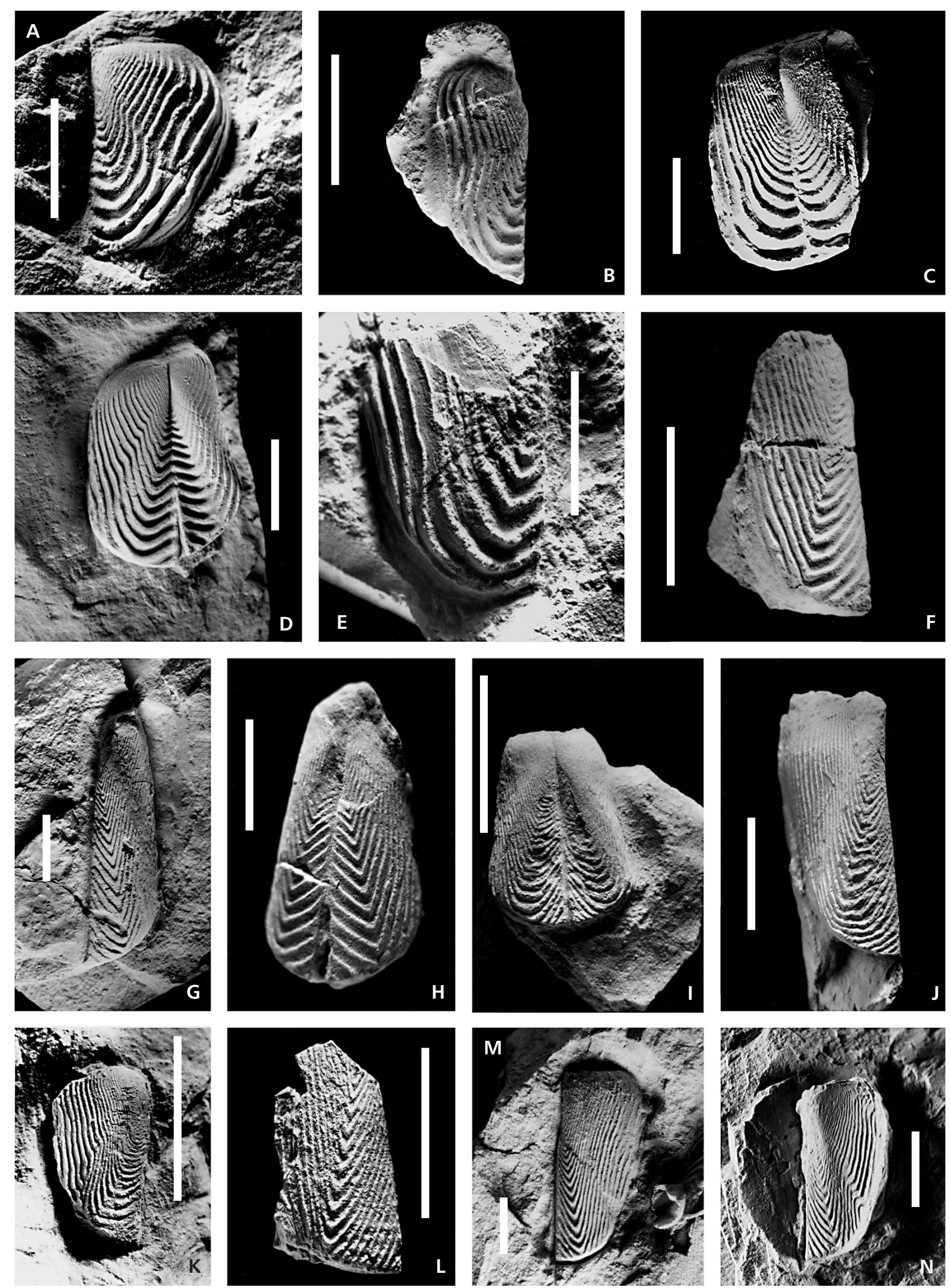
Diagnosis. - Wide valves with thin, closely spaced subangular ribs. There is an unconformable transition between the ribs of the outer and the terminal lateral area.

Description. - Wide, slightly vaulted valves, small in size, with fine, closely spaced ribs and with an indistinct keel and a shallow lateral depression. In the depression, the ribs are slightly inflected. Between the keel and the symphysal margin, the ribs bend back in a sharply curved manner towards the apical part of the valve. On transition between the lateral and the outer side of the valve, a discordance of the ribs is developed.

Measurements. - An incomplete left valve (holotype) has the following dimensions: $\mathrm{L}^{\prime}=11.3 \mathrm{~mm}$ and Lat' $=6.5 \mathrm{~mm}$.

Remarks. - No equivalent to the valves from Butkov were found in the literature, this led to the definition of a new taxon. In terms of the width of the valve, the described species is similar to the group of $D$. didayi (Coquand), but owing to the style of juvenile ribbing it is more like $D$. filicostatus (Stefanov). So far, discordance of ribs has been observed only in the case of valves of Berriasian to Valanginian age.

Occurrence. - So far the species has only been reported from Early Hauterivian deposits in the Butkov Quarry.

\section{Didayilamellaptychus filicostatus (Stefanov, 1961)} Figure 11L

1961 Lamellaptychus angulocostatus (Peters) var. filicosta n. var.; Stefanov, p. 214, pl. 1, fig. 9.

?1977 Lamellaptychus angulocostatus aff. cristobalensis (O’Connell). - Renz, p. 507, pl. 2, fig. 3.

non 1994 Lamellaptychus filicostatus filicostatus Stefanov. Vašíček et al., p. 76, pl. 24, fig. 10 (=D. renzi n. sp.).

1995 Lamellaptychus filicostatus filicostatus Stefanov. Vašíček \& Michalík, pl. 1, fig. 11.

1996 Lamellaptychus filicostatus Stefanov. - Vašíček, pl. 6, fig. 3, non fig. 4 (=D. renzi $\mathrm{n}$. sp.).

1997 Lamellaptychus cf. filicostatus Stefanov. - Vašíček \& Hoedemaeker, p. 39, pl. 2, fig. 9.

non 1997 Lamellaptychus filicostatus filicostatus Stefanov. Vašíček \& Hoedemaeker, p. 38, pl. 2, fig. 8 (=D. renzi n. sp.).

2009 Lamellaptychus cf. filicostatus Stefanov. - Vašíček et al., p. 138, fig. 4.6 .

Holotype. - D. filicostatus was defined, in accordance with the nomenclatorial rules, as an individual species as late as 1994 (Vašíček et al. 1994) under the authorship of Stefanov, on the basis of a specimen belonging to Stefanov
(1961, pl. 1, fig. 9), who designated it as Lamellaptychus angulocostatus (Peters) var. filicosta $\mathrm{n}$. var.

Material. - A single incomplete left valve (SNM-Z24902).

Description. - Medium size valves with an indistinct keel and without a lateral depression. The keel makes an angle with the symphysal area that ranges from about 15 to $20^{\circ}$. Closely spaced and relatively thin ribs on the flanks of the valves run subparallel with the symphysal margin. In the area of the keel, juvenile ribs are angularly bent and both the branches make an acute angle. The angle between branches is almost symmetric; initially it is acute in the adult area and gradually becomes markedly asymmetric. Whereas on adult valves, but the branches on the valve flanks remain straight, the branches closer to the symphysal area are more rounded. The last few ribs are not angular but rounded. The rib branch closest to the symphysal area makes an acute angle of about $30^{\circ}$ with the symphysal margin. As a consequence, the last three to five ribs are incomplete.

Measurements. - If the holotype was perfectly preserved, it would have a length of about $25 \mathrm{~mm}$. The incomplete specimen SNM-Z24902 has the following dimensions: $\mathrm{L}^{\prime}=25.9 \mathrm{~mm}$ and Lat' $=13.9 \mathrm{~mm}$.

Remarks. - One of the characteristic features of this species with thin, closely spaced ribs is the asymmetric form of the initially angular and later rounded ribs at maturity. Differences from the similar D. renzi are mentioned in remarks on the following new species.

Occurrence. - Stefanov (1961) assigned the Bulgarian holotype to the Early Hauterivian. Spanish and Carpathian specimens come from the Late Hauterivian.

A single Carpathian valve from Lietavská Lúčka, from the Polomec Quarry, more specifically is from deposits of Late Hauterivian age.

\section{Didayilamellaptychus renzi sp. nov.} Figure 11M, N

?1858 Aptychus angulicostatus. - Pictet \& Loriol, pl. 10, figs 4,5 .

?1910 Aptychus angulicostatus Pict. \& de Lor. - Kilian, pl. 5, fig. 2a.

1942 Lamellaptychus angulocostatus var. cristobalensis (O’Connell). - Imlay, pl. 11, fig. 2.

1961 Lamellaptychus angulocostatus var. radiata Trauth. -Stefanov, p. 213, pl. 1, fig. 7, ?fig. 10, ?text-figs 1, 2.

1972 Lamellaptychus angulocostatus atlanticus (Hennig). - Renz, p. 617, pl. 4, figs 2a, b, 3, ?4. 
?1974 Lamellaptychus angulocostatus (Peters). - Houša, pl. 2 , fig. 5.

1979a Lamellaptychus angulocostatus (Peters). - Renz, pl. 2 , fig. 9.

1979a Lamellaptychus angulocostatus cristobalensis (O’Connell). - Renz, pl. 2, fig. 3.

1985 Lamellaptychus angulocostatus (Peters). - Renz \& Habicht, pl. 5, fig. 9, ?12.

1994 Lamellaptychus filicostatus fractocostatus n. ssp. Vašíček et al., p. 76, pl. 24, fig. 11.

1994 Lamellaptychus filicostatus filicostatus Stefanov. Vašíček et al., pl. 24, fig. 10.

?1994 Lamellaptychus angulocostatus (Pictet \& Loriol). Rabrenović \& Jankičević, pl. 2, fig. 4.

1995 Lamellaptychus filicostatus fractocostatus Vašíček, Michalík \& Reháková. - Vašíček \& Michalík, pl. 1, fig. 10.

1996 Lamellaptychus filicostatus Stefanov. - Vašíček, pl. 6, fig. 4, non fig. 3 (=D. filicostatus).

1997 Lamellaptychus filicostatus filicostatus Stefanov. Vašíček \& Hoedemaeker, p. 38, pl. 2, fig. 8.

Holotype. - Valve illustrated under the name Lamellaptychus angulocostatus atlanticus (Hennig) by Renz (1972) in pl. 4 , fig. 3.

Derivatio nominis. - In honour of Dr. Otto Renz, former member of staff at the Museum of Natural History, Basel, who contributed significantly to detailed understanding of Late Jurassic and Early Cretaceous aptychi.

Type locality. - Western North Atlantic (Site 105, Leg 11, DSDP, core No. 18, 5 688,29 m).

Type horizon. - Hauterivian.

Material. - Four partly incomplete valves from the Carpathian area. The valves SNM-Z21172 and SNM-Z22173 are the best preserved.

Diagnosis. - Valves small to medium in size, with a keel. Closely spaced ribs angularly bend in the vicinity of the symphysal margin. The branches of angularly bent ribs make an acute angle. The last few ribs are rounded instead of angular.

Description. - Valves medium in size, with a prominent keel and usually a shallow lateral depression. Ribs are thin and closely spaced. They bend angularly to make an angle of about $10^{\circ}$ with the symphysal margin. Between the symphysal margin and the axis of the bent ribs, radial lines may occur. The branches of angular ribs make an acute angle of about $35^{\circ}$ with the margin. The last few ribs usually lose the angular character. On the flanks of the valves, the ribs are simply straight or slightly bent; cases of sigmoidal bends in the lateral depression are also known.

Measurements. - The very well-preserved right valve of specimen SNM-Z21172 has the following dimensions: $\mathrm{L}=15.0 \mathrm{~mm}$, Lat $=6.2 \mathrm{~mm}$, Lat $/ \mathrm{L}=0.41$. Specimen SNM-Z21173: $\mathrm{L}=23.3 \mathrm{~mm}$, Lat $=11.0 \mathrm{~mm}$, Lat $/ \mathrm{L}=0.47$.

Remarks. - The newly determined species is characterized mainly by the fact that the axis of rib angularity occurs very close to the symphysal margin, unlike in D. filicostatus. The angle between the ribs remains acute almost for the whole period of growth. The zone between the axis of rib angularity and the symphysal margin is simple or may be complicated by radial lines. These sometimes lead to negligible disturbance to the continuous ribbing.

Valves in the collection of Stefanov (1961) are remarkable for the well-developed radial lines. The zone of the radial lines is, however, always heavily corroded. In addition, one of the valves belonging to Stefanov (1961, fig. 2) is characterized by the fact that its ribs are, in contrast to the other valves in his collection, more complicated. Pictet \& Loriol's valves (1858, pl. 10, figs 4, 5) differ from the type material by having a distinct lateral depression.

Occurrence. - Renz (1972) did not classify his specimens stratigraphically. According to the overall composition of aptychi, the higher part of the Early or the Late Hauterivian is a possibility. Stefanov (1961) placed the Bulgarian specimens in the Early Hauterivian. D. renzi occurs across a relatively vast area. It is known from the Caribbean and the Atlantic, Bulgaria, the Western Carpathians, Switzerland and Spain.

Carpathian specimens are only of Late Hauterivian in age (ammonite Subsaynella sayni to Balearites balearis Zones).

\section{Conclusions}

We have proposed a new systematic classification for Early Cretaceous ribbed aptychi. Aptychi that do not represent any natural group of fossils are categorised in systematic units based on the classification and the nomenclatorial principles of the natural system of animals.

This proposal, which leads to the creation of a new hierarchy and new principles of aptychi classification, was preceded by a detailed analysis of the existing situation. In the course of the analysis it became clear that the principles of aptychi classification used hitherto were limited and consequently made the determination of other new taxa, especially in the category of subspecies, impossible. This circumstance was largely a result of the introduction and use of some subspecies names connected with morphological features visible on the valves of some aptychi, which 
Bulletin of Geosciences • Vol. 85, 2, 2010

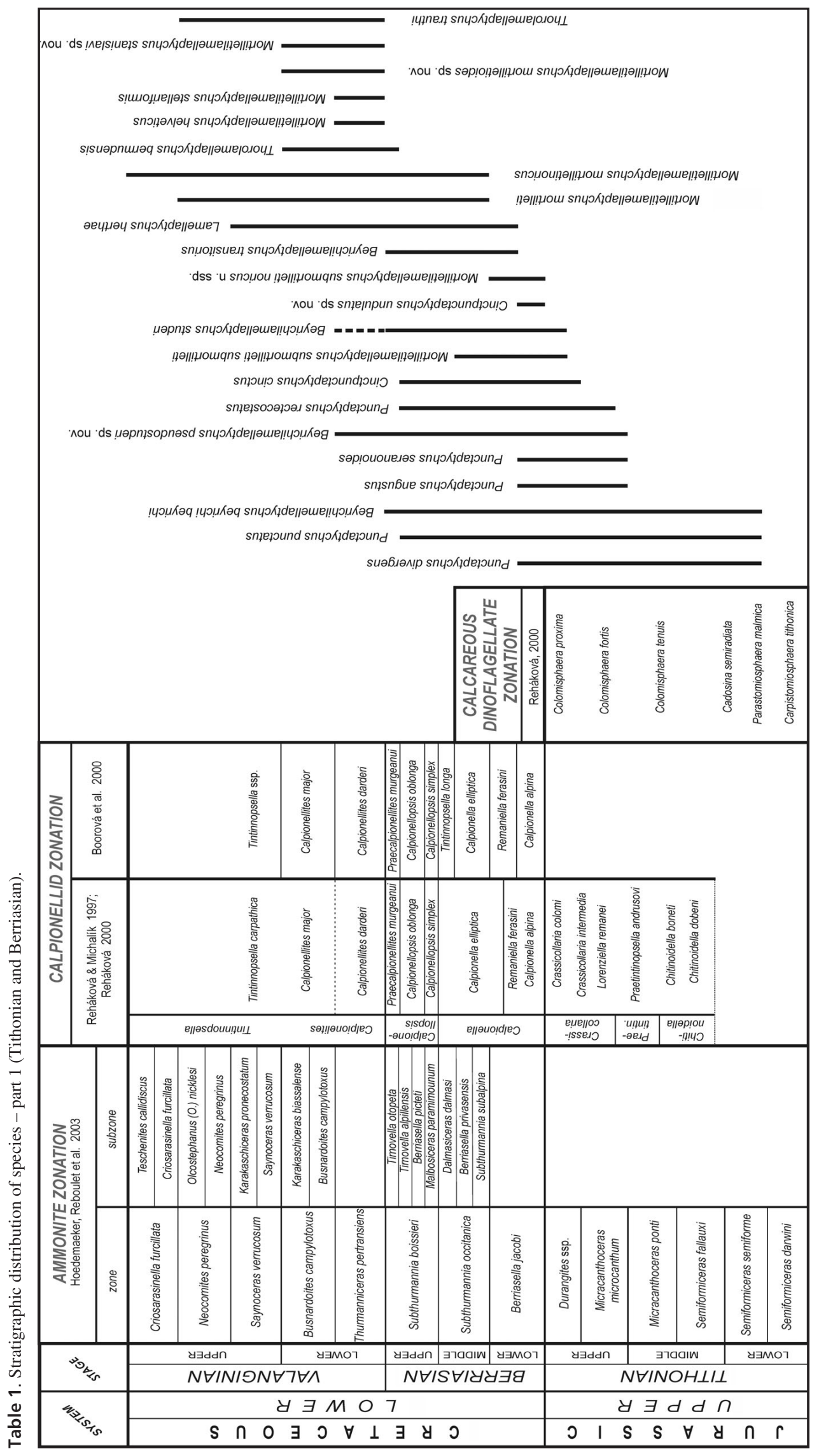




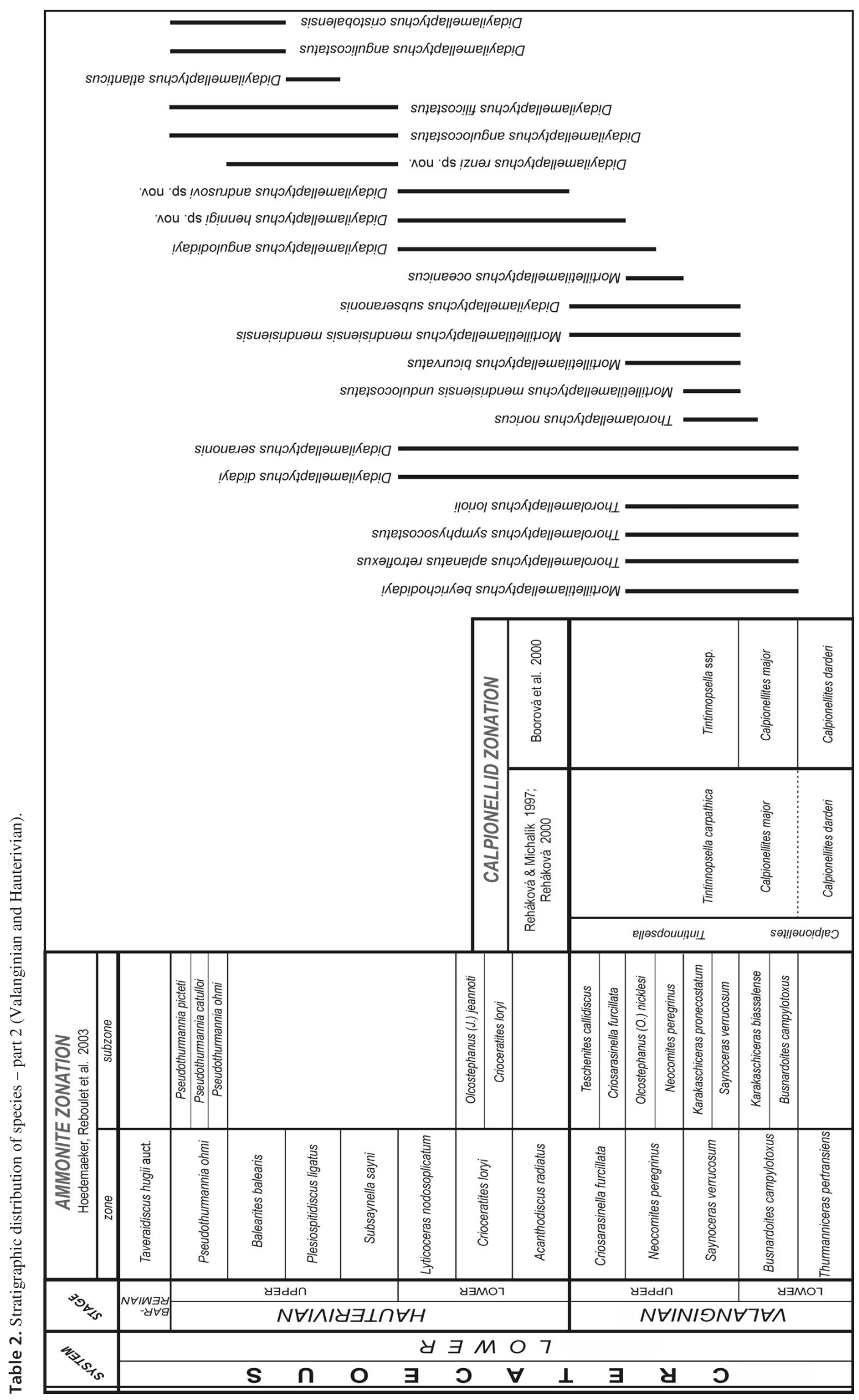


seemed to be, according to our study, of no true taxonomic importance. This is the case for subspecies names introduced by Trauth, namely "fractocostatus" and "radiatus". Reasons that led us to reject the use of the given names in taxonomy are explained in chapter 2.3. Thus correct adherence to the trinomial nomenclature of subspecies is once again possible.

According to our proposal for the classification and systematic units of Early Cretaceous aptychi two new family-level taxa have been determined: Punctaptychidae and Lamellaptychidae. In the family Punctaptychidae we have distinguished two genera, namely the Punctaptychus Trauth (an invalid synonym is Beyrichilamellaptychus Turculet, 1994) and the Cinctpunctaptychus gen. nov. The family Lamellaptychidae includes five genera: Lamellaptychus Trauth (invalid synonym is Lamellosuslamellaptychus Turculet, 1994) and Beyrichilamellaptychus Turculet, 1994, Thorolamellaptychus Turculet, 1994, Mortilletilamellaptychus gen. nov. and Didayilamellaptychus Turculet, 1994. The genera are divided into species and, when necessary, subspecies.

A special feature in the ribbing of Early Cretaceous aptychi is the occurrence of subangular to angular ribs which bend back towards the apex. The stratigraphically oldest occurrences of such ribs are known in the case of Punctaptychus. At the end of development of the given genus, the aforementioned phenomenon appears in adult ribs of a single species, namely P. seranonoides (Late Tithonian-Berriasian). Angularly to subangularly bent ribs are confined to the area in close proximity to the symphysal margin.

In the family Lamellaptychidae, the aforementioned phenomenon occurs sporadically in several representatives of the genera Mortilletilamellaptychus and Thorolamellaptychus, whereas in Didayilamellaptychus this feature represents a basic generic characteristic.

The angular bending of ribs in close proximity to the symphysal margin occurs in juvenile valves of Thorolamellaptychus aplanatus retroflexus (?Tithonian to Early Valanginian). However, this phenomenon disappears with valve growth, the ribs become gradually subangularly bent and the axis of bending moves gradually away from the symphysal margin. In the adult stage, the ribs bend back in an arch-like manner only. Similar ribbing can also be observed in Th. lorioli (Late Berriasian to Early Valanginian). The axis of angular and subangular bending of the ribs however remains, in the vicinity of the symphysal margin. A similar feature is also characteristic of Thorolamellaptychus symphysocostatus (late Early to Late Valanginian). Its symphysal facet is crenulated. Also in M. stanislavi (Early Valanginian), the angular bending of adult ribs is confined to the area in close proximity to the symphysal margin. Juvenile ribbing is different from that of the above-mentioned representatives of Thorolamellaptychus.
Backwards bent ribs, angular ribs, or combination of both in a more conspicuous form are characteristic of all the species of Didayilamellaptychus.

In accordance with the proposed systematics, we undertook an extensive revision of our own paleontological material from many Czech and Slovak localities in the Western (Outer and Central) Carpathians and also from the Northern Calcareous Alps (Austria). Although our contribution focuses on ribbed aptychi from the lower part of the Early Cretaceous, aptychi occurring in the uppermost Jurassic were also included in the study. One of the results of this extensive revision of aptychi is the description of 43 species and also subspecies, of which eight species and one subspecies are new: Cinctpunctaptychus undulatus, Beyrichilamellaptychus pseudostuderi, Mortilletilamellaptychus mortilletioides, M. submortilleti noricus, M. stanislavi, Didayilamellaptychus hennigi, D. andrusovi and D. renzi. The stratigraphical range of these species in comparison with the other species is shown in Tables 1 and 2.

With reference to the considerable frequency of occurrence, usually favourable preservation, distinct morphological variability in ribbing over short time periods, and easy determinability of valves, aptychi seem to be very suitable fossils for dating deposits from the lower part of the Early Cretaceous, although the capacity of these calcite valves for distinguishing stratigraphy is not as perfect as that of $e . g$. ammonites. However, they are also preserved in deep-water deposits where other fossils of stratigraphical importance have not been preserved.

\section{Acknowledgements}

The authors thank the management of the Institute of Geonics of the Academy of Sciences of the Czech Republic for moral and financial support leading to the realization of this contribution. In addition, the authors are obliged to K. Mezihoráková (Ostrava) for taking high quality photographs, R. Jelínková (Ostrava) for translation of the manuscript into English and the collective of Scientific Proofreading Services (Oxford) for linguistic corrections. The authors are very grateful to the journal referees, M. Košták (Charles University Prague) and J. Michalík (Geological Institute of the Slovak Academy of Sciences, Bratislava), for their constructive comments and remarks, which greatly improved this paper.

\section{Note}

Only in the course of printing, we were successful in obtaining a publication by Turculet, I. 2000. Aptihii din România. 178 pp. Editor Academiei Române, Bucuresti. This is a contribution of monographic character written prevailingly in Rumanian (only new species are also described in French). Turculet here summarises his lifelong knowledge of Upper Jurassic and Lower Cretaceous aptychi occurring in Rumania in accordance with his previous results. In the taxonomy part, Turculet uses his own 
classification based on subgenera (Turculet 1994) for calcareous aptychi; species nomenclature is based on Trauth (1938). For time and publication reasons, we could not take into account the above-mentioned publication in our contribution.

\section{References}

ARKELL, W.J. 1957. Aptychi, L437-L440. In MoORE, R.C. (ed.) Treatise on invertebrate paleontology, Part L, Cephalopoda, Mollusca 4. Geological Society of America \& University of Kansas Press, New York.

AVRAM, E. 1976. Les fossiles du flysch éocrétacé et des calcaires tithoniques des hautes vallées de la Doftana et du Tîrlung (Carpates orientales). Mémoires, Institut de Géologie et de Géophysique 24, 1-89.

BACHMAYER, F. 1963. Beiträge zur Palaeontologie oberjurassischer Riffe. I. Die Aptychen (Ammonoidea) des Oberjura von Stramberg (ČSR). Annalen des Naturhistorischen $M u$ seums Wien 66, 125-138.

BIRKENMAJER, K. \& GĄSIOROWSKI, S.M. 1959. Aptychy tytońskie i neokomskie na wtórnym złożu w senonie pasa skałkowego Polski. Rocznik Polskiego towarzystwa geologicznego 28(3), 345-358.

BLASCHKE, F. 1911. Zur Tithonfauna von Stramberg in Mähren. Annalen des Naturhistorischen Hofmuseums Wien 25(1-2), 143-222.

BoOROVÁ, D., LOBITZER, H., SKUPIEN, P. \& VAŠÍČEK, Z. 2000. Biostratigraphy and facies of Upper Jurassic-Lower Cretaceous pelagic carbonate sediments (Oberalm-, Schrambachand Roßfeld-Formation) in the Northern Calcareous Alps, South of Salzburg. Abhandlungen der Geologischen Bundesanstalt 56(1999), 273-318.

CalzadA, S. \& SANTAFé, J.V. 1986. Dos lamellaptychi crétacicos de Fortuna (Murcia). Mediterránea, Seria Geología 5, 97-104.

CoQuand, M. 1841. Mémoire sur les Aptychus. Bulletin de la Société géologique de France 12, 376-391.

CuZZI, G. 1958. La fauna ad <Aptycus> del giura superiore (malm) di ca' del Cherio (Val Cavallina). Atti della Società italiana di Scienze naturali di Milano 97, 251-283.

CUZZI, G. 1962. Osservazioni sul genere Punctaptychus e sulla specie Punctaptychus punctatus (Voltz) f. typ. Bolletino della Società paleontologica Italiana 1, 43-51.

DRUSHTCHITZ, V.V. 1960. Aptichi, 307-308. In DRUSHTCHITZ, V.V \& KUDRJAVCEV, M.P. (eds) Atlas nizhnemelovoy fauny Severnogo Kavkaza i Kryma. Gostoptechizdat, Moskva.

EliÁŠ, M., MARTinEC, P., REHÁKOVÁ, D. \& VAŠ́íčEK, Z. 1996. Geologie a stratigrafie kurovických vápenců a tlumačovských slínovců v kurovickém lomu (svrchní jura, spodní křída, vnější Západní Karpaty, Česká republika). [Geology and stratigraphy of the Kurovice Limestone and Tlumačov Marl Formation at the Kurovice quarry (Upper Jurassic-Lower Cretaceous, Outer Western Carpathians, Czech Republic)]. Věstník Českého geologického ústavu 71, 259-275. [in Czech with English abstract]

ENGeSER, T. \& KeUPP, H. 2002. Phylogeny of the aptychi-possessing Neoammonoidea (Aptychophora nov., Cephalopoda). Lethaia 34, 79-96. DOI 10.1080/002411602317345894
FAVRE, E. 1880. Description des fossiles des couches tithoniques des Alpes fribourgeoises. Mémoires de la Société paléontologique Suisse 6, 1-74.

FAZZINI, P. 1965. Sulla presenza del Lamellaptychus angulocostatus Peters al tetto dei diaspri nei Monti di Poggiano presso Montepulciano (Siena). Atti della Società Naturale e Matematica di Modena 96, 20-26.

GÁSIOROWSKI, S.M. 1959. Succession of Aptychi Faunas in the Western Tethys during the Bajocian-Barremian Time. Bulletin de l'Académie polonaise des Sciences, Série des sciences de géologie et geographie 7(9), 715-722.

GĄSIOROWSKI, S.M. 1960. Remarques sur les Laevaptychi. Rocznik Polskiego towarzystwa geologicznego 30, 59-97.

GĄSIOROWSKI, S.M. 1962a. Sur les Aptychi a côtes. Rocznik Polskiego Towarzystwa geologicznego 32, 227-280.

GĄSIOROWSKI, S.M. 1962b. Aptychi from the Dogger, Malm and Neocomian in the Western Carpathians and their stratigraphical value. Studia geologica polonica 10, 1-144.

GIEBEL, C.G. 1852. Fauna der Vorwelt, Bd. 3, 1. Abth.: Cephalopoden. 765 pp. Leipzig.

GiLliÉRON, V. 1873. Apercu géologique sur les Alpes de Fribourg en général et description spéciale du Monsalvens. Materiaux pour la géologie de la Suisse 12, 1-232.

GLOCKER, E.F. 1841. Über den Jurakalk von Kurowitz in Mähren und über den darin vorkommenden Aptychus imbricatus. Verhandlungen der Kaiserlichen Leopoldinisch-Carolinischen Akademie der Naturforscher 19, 1-36.

GÜMBEL, C.W. 1861. Geognostische Beschreibung des bayerischen Alpengebirges und seines Vorlandes. XX +948 pp. Justus Perthes, Gotha.

HENNIG, E. 1914. Aptychen von den Cap Verdeschen Inseln. Zeitschrift der Deutschen geologischen Gesellschaft 65, 151-159.

Hoedemaeker, P.J., COMPANy, M.R. (reporters), AguirreUrReta, M.B., AVRaM, E., Bogdanova, T.N., Bujtor, L., Cecca, F., Delanoy, G., EtTachfini, M., Memmi, L., OWEN, H.G., RAWSON, P.F., SANDOVAL, J., TAVERA, J.M., Thieuloy, J.-P., TOVBINA, S.Z. \& VAŠÍČEK, Z. 1993. Ammonite zonation for the Lower Cretaceous of the Mediterranean region: basis for the stratigraphic correlation within IGCP Project 262. Revista Española de Paleontología 8, 117-120.

HoEdemaeker, P.J., Reboulet, S. (reporters), AguierRAUrreta, M.B., Alsen, P., Aoutem, M., Atrops, F., Barragan, R., Company, M., Gonzáles Arreola, C., Klein, J., Lukeneder, A., Ploch, I., Raisossadat, N., RAWSON, P.F., ROPOLO, P., VAŠÍČEK, Z, VERMEULEN, J. \& WIPPICH, M. 2003. Report on the $1^{\text {st }}$ International Workshop of the IUGS Lower Cretaceous Ammonite Working Group, the "Kilian Group" (Lyon, 11 July 2002). Cretaceous Research 24, 89-94 and erratum (p. 805).

HoUŠA, V. 1974. Los Apticos de Cuba I: Lamellaptychus angulocostatus (Pet.). Serie Geológica, Academia de Ciencias de Cuba 14, 1-57.

HoušA, V., Krs, M., KrsovÁ, M. \& PRUner, P. 1996. Magnetostratigraphic and micropaleontological investigations along the Jurassic/Cretaceous boundary strata, Brodno near Žilina (Western Slovakia). Geologica Carpathica 47(3), 135-151.

Houša, V., Krs, M., Krsová, M., Man, O., Pruner, P. \& VENHODOVÁ, D. 1999. High-resolution magnetostratigraphy 
and micropaleontology across the $\mathrm{J} / \mathrm{K}$ boundary strata at Brodno near Žilina, western Slovakia: summary and results. Cretaceous Research 20, 699-717. DOI 10.1006/cres.1999.0177

Houša, V., Krs, M., Man, O., Pruner, P., Venhodová, D., CeCCA, F., NARDI, G. \& Piscitello, M. 2004. Combined magnetostratigraphic, paleomagnetic and calpionellid investigations across Jurassic/Cretaceous boundary strata in the Bosso Valley, Umbria, central Italy. Cretaceous Research 25, 771-785. DOI 10.1016/j.cretres.2004.07.001

Houša, V., Pruner, P., ZaKharov, V. A., Kostak, M., Chadima, M., Rogov, M.A., ŠlechtA, S. \& MAZUCH, M. 2007. Boreal-Tethyan Correlation of the Jurassic-Cretaceous Boundary Interval by Magneto- and Biostratigraphy. Stratigraphy and Geological Correlation 15(3), 297-309.

DOI 10.1134/S0869593807030057

IMLAY, R.W. 1942. Late Jurassic fossils from Cuba and their economic significance. Bulletin of the Geological Society of America 53, 1417-1478.

JAKSCH, K. 1968. Aptychen aus dem Neokom zwischen Kaisergebirge und Saalach. Verhandlungen der Geologischen Bundesanstalt 1968, 105-124.

JAKSCH, K. 1996. Aptychen aus den Tithonprofilen von Achenkirch und Schwend (Tirol) mit Einbeziehung von Vergleichsexemplaren von den Ionischen Inseln. Jahrbuch der Geologischen Bundesanstalt 139, 453-466.

KASUMZADE, A.A. \& Rogov, M.A. 2006. Novye dannye o vozraste verchnojursko-nizhmelovoy karbonatnoy tolshchi vostochnoy chasti toragachaiskoy podzony geicha-akerinskoy ofiolitovoy zony Malogo Kavkaza, Azerbaijan. Journal “Knowledge", Physics, Mathematics, Earth Sciences 3, 72-83.

KÄLIN, O., PETACCA, E. \& RENZ, O. 1979. Jurassic pelagic deposits from southeastern Tuscany; aspects of sedimentation and new biostratigraphic data. Eclogae geologicae Helvetiae $72,715-762$.

KHALILOV, A.G. 1974. Aptichi Malogo Kavkaza, 92-175. In KHALILOV, A.G., AlIEV, G.A. \& ASKEROV, R.B. Nizhniy mel jugo-vostochnogo okonchaniya Malogo Kavkaza (stratigrafiya i paleogeografiya). Akademija nauk Azerbaijanskoi SSR, Baku.

KHALILOV, G.A. 1978. Nizhnemelovye aptichi Bolshogo Kavkaza (azerbaijanskaya chast). Izvestiya Akademii nauk Azerbaijanskoi SSR, Seriya Nauk o Zemle 5, 49-59.

Khalilov, A.G. 1988. Aptichi - Aptychus, 364-376. In Ali-ZAde, A.A., Aliev, G.A., Aliev, M.M., Alijula, C. \& KHALILOV, A.G. Melovaya fauna Azerbaijana. Elm, Baku.

KILIAN, W. 1910. Erste Abteilung- Unterkreide (Palaeocretacicum), Lieferung 2: Das bathyale Palaeocretacicum im südostlichen Frankreich; Valendis-Stufe, Hauterive-Stufe, Barreme-Stufe; Apt-Stufe, 169-288. In FRECH, F. Lethaea Geognostica, II, Mesozoikum, Band 3 (Kreide). Schweizerbart, Stuttgart.

KoENIGSWALD, G.H.R. 1939. Über einigen Ammoniten und Aptychen aus der unteren Kreide von Borneo. Jaarboek van het Mijnwezen in Nederlandsch Indië, Verhandlingen, 162-170.

Kozlova, N.V. \& ARKAdIEV, V.V. 1999. Aptichi titonberriaskikh otlozhenij Gornogo Kryma [Aptychuses from the Titon-Berriasian sediments of the Crimean Mountains].
Sbornik trudov molodykh učenykh Sankt-Petersburgkogo gornogo instituta 5, 19-23.

KoZlOVA, N.V. \& ARKADIEV, V.V. 2003. Titonskie-nizhnemelovye aptichi (Ammonoidea) Gornogo Kryma. Paleontologicheskiy Zhurnal 4, 36-44.

KRATOCHVÍLOVÁ, L. 2004. Spodnokřídové žebrované aptychyjejich klasifikace, fylogenetické vztahy a stratigrafické využití (vnějši a centrální Západni Karpaty a Severní vápencové Alpy). 155 pp. Thesis Ph.D., VŠB - Technická univerzita, Ostrava. [in Czech]

LAmAgnA, C.B. \& PINGUe, L. 1970. Stratigrafia e paleontologia della formazione degli scisti ad aptici dei dintorni di Bolognola (Macerata). 1) Studio sistematico e strutturale degli aptici giurassici. Bolletino della Società naturalisti di Napoli 78, 215-267.

MĚCHOVÁ, L., HOUŠA, V. \& VAŠ́́čEK, Z. 2008. Contribution to the systematics of Lower Cretaceous ribbed aptychi. Abstracts of $9^{\text {th }}$ Paleontological Conference, Warszava, 10-11 October 2008, 57-59.

MEYER, H. V. 1831. Das Genus Aptychus. Verhandlungen der Kaiserlichen Leopoldinisch-Carolinischen Akademie der Naturforscher 15, 125-170.

MichalíK, J., REHÁKOVÁ, D., HALÁSOVÁ, E. \& LiNTNEROVÁ, O. 2009. The Brodno section - a potentional stratotype of the Jurassic/Cretaceous boundary (Western Carpathians). Geologica Carpathica 60(3), 213-232. DOI 10.2478/v10096-009-0015-2

MICHALÍK, J., REHÁKOVÁ, D. \& VAŠ́ǐČEK, Z. 1995. Early Cretaceous changes in West-Carpathian area. Geologica Carpathica 46(5), 285-296.

MichalíK, J., VAŠÍČEK, Z. \& BORZA, V. 1990. Aptychy, tintinidy a stratigrafia hraničných jursko-kriedových súvrství v profile Strážovce (zliechovská jednotka krížňanského príkrovu, Strážovské vrchy, Centrálne Západné Karpaty). [Aptychi, tintinids and stratigraphy of the Jurassic/Cretaceous boundary beds in the Strážovce section (Zliechov Unit of the Krížna Nappe, Strážovské Vrchy Mts., Central Western Carpathians)]. Knihovnička Zemního plyna a nafty 9a, 69-92. [in Slovak with English summary]

MiCHALÍK, J., VAŠÍČEK, Z. \& BORZA, V. 1993. Biostratigrafia a mikrofácie vrchnojurskej a spodnokriedovej panvovej sekvencie v krížňanskom príkrove fatrika (profil Zrázy pri Dolnej Porube, Strážovské vrchy). [The Upper JurassicLower Cretaceous biostratigraphy and microfacies of a basin sequence in the Krížna Nappe of the Fatric]. Geologické práce, Správy 97, 105-112. [in Slovak with English summary]

MOORE, R.C. \& SYLVESTER-BRADLEY, P.C. 1957. Taxonomy and nomenclature of aptychi, L465-L471. In MOORE, R.C. (ed.) Treatise on invertebrate paleontology, Part L, Cephalopoda, Mollusca 4. Geological Society of America and University of Kansas Press, New York.

Nerodenko, V.V. \& Riabucha, V.T. 1987. Punktaptichi iz pograničnych otloženij jury i mela Gornogo Kryma. Visnyk Kijivskoho Universytetu, Serija Heolohii i Heohrafii 6, 23-28.

O'CONNELL, M. 1921. New species of ammonite opercula from the Mesozoic rocks of Cuba. American Museum Novitates 28, 1-15.

OGG, J.G. \& LOWRIE, W. 1986. Magnetostratigraphy of the Jurassic-Cretaceous boundary. Geology 14, 547-550. 
Ooster, W.A. 1857. Catalogue des Céphalopodes fossiles des Alpes suisses, II Partie: Céphalopodes d'ordres incertains. Nouveaux Mémoires de la Société helvétiques des sciences naturelles, 14-32.

OPPEL, A. 1863. Über jurassische Cephalopoden. Palaeontologische Mittheilungen aus dem Museum des Koeniglichen Bayerischen Staates 3, 127-266.

OPPEL, A. 1865. Die tithonische Etage. Zeitschrift der Deutschen geologischen Gesellschaft 17, 535-558.

PARKInSON, J. 1811. The Fossil Starfish, Echini, Shells, Insects, Amphibia, Mammalia \& $c$. The Organic Remains of a Former World 3. 479 pp. Sherwood, Neely, and Jones, London.

PATRULIUS, D. \& AVRAM, E. 1976. Les céphalopodes des cauches de Carhaga (Tithonique supérieur - Barrémien inférieur). Mémoires. Institut de Géologie et de Géophysique 24, 153-201.

PETERS, K. 1854. Die Aptychen der österreichischen Neocomien- und oberen Juraschichten. Jahrbuch der Kaiserlichköniglichen geologischen Reichsanstalt 5, 439-444.

PICTET, F.J. 1867. Etudes paléontologiques sur la faune à Terebratula diphyoides de Berrias (Ardèche). Mélanges paléontologiques 1, 43-131.

PiCTET, F.J. \& LORIOL, P. DE 1858. Description des fossiles contenus dans les terrains néocomiens des Voirons. Materiaux pour la paléontologie de la Suisse 2, 1-64.

PozZI, R. 1965. Studi geologici sulle isole del Dodecaneso (Mar Egeo). II. Nuova fauna ad aptici del malm dell' Isola di Rodi (Grecia). Rivista italiana di Paleontologia e Stratigrafia 71(3), 855-880.

PRUNER, P., HOUŠA, V., OlÓRIZ, F., KOŠŤÁK, M., KRS, M., MAN, O., Schnabl, P., Venhodová, D., TAVERA, J.M. \& MAZUCH, M. 2010. High-resolution magnetostratigraphy and biostratigraphic zonation of the Jurassic/Cretaceous boundary in the Puerto Escaño section (southern Spain). Cretaceous Research 31, 192-206.

PSZCZÓlKOWSKI, A. \& MYCZYŃSKI, R. 2004. Ammonite supported microfossil and nannoconid stratigraphy of the Tithonian-Hauterivian limestones in selected sections of the Branisko Succession, Pieniny Klippen Belt (Poland). Studia geologica polonica 123, 133-197.

QuENSTEDT, F.A. 1845-1849. Petrefaktenkunde Deutschlands. Erste Abteilung, erster Band. Die Cephalopoden. 580 pp. L.F. Fues, Tübingen.

RABRENOVIĆ, D. \& JANKIČEVIĆ, J. 1994. Otrivski kat sa cefalopodima na Grebenu kod Doneg Milanovca. Geološki anali Balkanskog Poluostrva 58, 83-100.

REBOUlET, S., KLEIN, J. (reporters), BARRAGÁN, R., COMPANY, M., GonZÁles-ARreola, C., LuKENEder, A., RAISOSSADAT, S.N., SANDOVAl, J., SZIVES, O., TAVERA, J.M., VAŠÍČEK, Z. \& VERMEULEN, J. 2009. Report on the $3^{\text {rd }}$ International Meeting of the IUGS Lower Cretaceous Ammonite Working Group, the "Kilian Group" (Vienna, Austria, 15 April 2008). Cretaceous Research 30(2009), 496-502. DO] 10.1016/j.cretres.2008.12.009

REBOUlet, S. \& RARD, A. 2008. Double alignments of ammonoid aptychi from the Lower Cretaceous of Southeast France: Result of a post-mortem transport or bromalites? Acta Palaeontologica Polonica 53, 261-274.

REHÁKOVÁ, D. 2000. Evolution and distribution of the Late Jurassic and Early Cretaceous calcareous dinoflagellates re- corded in the Western Carpathian pelagic carbonate facies. Mineralia Slovaca 32, 79-88.

REHÁKOVÁ, D. \& MICHALÍK, J. 1997. Evolution and distribution of calpionellids - the most characteristic constituents of Lower Cretaceous Tethyan microplankton. Cretaceous Research 18, 493-504. DOI 10.1006/cres.1997.0067

REHÁKOVÁ, D., ŠUlgan, F., VAŠíčEK, Z. \& MichalíK, J. 1995. Environment, fauna and paleogeographic importance of the Berriasian limestones from the Vigantice tectonic slice in the Outer Western Carpathians. Geologica Carpathica 46, 53-58.

REMANe, J., BAKAlOVA-IVANOVA, D., BorZA, K., KNAUER, J., NAGY, I., POP, G. \& TARDI-FILÁCZ, E. 1986. Agreement on the subdivision of the standard zones defined at the II $^{\text {nd }}$ Planctonic Conference, Roma 1970. Acta geologica Academiae Scientiarum Hungaricae 29, 5-14.

RENZ, O. 1972. Aptychi (Ammonoidea) from the Upper Jurassic and Lower Cretaceous of the western North Atlantic (Site 105, Leg 11, DSDP), 607-629. In HOLLISTER, C.D. \& EWING, J.I. Initial Reports of the Deep Sea Drilling Project 11.

RENZ, O. 1973. Two lamellaptychi (Ammonoidea) from the Magellan Rise in the Central Pacific, 895-898. In WINTERER, E.L. \& EwING, J.L. Initial Reports of the Deep Sea Drilling Project 17.

RENZ, O. 1977. Aptychi (Ammonoidea) from the Late Jurassic and Early Cretaceous of the Eastern Atlantic DSDP Site 367, 499-514. In LANCELOT, Y.\& SEIBOLD, E. Initial Reports of the Deep Sea Drilling Project 41.

RENZ, O. 1978. Aptychi (Ammonoidea) from the Early Cretaceous of the Blake-Bahama Basin, Leg 44, Hole 391C, DSDP, 899-909. In BENSON, W.E. \& SHERIDAN, R.E. Initial Reports of the Deep Sea Drilling Project 44.

RENZ, O. 1979a. Lower Cretaceous Ammonoidea from the northern Atlantic, Leg 47B, Hole 398D, DSDP), 361-369. In SIBUET, J.-C. \& RYAN, W.B.F. Initial Reports of the Deep Sea Drilling Project 47.

RENZ, O. 1979b. Aptychi (Ammonoidea) and ammonites from the Lower Cretaceous of the western Bermuda Rise, Leg 43, Site 387, DSDP, 591-596. In TUCHOLKE, B.E. \& VoGT, P.R. Initial Reports of the Deep Sea Drilling Project 43.

RENZ, O. 1983. Early Cretaceous cephalopoda from the BlakeBahama Basin (Deep Sea Drilling Project Leg 76, Hole 534A) and their correlation in the Atlantic and southwestern Tethys, 639-644. In SHERIDAN, R.E. \& GRANDSTEIN, F.M. Initial Reports of the Deep Sea Drilling Project 76.

RENZ, O. \& HABICHT, K. 1985. A correlation of the Tethys Maiolica Formation of the Breggia section (southern Switzerland) with Early Cretaceous coccolith oozes of Site 534A, DSDP Leg 76 in the western Atlantic. Eclogae geologicae Helvetiae 78, 383-431.

SCHAFHÄUTL, K.E. 1853. Über die geognostischen Horizonte in den Bayerischen Voralpen. Neues Jahrbuch für Mineralogie, Geognosie, Geologie und Petrefactenkunde 1853, 399-432.

SCHINDEWOLF, O.H. 1958. Über Aptychen (Ammonoidea). Palaeontographica, Abteilung A 111, 1-46.

StefanOV, J. 1961. Amonitni operkulumi (aptichi) ot dolnata kreda na Bălgarija. [Ammonoid operculums (aptychi) from the Lower Cretaceous of Bulgaria]. Trudove Vrchu Geologijata na Bălgarija, Serija Paleontologija, Stratigrafija $i$ Tektonika 3, 209-235. [in Bulgarian with English summary] 
STOPPANI, A. 1881. Paléontologie Lombarde ou Description des fossiles de Lombardie (4e Série). Aptychus, 111-127. In MeneGhinI, J. (1867-1881) Monographie des fossiles du calcaire rouge ammonitique (Lias supérieur) de Lombardie et de l'Apennin central. Milano.

THOMPSON, M.R.A. 1972. Lower Cretaceous Lamellaptychus (Aptychi, Ammonoidea) from the south-eastern Alexander Island. Bulletin of British Antartic Survey 30, 35-40.

TrauTH, F. 1927. Aptychenstudien I. Über die Aptychen im Allgemeinen. Annalen des Naturhistorischen Museums in Wien 41, 171-259.

TrAUTH, F. 1928. Aptychenstudien II. Die Aptychen der Oberkreide. Annalen des Naturhistorischen Museums in Wien 42, 122-193.

Trauth, F. 1930. Aptychenstudien III. Nachtrag zu den „Aptychen im Allgemeinen“. Annallen des Naturhistorischen Museums in Wien 44, 330-338.

TrAUTH, F. 1931. Aptychenstudien VI. Zweiter Nachtrag zu den „Aptychen im Allgemeinen“. Annalen des Naturhistorischen Museums in Wien 45, 18-21.

Trauth, F. 1935. Die Punctaptychi des Oberjura und der Unterkreide. Jahrbuch der Geologischen Bundesanstalt 85, 309-332.

TRAUTH, F. 1936. Über Aptychenfunde auf Cuba. Proceedings Koninklijke nederlandse Academie van Wetenschappen, Series Sciences B, Amsterdam 39(1), 66-76.

Trauth, F. 1938. Die Lamellaptychi des Oberjura und der Unterkreide. Palaeontographica, Abteilung A 88, 118-240.

Tremolada, F., Bornemann, A., Bralower, T., Koeberl, C. \& VAN DE SCHOOTBRUGGe, B. 2006. Paleooceanographic changes across the Jurassic/Cretaceous boundary: the calcareous phytoplankton response. Earth and Planetary Science Letters 241, 361-371. DO1 10.1016/j.eps1.2005.11.047

TuRCULET, I. 1964. „Stratele cu Aptychus“ din Chiuveta mezozoica a Raraului (Carpatii Orientali). Analele stiintifice ale Universitătii “Al. I. Cuza” din Iași, Seria noua, Secț. II b, 10, 45-70.

TURCULET, I. 1971. Cercetari geologice asupra depozitelor Jurasice si Eocretacice din cuveta Rarău-Breaza. Studii tehnice și ekonomice, Serie J. Stratigrafie. Institutul geologic $10,1-141$.

TURCULET, I. 1994. Asupra oportunitătii separării de parasubgenuri în cadrul paragenului Lamellaptychus (Cephalopoda, Ammonoidea). Studii și Cercetări de Geologie, Geofizică, Geografie, Serie Geologica 39, 119-126.

TURCUlET, I. \& AVRAM, E. 1995. Lower Cretaceous aptychus assemblages in Rumania. 1) Svinita Region (SW Rumania). Analele stiintifice ale Universitătii “Al. I. Cuza” din Iași, Ser. noua, Secț. II b, 40-41(1994-1995), 87-112.

VAŠÍČEK, Z. 1974. Zpráva o makropaleontologickém výzkumu slezské jednotky za rok 1971. [Bericht über makropaläontologische Untersuchungen in der Schlesischen Einheit im Jahre 1971]. Sborník vědeckých prací Vysoké školy báňské, Řada hornicko-geologická 18(1972), 97-115. [in Czech with German summary]

VAŠÍČEK, Z. 1977. Hukvaldy - die neue makrofaunistische Lokalität der Schlesischen Einheit (Hauterive). Časopis Slezského muzea, Série A 26, 129-136.
VAŠ́́ČEK, Z. 1984. K distribuci hlavonožců v pelagických uloženinách spodní křídy na Strážovské pahorkatině. Sborník konference „Paleoekologie“, 132-136. Brno. [in Czech]

VAŠÍČEK, Z. 1996. Aptychi and stratigraphy of the Lower Cretaceous in the Western Carpathians. Mitteilungen. Geologischpaläontologisches Institut der Universität Hamburg 77, 221-241.

VAŠÍČEK, Z. \& FAUPL, P. 1996. Die Cephalopoden aus den Rossfeldschichten der Reichraminger Decke (Obervalanginium, oberösterreichische Kalkalpen). Jahrbuch der Geologischen Bundesanstalt 139(1), 101-125.

VAŠÍČEK, Z. \& FAUPL, P. 1998. Late Valanginian cephalopods in relation to the palaeogeographic position of the Rossfeld and Schrambach Formation of the Reichraming Nappe (Northern Calcareous Alps, Upper Austria). Zentralblatt für Geologie und Paläontologie, Teil I, 11/12, 1421-1432.

VAŠÍČEK, Z. \& FAUPL, P. 2000. Zur Biostratigraphie der Schrambachschichten in der Reichraminger Decke (Unterkreide, oberösterreichische Kalkalpen). Abhandlungen der Geologischen Bundesanstalt 56(1999), 593-624.

VAŠÍČEK, Z. \& HOEDEMAEKER, P.J. 1997. Aptychi from the Lower Cretaceous strata along the Río Argos (Caravaca, SE Spain). Scripta Geologica (Leiden) 115, 29-46.

VAŠÍČEK, Z. \& MiCHALÍK, J. 1995. The last lamellaptychi in the Hauterivian sequence of the Krížna Nappe, Central Western Carpathians. Geologica Carpathica 46, 303-310.

VAŠÍČEK, Z., MiCHALÍK, J. \& REHÁKOVÁ, D. 1994. Early Cretaceous stratigraphy, palaeogeography and life in Western Carpathians. Beringeria, Würzburger geowissenschaftliche Mitteilungen 10, 1-170.

VAŠ́́ČEK, Z., RABRENOVIĆ, D., RADULOVIĆ, V. \& RADULOVIĆ, B. 2009. Late Valanginian-Hauterivian cephalopod fauna from the Stara Planina Mountain (eastern Serbia). Neues Jahrbuch für Geologie und Paläontologie, Abhandlungen 251(2), 129-145. DOI 10.1127/0077-7749/2009/0251-0129

VAŠÍČEK, Z., REHÁKOVÁ, D. \& FAUPL, P. 2000. Zur Biostratigraphie der Schrambachschichten der Oisbergmulde bei Hollenstein a.d. Ybbs (Lunzer Decke, Kalkalpen, Niederösterreich). Abhandlungen der Geologischen Bundesanstalt 56(1999), 625-650.

VAŠíčEK, Z., REHÁKOVÁ, D., MichalíK, J., PETERČÁKOVÁ, M. \& HALÁSOVÁ, E. 1992. Ammonites, aptychi, nanno- and microplancton from the Lower Cretaceous Pieniny Formation in the "Kysuca Gate" near Žilina (Western Carpathian Klippen Belt, Kysuca Unit). Západné Karpaty, Séria Paleontológia 16, 43-56.

VolTZ, P.L. 1837. Zweiter Vortrag über das Genus Aptychus. Neues Jahrbuch für Mineralogie, 432-438.

WINKLER, G.G. 1868. Versteinerungen aus dem bayerischen Alpengebiet mit geognostischen Erläuterungen. I. Die Neocomformation des Urschlauerachenthales bei Traunstein mit Rücksicht auf ihre Grenzschichten. 48 pp. München.

ZITTEL, K.A. 1868. Palaeontologische Studien ueber die Grenzschichten der Jura- und Kreide-Formation im Gebiete der Karpathen, Alpen und Apenninen. I. Abtheilung. Die Cephalopoden der Stramberger Schichten, 1-118. In OPPEL, A. \& ZITTEL, K.A. (eds) Palaeontologische Mittheilungen aus dem Museum des koeniglichen Bayerischen Staates 2. Stuttgart. 